\title{
'With sound of lute and pleasing words': The Lute Song and Voice Types in Late Sixteenth- and Early Seventeenth-Century England
}

\author{
Richard Robinson \\ Email: ra_robinson81@hotmail.com
}

\begin{abstract}
The Elizabethan and Jacobean lute song (1597-1622) represents one of the most iconic genres of all early music. Although much literature has been dedicated to this repertory, the issue of the voices for which this music was probably intended still remains surprisingly underexplored. This subject has, moreover, acquired greater significance in light of research undertaken by Simon Ravens (2014) and Andrew Parrott (2015), which has challenged the plausibility of the falsetto voice in Medieval and Renaissance Europe, particularly in sacred music.

This paper explores the issue of the types of voices that most likely performed the Elizabethan and Jacobean lute song in three ways. Firstly, contemporary English evidence for lutes and viols is analyzed together with information regarding tuning and transposition. Secondly, the music itself is investigated, including the part names and clefs used alongside the tessitura of the melodic line. Finally, a detailed examination of evidence for the tenor and falsetto voice is presented, including a critical examination of the word 'faine' (usually assumed to mean 'falsetto'). The collective results are then brought together to refine current ideas regarding the voices used in the Elizabethan and Jacobean lute song.
\end{abstract}

'... Dowland to thee is deere, whose heauenly tuch

Vpon the Lute, dooth rauish humane sense:

Spenser to me, whose deepe Conceit is such,

As passing all conceit, needs no defence.

Thou lou'st to heare the sweet melodious sound,

That Phoebus Lute (the Queene of Musicke) makes:

And I in deepe Delight am chiefly drownd,

When as himselfe to singing he betakes ... '1

'VVHilst vitall sapp did make me spring, And leafe and bough did flourish brave,

I then was dumbe and could not sing, Ne had the voice which now I have:

But when the axe my life did end, The Muses nine this voice did send'. ${ }^{2}$

\footnotetext{
${ }^{\mathbf{1}}$ See Appendix 2 doc. 19.

${ }^{2}$ Edmund Spenser, 'Verses upon the said Earles Lute' ['Richard Earle of Corke'], Tvvo Histories of Ireland, ed. Sir James Ware (Society of Stationers, Dublin, 1633), sig. L4 . 
Towards the centre of a small anthology of 20 poems about love, published in 1599 and attributed on its title page to none other than William Shakespeare (1564-1616), ${ }^{3}$ a verse is found which meditates briefly on the interrelationship between 'Musicke and sweet Poetrie' (see the first of the above extracts). Paying homage in its 14 lines to two celebrities of the Elizabethan musical and literary worlds - John Dowland (1563-1626) and Edmund Spenser (1552-99) - and simultaneously reflecting on the close marriage between poetry, singing, and the lute, there can surely be no clearer symbol of the status which this musical combination had attained by $c .1600$. By this time, the lute had also cemented its reputation as the 'Queene of Musicke': it was mentioned in countless contemporary texts, often linked to famous musical figures from antiquity like Amphion and Apollo, and it was even sometimes described in a quasireligious manner (as a former tree that had acquired a divinely bestowed musical voice in its 'afterlife', like in the second extract above by Spenser). Indeed, over the 25-year period of its peak (1597-1622), some 30 different lute song collections appeared in print, amounting to a total of more than 600 songs. ${ }^{4}$ After eventually falling out of fashion by the 1630s, this repertory was once again brought to public attention by Edmund Fellowes (1870-1951), whose editions of The English School of Lutenist SongWriters from the 1920s onwards provided the impetus for further scholarly research and helped secure the lute song's continued presence in modern times, both in commercial recordings and the popular imagination at large. ${ }^{5}$

Yet despite the wealth of scholarship dedicated to this repertory, the types of voices for which it was probably intended has received surprisingly little attention to date. ${ }^{6}$ In some respects, this may seem inevitable, since any attempt to establish precise parameters is confronted by the truism that no Elizabethan or Jacobean voices survive and also, as the influential French writer Pierre de La Primaudaye (1546-1619) observed, 'we seldome see that the speaking and singing of one resembleth the speech and tune of another'. ${ }^{7}$ Furthermore, singing was a social phenomenon that traversed all strata of English society, and evidence for lute accompaniment occurs quite frequently within this complex web of singing practices, both in amateur and professional music-making. ${ }^{8}$ Indeed, the earliest surviving English lute music, such as Royal Appendix 58 (after 1551) and Stowe 389 (1558), both held in the British Library, shows a strong connection to the voice via tablature accompaniments to popular songs and solo versions based on them. ${ }^{9}$

The general lack of scholarly interest in the voice types associated with the Elizabethan and Jacobean lute song has nonetheless acquired fresh significance in light of recent research challenging the plausibility of the falsetto voice in this period. In 2015, for example, Andrew Parrott re-examined evidence previously assumed to document the countertenor or falsetto voice in fifteenth- and sixteenth-

\footnotetext{
${ }^{3}$ This collection is generally accepted to contain pirated texts, with only five poems in the collection securely linked to Shakespeare. The poem in question (no. 8) is thought to be by Richard Barnfield (1574-1627); see Colin Burrow, ed., The Oxford Shakespeare: The Complete Sonnets and Poems (Oxford: Oxford University Press, 2002), 74-82.

${ }^{4}$ For a complete list, see Matthew Spring, The Lute in Britain: A History of the Instrument and its Music (Oxford: Oxford University Press, 2001), 266-7.

${ }^{5}$ See Edmund H. Fellowes, The English School of Lutenist Song Writers, series 1, 16 vols. (London: Stainer \& Bell, 1920-32), series 2, 16 vols. (London: Stainer \& Bell, 1925-7), rev. R. Thurston Dart, et al., The English Lute-Songs (London: Stainer \& Bell, 1959-). New recordings and reissues of lute song recordings are released almost annually; see www.amazon.co.uk. For examples of the lute song in popular imagination, see Winston Graham, The Grove of Eagles: A Novel of Elizabethan England (London: Pan Books, 1963/2016), 366 and 571-2, and Philip K. Dick, Flow My Tears, the Policeman Said (Boston: Mariner Books, 1974/ 2012), $110-11$ and 242 .

${ }^{6}$ The fullest investigation into this area remains Edward Huws Jones, The Performance of English Song 1610-1670 (New York and London: Garland Publishing, 1989), 25-47.

${ }^{7}$ Peter (= Pierre) de La Primaudaye, The French Academie, trans. Thomas Bowes (London: Edmund Bollifant, 1586$), 22$. Michael Praetorius, Syntagma Musicum (Wolfenbüttel, 1619), ed. W. Gurlitt, facs. edn (Kassel: Bärenreiter, 1958), ii, 17-18, noted, after showing how high and low various voices could safely go ('ohn gefehr'), that no firm conclusions could be reached nor strict limits imposed ('Wiewol hierin nichts gewisses zu schliessen oder in gewisse terminos zu bringen').

${ }^{8}$ Adam Fox, Oral and Literate Culture in England, 1500-1700 (Oxford: Oxford University Press, 2000/2003), 27-31, 41-4; and Christopher Marsh, Music and Society in Early Modern England (Cambridge: Cambridge University Press, 2010), $20-1$.

'John Ward, 'The Lute Music of MS Royal Appendix 58', Journal of the American Musicological Society, 13 (1960), 117-25.
} 
century sacred vocal music, concluding that terms like 'fausset' or 'falsetum' had been misunderstood and that modern vocal pitch had also fuelled misinterpretation of the notation. ${ }^{10}$ In the previous year, Simon Ravens published a chronological investigation of the falsetto voice (from the Ancient Greeks through to the twentieth century) that also considered aspects like human physiology alongside national and cultural vocal stereotyping. As a result of these independent publications, both scholars concluded that falsetto singing seems not really to have been used in Medieval and Renaissance vocal music. ${ }^{11}$

Yet in spite of this, the idea persists that the lute song was 'composed in the style of the professional, courtly, countertenor male voice', which was 'fashionable throughout the period and commonly developed among male vocalists'. ${ }^{12}$ Focussing primarily on the printed lute song collections alongside relevant literary, archival, and iconographical evidence, this article will therefore attempt to refine current knowledge of the performance of this repertory via consideration of the following: (a) an investigation into the instruments used, their tunings, and evidence for transposition; (b) an analysis of the music itself, including the part names, clefs, and melodic writing; and finally (c) an examination of literary, documentary, and musical evidence for the tenor and the falsetto voice and their respective connections to the lute song. The combination of these different research areas collectively indicates that this repertory was primarily conceived for instruments in fixed tunings, with women and children singing the song melodies in the written treble register and men singing them in the octave below in tenor register.

\section{Instruments and Tunings}

Before discussing information relating to singing in late Tudor and early Stuart England, it is worth clarifying the instrument(s) which accompanied the lute song. The title pages and music of the printed collections indicate several possible performing forces, including multiple singers (up to six voices), tablature for lute or orpharion, and additional or substitutional bass viol or lyra viol (or occasionally 'viols'). Two further printed music books with tablature add six more songs: four with bandora and two with cittern accompaniment (see Table 1). ${ }^{13}$

A careful examination of the lute tablature reveals that it is primarily intended for the 'meane lute' in $\mathrm{g}^{\prime}$, tuned $\mathrm{g}^{\prime}-\mathrm{d}^{\prime}-\mathrm{a}-\mathrm{f}-\mathrm{c}-\mathrm{G}$ (Image 1a to $1 \mathrm{c}$ ). Since the orpharion (Image 2 ) had identical tuning to a mean lute and could thus read the same tablature without affecting the pitch of the voice and viol parts, it is unsurprising that it also appears on certain songbooks as a suggested substitute for the lute. ${ }^{14}$ Although largely ignored in modern lute song performances, the orpharion may actually have been the preferred choice of accompaniment for some contemporaries; for example, John Aubrey (1626-97) posthumously recorded his grandfather's praise for Sir Carew Raleigh (c.1550-c.1625), who apparently 'had a delicate cleare voice, and played singularly well on the olpharion (which was the instrument in fashion in those

\footnotetext{
${ }^{10}$ Andrew Parrott, 'Falsetto Beliefs: The “Countertenor” Cross-Examined', Early Music, 43 (2015), 79-110.

${ }^{11}$ Simon Ravens, The Supernatural Voice: A History of High Male Singing (Woodbridge: Boydell Press, 2014). Both scholars have expressed doubts about the falsetto voice for some time; see Parrott's correspondence, 'False Voices', Early Music, 9 (1981), 71-5 (p. 72); Ravens, 'A Sweet Shrill Voice: The Countertenor and Vocal Scoring in Tudor England', Early Music, 26 (1998), 122-34; and Ravens, 'Countertenor Counterblast', Early Music, 28 (2000), 507-8.

${ }^{12}$ Scott A. Trudell, 'Performing Women in English Books of Ayres', Gender and Song in Early Modern England, ed. Leslie C. Dunn and Katherine R. Larson (Farnham: Ashgate Publishing, Surrey, 2014), 15-29 (pp. 21, 24). This viewpoint has undoubtedly been influenced by the legacy of Alfred Deller (1912-1979) and Russell Oberlin (1928-2016), alongside the continued popularity of the countertenor voice in commercial recordings of this repertory. For a recent example of the opinion that 'Dowland lute songs' are 'monopolised by Oxbridgey countertenors', see Richard Bratby, Opera Review: 'Ambassador, you are really spoiling us', The Spectator Christmas Special (19 December 2020-2 January 2021), 93-4 (at 94).

${ }^{13}$ William Barley, A Nevv Booke of Tabliture (London: William Barley, 1596), iii (bandora), sig. C2 $2^{\mathrm{v}}-\mathrm{D} 2{ }^{\mathrm{r}}$ (4 songs); Thomas Robinson, New Citharen Lessons, With Perfect Tunings of the Same, from Foure Course of Strings to Fourteene Course (London: William Barley, 1609), nos. 46 and 47.

${ }^{14}$ Barley, A New Booke of Tabliture, ii (orpharion), sig. $\mathrm{a} 4^{\mathrm{r}}$ actually states explicitly that music 'played vpon the Lute may as well be plaied vpon the Orpharion'.
} 
Table 1. Instrumentation in the Printed Song Collections with Tablature

\begin{tabular}{|c|c|}
\hline $\begin{array}{l}\text { Instruments named to accompany } \\
\text { songs with tablature }{ }^{a}\end{array}$ & Printed song collections with tablature $\left(1596^{\mathrm{b}}-1622\right)$ \\
\hline Lute & $\begin{array}{l}\text { Dowland i (1597); Morley Canzonets (1597) }{ }^{\text {c }} \text { Cavendish (1598); Morley i (1600); } \\
\text { Dowland ii (1600); Jones i (1600); Rosseter/Campion (1601); Jones ii (1601); } \\
\text { Dowland iii (1603); Greaves (1604); Pilkington (1605); Jones Vltmvm Vale [= iii] } \\
\text { (1605); Hume i (1605); Danyel (1606); Coprario Fvneral Teares (1606); Bartlet } \\
\text { (1606); Campion Lord Hayes (1607) ; Ford (1607); Jones iv (1609); Corkine } \\
\text { (1610); Jones v (1610); Maynard (1612); Corkine ii (1612); Dowland Pilgrimes } \\
\text { Solace (1612); Campion i \& ii (? 1613); Coprario Songs of Mourning (1613); } \\
\text { Campion Somerset (1614); Campion iii \& iv (c.1618); Attey (1622) }\end{array}$ \\
\hline Orpharion & $\begin{array}{l}\text { Dowland i (1597); Dowland ii (1600); Jones i (1600); Rosseter/Campion (1601); } \\
\text { Dowland iii (1603); Pilkington (1605); Bartlet (1606); Ford (1607); Hume } \\
\text { Poeticall Musicke (1607); Campion iii \& iv (c.1618) }\end{array}$ \\
\hline Cittern & Robinson (1609) \\
\hline Bandora & Barley (1596) \\
\hline Bass lute & Dowland iii (1603); Danyel $(1606)^{\mathrm{c}}$ \\
\hline Bass viol/'Viol de gambo' & $\begin{array}{l}\text { Dowland i (1597); Cavendish (1598); Morley i (1600); Dowland ii (1600); Jones i } \\
\text { (1600); Rosseter/Campion (1601); Jones ii (1601); Dowland iii (1603) }{ }^{\mathrm{d}} \text {; Greaves } \\
\text { (1604); Pilkington (1605); Jones Vltmvm Vale [=iii] (1605); Hume i (1605); Danyel } \\
\text { (1606); Coprario Fvneral Teares (1606); Bartlet (1606); Campion Lord Hayes } \\
\text { (1607); Ford (1607); Hume Poeticall Musicke (1607); Jones iv (1609); Corkine } \\
\text { (1610); Jones v (1610); Maynard (1612); Corkine ii (1612); Dowland Pilgrimes } \\
\text { Solace (1612) }{ }^{\text {d }} \text { Campion i \& ii (? 1613) } \text {; Coprario Songs of Mourning (1613); } \\
\text { Campion Somerset (1614); Campion iii \& iv (c.1618); Attey (1622) }\end{array}$ \\
\hline Lyra viol & Jones ii (1601) \\
\hline No instrument specified & Ferrabosco (1609); Robert Dowland (1610); Mason and Earsden (1618) \\
\hline
\end{tabular}

Note. The number after the composer's name indicates the relevant songbook (i.e. 'Dowland i' = John Dowland, The First Booke of Songes). This Table excludes Richard Allison, The Psalmes of Dauid in Meter (London: William Barley, 1599) and Robert Tailour, Sacred Hymns Consisting of Fifti Select Psalms of David and Others (London: Thomas Snodham, 1615), since these are not, strictly speaking, collections of lute ayres, even though they were also printed with tablature.

anstrumentation listed relates only to the songs with tablature included in these collections; i.e. it excludes other pieces that some of these books also contain, such as unaccompanied madrigals, songs with viol consort, instrumental pieces, etc.

${ }^{\mathrm{b}}$ The table includes the songs with bandora in William Barley, A Nevv Booke of Tabliture, iii (bandora), hence why it starts a year before the first printed collection of lute songs.

'Where instruments are named in the music, internal title page or preface (rather than on the main title page)

${ }^{\mathrm{d}}$ Title pages of songbooks that specify 'viols' in the plural.

dayes), to which he did sing. ${ }^{15}$ Yet could these songs have been accompanied by differently tuned lutes as well?

A bass lute in $\mathrm{d}^{\prime}$, tuned $\mathrm{d}^{\prime}$-a-e-c-G-D, could theoretically have been used instead of a mean lute to suit a lower voice, although this was surely not 'common practice'. ${ }^{16}$ Bass lutes are in fact explicitly named only very rarely in surviving English nobles' and gentries' wills and inventories of the period (see Appendix 1a). Collectively, the largest proportion of this information shows typical ownership of only one lute, whilst references that do not follow this trend normally document ownership of only small numbers, that is, between 'ij Lutes' and ' 4 lootes'. Clearly, multiples on their own cannot be assumed to indicate contrasting sizes and tunings, irrespective of the possibility that they may have differed from one another in reality - a point which can be usefully emphasized via comparison with other instruments

\footnotetext{
${ }^{15}$ Andrew Clark, ed., 'Brief Lives', Chiefly of Contemporaries, Set Down by John Aubrey, Between the Years 1669 \& 1696 (Oxford: Clarendon Press, 1898), ii, 179. See also The Private Life of an Elizabethan Lady: The Diary of Lady Margaret Hoby, 1599-1605, ed. Joanna Moody (Stroud: Sutton Publishing, 1998), 56 (entry for 26 January 1600).

${ }^{16}$ As claimed by Paul O’Dette, 'The Lute', A Performer's Guide to Renaissance Music, ed. Jeffery Kite-Powell (Bloomington: Indiana University Press, 1991/2007), 170-86 (p. 172).
} 


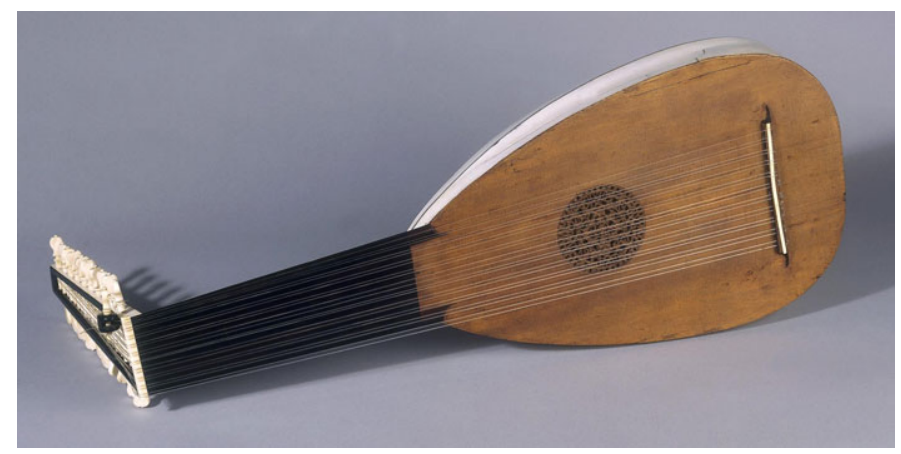

Image 1a. Anonymous Italian (?Venice) (c. 1630), 11-course Lute with ebony and ivory inlay (Museum No. 1125-1869) (๔ The Victoria and Albert Museum (V\&A), London, with permission). No English lutes survive from the period.

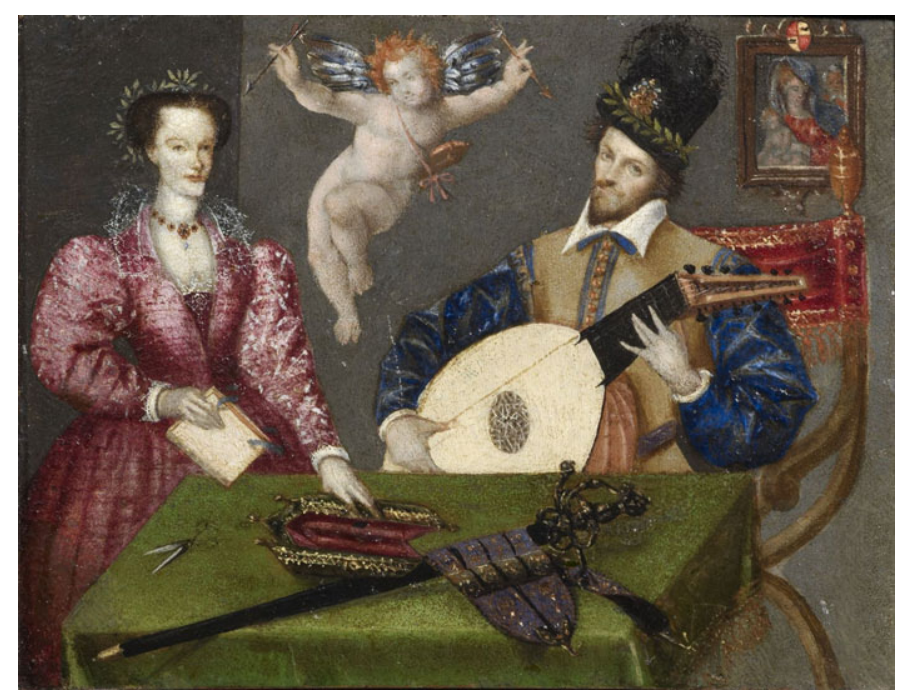

Image 1b. Anonymous English or Northern Italian (c.1590-1600), Betrothal painting on a copper panel (๔) Derek Johns Private Collection, with permission).

where variations in sizes and tunings seem unlikely, such as the 'iij lutes' with the 'iij bandoraes' in Robert Dudley, Earl of Leicester's (1532-88) inventory at Kenilworth Castle in Warwickshire (c.1578) or the 'Lutes viii' with the 'Vyrgynalles paires v' in the inventories (1596-1609) of John Lumley, First Baron Lumley (c.1533-1609) at his various residences in Surrey, County Durham, and London. ${ }^{17}$

Similarly, with virtually no exceptions, ${ }^{18}$ listings that mention lutes alongside songbooks or other 'lewting books' provide no details regarding the instrument's size and most likely relate to typical (i.e. 'meane') lutes, like the 1608 will of Godwin Walsall, Hebrew lecturer at Corpus Christi College,

\footnotetext{
${ }^{17}$ British Library, Add. MS 78176, fol.42r ; and Lionel Cust, 'The Lumley Inventories', Walpole Society, 6 (1918), 15-35 (p. 29).

${ }^{18}$ The oft-cited 1603 inventory of Sir Thomas Kytson (1540-1602) at Hengrave Hall in Suffolk precisely lists four lutes in three sizes (see Appendix 1a) alongside several songbooks, but this represents a rare exception and it is going too far to assume that 'similar collections [...] must have existed in other households of similar status', particularly regarding different sizes and tunings of lutes; see Hector Sequera, 'Practice and Dissemination of Music in the Catholic Network as Suggested by the Music Collection of Edward Paston (1550-1630) and Other Contemporary Sources', Networks of Music and Culture in the Late Sixteenth and Early Seventeenth Centuries: A Collection of Essays in Celebration of Peter Philips's $450^{\text {th }}$ Anniversary, ed. David J. Smith and Rachelle Taylor (London: Routledge, 2013/2016), 215-30 (p. 223).
} 


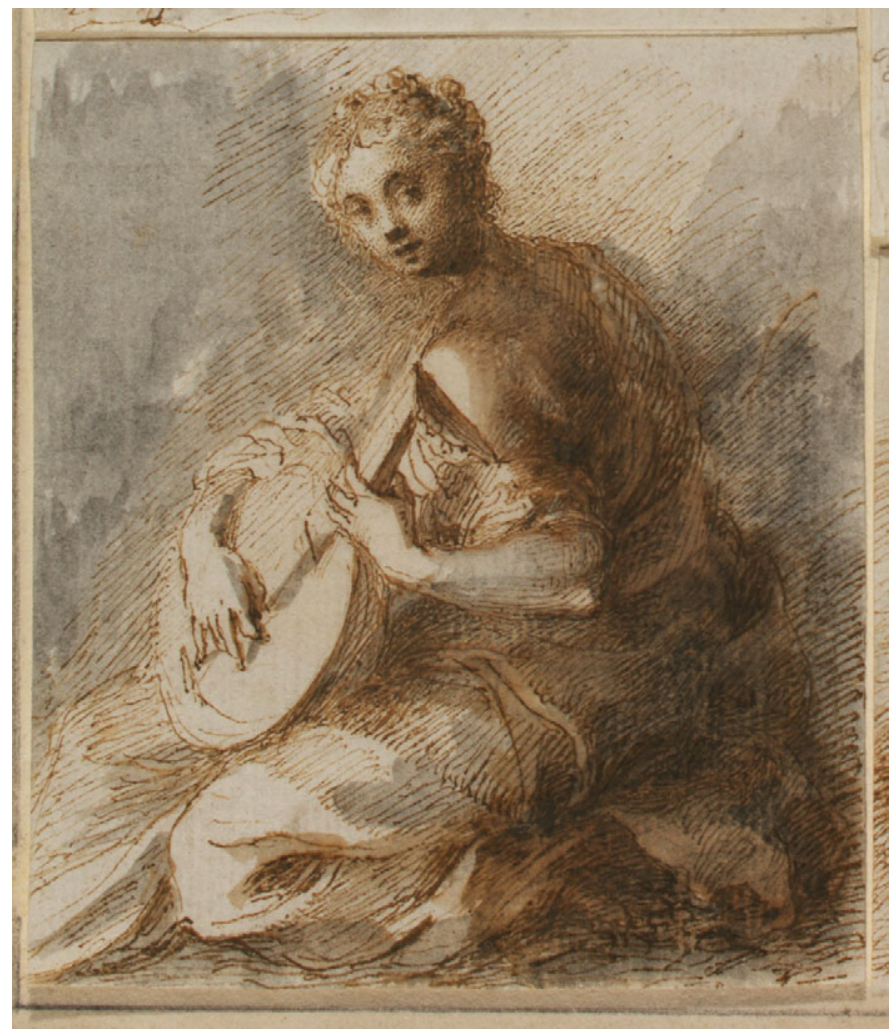

Image 1c. Isaac Oliver (c.1565-1617), Female figure playing a lute (c.1610), ink drawing, The Courtauld, London (Samuel Courtauld Trust) (@ The Courtauld, with permission).

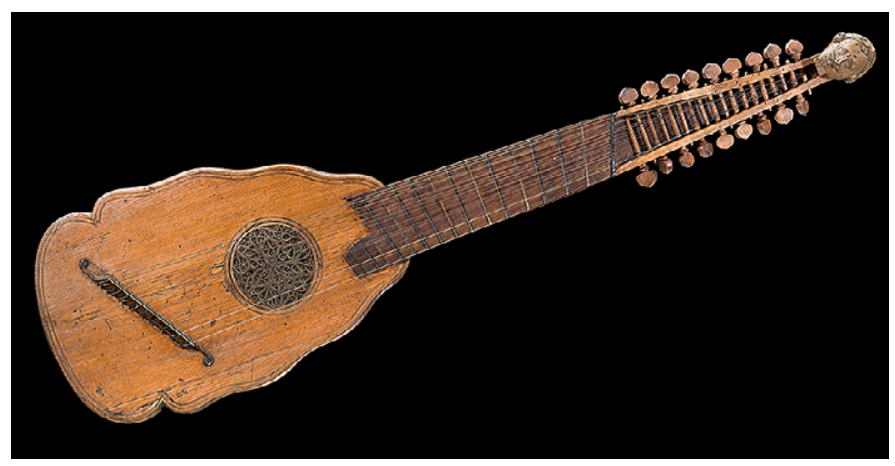

Image 2. Francis Palmer (London, 1617), Orpharion, Collection of Musikmuseet, Musikhistorisk Museum \& Carl Claudius' Samling, Copenhagen, Denmark Inv. No. CL 139 (৫ Arnold Mikkelsen, CC-BY-SA, The Danish Music Museum / The National Museum of Denmark, with permission).

Cambridge University, which simply records 'a lute \& a lute case' alongside 'Dowlandes songes in 2 volumes. sticht' and 'benetes songes in 4 . partes. $4^{\mathrm{o}}$ sticht'. ${ }^{19}$ In addition, only a miniscule number of literary sources connect the bass lute to solo song, and no English iconography convincingly substantiates

\footnotetext{
${ }^{19}$ See Elisabeth Leedham-Green, Books in Cambridge Inventories: Booklists from Vice-Chancellor's Court Probate Inventories in the Tudor and Stuart Periods (Cambridge: Cambridge University Press, 1986), i, 559 and ii, 826.
} 
this practice. ${ }^{20}$ It seems that the bass lute was primarily used in lute consorts, like 'the three lutes' at court in which Robert Johnson (c.1583-1633) and Philip Rosseter (1568-1623) both variously played bass lute (see Appendix 1b), and in larger ensembles with other instruments, like those heard in the 1607 'Maske' in honour of the marriage of Sir James Hay (c.1580-1636), First Earl of Carlisle to Honoria Denny, daughter of the Earl of Norwich. ${ }^{21}$ Indeed, printed lute songs which explicitly stipulate a 'base lute' are exceptionally rare (just two out of more than 600 songs). ${ }^{22}$

This situation is also similar for lutes in other tunings and sizes. Although other lute tunings existed on the Continent, ${ }^{23}$ it is clear that, for contemporary English lutenists with any knowledge of musical notation and theory beyond tablature, the term 'lute' generally indicated an instrument with the top string solmised as $g$ sol re $u t .{ }^{24}$ In turn, the word 'meane' generally appears only where it was necessary to distinguish it from the 'base' lute. ${ }^{25}$ These observations are confirmed by analysis of other contemporary English lute music, such as the surviving corpus of lute duets (c.1570-1610), which are almost always for 'two Lutes tun'd alike', ${ }^{26}$ save a small number for mean and bass lutes (i.e. tuned a fourth apart) and a tiny handful of Continental pieces for two lutes tuned a tone apart, mostly copied from prints of Pierre Phalèse (1510-73). ${ }^{27}$ Similarly, despite its misleading name, the 'treble lute' in the English mixed-consort music of Thomas Morley (1557/8-1602) and Rosseter was actually intended for a mean lute in $\mathrm{g}^{\prime}$ ('treble' perhaps simply hinted at the way its part was dominated by high fret positions, often on the treble string). ${ }^{28}$

In addition, English evidence for the theorbo - which could theoretically act as a substitute for the mean lute in $\mathrm{g}^{\prime}$ due to its tuning - suggests that it was not really used or even widely known during the heyday of the lute song. Although this instrument was apparently first brought to England c.1605 by Inigo Jones (1573-1652), it is mentioned in very few sources pre-1620, and it also appears to have been seen as distinctly Italianate. ${ }^{29}$ Indeed, only one English literary text apparently describes its use to

\footnotetext{
${ }^{20}$ See Thomas Knell, An Epitaph, or rather a short discourse made vpon the life \& death of D. Boner sometimes vnworthy Bisshop of London (London: John Alide, 1569), preface, sig. Av ${ }^{\mathrm{r}}$, where a man sang 'some merie vanitie' about Edmund Bonner, Bishop of London (c.1500-1569) to a 'dull base Lute'; and John Kennedy, The Historie Of Calanthrop And Lvcilla (Edinburgh: John Wreittoun, 1626), sig. E8 ${ }^{\mathrm{r}}$, where a 'trebble' sings to a 'basse Lute'. For English iconographical depictions of lutes, see David van Edwards, 'The Lute Iconography Database', https://lute-images.myjetbrains.com/youtrack/issues/LI? q=country:England.

${ }^{21}$ See Andrew Ashbee, ed., Records of English Court Music (Snodland, Kent: Aldershot, 1986-96), iv (1603-25), 87-8, and 101; and Thomas Campion, The Discription Of A Maske, Presented before the Kinges Maiestie at White-Hall, on Twelfth Night last in honour of the Lord Hayes (London: John Windet, 1607), sig. $\mathrm{A} 4^{\mathrm{r}}$ and $\mathrm{B} 2^{\mathrm{r}}$.

${ }^{22}$ John Dowland, The Third and Last Booke of Songs or Aires (London: Peter Short, 1603), song 21 ('Come when I cal'); John Danyel, Songs for the Lvte Viol and Voice (London: Thomas East, 1606), song 20 ('Now the earth'). A few additional songs have tablature that is a fourth higher than the cantus, which could seem to suggest a bass lute, but this is unlikely; see Table 2.

${ }^{23}$ Praetorius, Syntagma Musicum, ii, 51.

${ }^{24}$ Non-standard tunings for the mean lute are stipulated in only two pieces in the entire printed lute song sources, and both are instrumental pieces; see Danyel, Songs for the Lvte Viol and Voice, no.21 (' $\mathrm{M}^{\mathrm{rs}}$ Anne Grene her leaues bee greene') and John Maynard, The XII. Wonders of the World (London: Thomas Snodham, 1612), no.15 ('Pauin').

${ }^{25}$ As in Dowland's The Third and Last Booke of Songs or Aires, which includes a 'dialogue for a base and meane Lute with fiue voices to sing thereto'.

${ }^{26}$ Lady Mary Wroth, The Countesse of Mountgomeries Urania (London: Augustine Mathewes, 1621), i, 54. See also John Lyly, Sapho and Phao (London: Thomas Cadman, 1584), Act 4, scene iii [sig. Fr] (two references to 'two Lutes tuned in one key'). No contemporary English literary references seem to describe lutes playing together in different tunings.

${ }^{27}$ See Spring, The Lute in Britain, 150-6. The duets for lutes tuned a tone apart appear in 'The Dallis Lute Book' (c.1583), Trinity College Dublin, MS 410; see Linda Sayce, ed., Duets from the Phalèse Anthologies (Oxford: Sul Tasto Publications, distributed by The Lute Society, c.1991), i. Spring (p. 153) also lists a duet in 'Jane Pickeringe's lute book', British Library, MS Egerton $2046(c .1616)$-'the battell for ÿ lutes', fols. $52^{\mathrm{v}}-54^{\mathrm{r}}$ - as being for two lutes tuned a tone apart, but this is for two equally tuned lutes (both 6-course lutes in $\mathrm{g}^{\prime}$ with the sixth course lowered to F); I am grateful to Christopher Goodwin for his help regarding these lute duets.

${ }^{28}$ Richard Robinson, “A perfect-full harmonie": Pitch, Tuning and Instruments in the Elizabethan and Jacobean Mixed Consort', Early Music, 47 (2019), 199-223 (pp. 203-7).

${ }^{29}$ According to the posthumous record of Thomas Plume (1630-1704); see Thomas Plume's Library, Maldon, Essex, Pocket Book no. 25, fol.92 ${ }^{\mathrm{v}}$. The theorbo is first mentioned in English in the Italian-English dictionary of John Florio, $A$ Worlde of Wordes (London: Arnold Hatfield, 1598), 421: 'Tiórba, a kinde of musicall instrument vsed among countrie people'.
} 


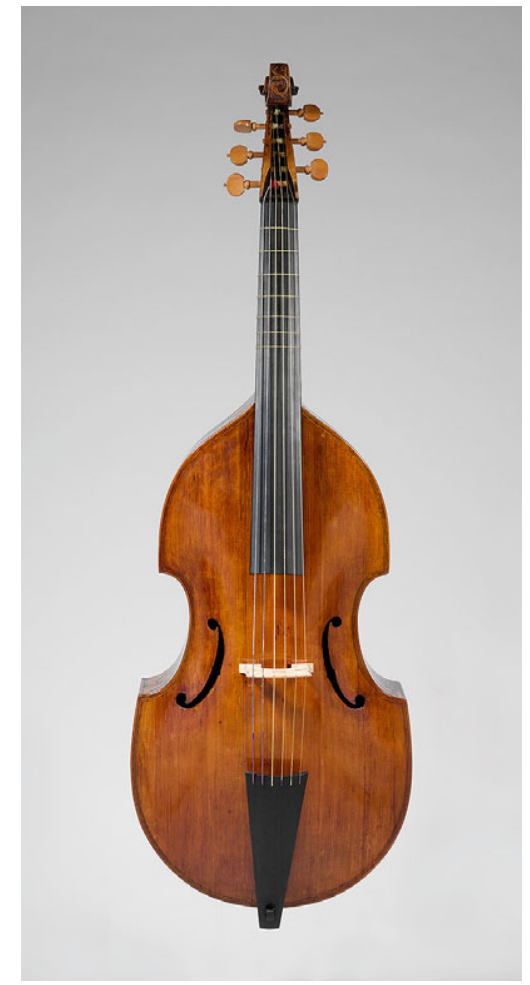

Image 3. John Rose (active 1552-61), Bass viola da gamba c.1600 (accession number 1989.44) (๔ The Metropolitan Museum of Art (MET), New York, with permission).

accompany a solo singer and, significantly, this occurs within a deliberately Italianate context; likewise, the only surviving music printed in England pre-1620 to stipulate a theorbo is a collection of monodies and canzonettas by the Italian composer Angelo Notari (1566-1663). ${ }^{30}$ Theorboes are also very rare in surviving English inventories and other documents until after 1630, ${ }^{31}$ even though one is depicted in the portrait by John de Critz (1551/2-1642) of Mary Sidney, Lady Wroth (1587-1652) from c.1620 held in Penshurst Place.

Lastly, the viol required in these collections appears variously as 'viol de gambo', 'base violl', or simply 'viol(s)' (Image 3). These words are used interchangeably, and there is nothing to suggest that they indicated anything other than an instrument in standardized tuning; indeed, some books explicitly stipulate a bass viol 'tunde the Lute way', that is, its normal tuning of d'-a-e-c-G-D (the tuning of the

\footnotetext{
${ }^{30}$ George Chapman, Al fooles A Comedy (London: George Eld, 1605), Act 2, scene i, at sig. E2 ${ }^{\mathrm{v}}$-sig. E3 ${ }^{\mathrm{r}}$, where Valerio sings to his own accompaniment on theorbo; and Angelo Notari, Prime Mvsiche Nvove (London: Guglielmo Hole, 1613), title page ('... per Cantare con la Tiorba').

${ }^{31}$ See the multivolume collections of 'Records of Early English Drama' (REED, 1979-), http://reed.utoronto.ca; Ashbee, ed., Records of English Court Music; and 'British History Online', www.british-history.ac.uk. Henry Lord Clifford (1592-1643) - the dedicatee of the second book of lute ayres by Thomas Campion (? 1613), and also named on George Mason and John Earsden's song collection (1618) - apparently acquired a theorbo in 1611. Theorboes also appear in the 1615 will of Timothy Bright (c.1551-1615), rector of Barwick-in-Elmet; the 1622 inventory of Sir Charles Somerset (c.1588-1665), son of Edward, Fourth Earl of Worcester (c.1550-1628); and in a 1627 payment to court musician John Kelley 'for a Theorb [...] provided for his Ma ${ }^{\text {ts }}$ service'; see Spring, The Lute in Britain, 371-2; Anon., 'The Will of Timothy Bright, M.D., Rector of Methley and Barwick-inElmet, 1615', Yorkshire Achaeological Journal, 17 (1903), 50-4 (pp. 53-4); Michael G. Brennan, 'Sir Charles Somerset's Music Books (1622)', Music and Letters, 74 (1993), 501-18; and Ashbee, ed., Records of English Court Music, iii (1625-1649), 138.
} 
tenor viol matches that of the mean lute in $\left.\mathrm{g}^{\prime}\right) .{ }^{32}$ The lyra viol is also occasionally called for in the lute song books, yet this is not so much a distinct instrument from the bass viol as an alternative manner of playing, using tablature to accommodate chordal accompaniment and different tunings - a point exemplified by the second book of songs (1601) of Robert Jones (fl. 1597-1615), which includes two options for the bass viol part: the normal bass line ('the base Violl the playne way') and a chordal part written in tablature ('the Base by tableture after the leero fashion'). ${ }^{33}$ Only later on was the lyra viol possibly a distinct instrument in its own right. ${ }^{34}$

Significantly, the written pitch of the bass viol part clearly supports the use of a mean lute in $\mathrm{g}^{\prime}$ (or an orpharion): indeed, only four songs out of the entire printed corpus under consideration have viol and lute parts in different keys, and the wording on two of their respective title pages provides a simple solution to this apparent problem by calling explicitly for lute, orpharion, 'or' bass viol. ${ }^{35}$

\section{Transposition}

Having clarified the lute and viol intended in this repertory, it must briefly be investigated whether contemporary musicians ever transposed lute songs to suit their own pitch preferences. At this time, lute- and viol-sounding pitch was not standardized and partially depended on optimal tensile strength of strings. ${ }^{36}$ However, it seems that pitch may not have varied as widely as is sometimes claimed, and much evidence also survives of lutes playing in ensembles where they had to play to a given pitch. ${ }^{37}$

English lutenists certainly used transposition, for it is discussed in the English version of the famous lute treatise by Adrian Le Roy (c.1520-98), a work which was even cited in the Varietie of Lute-lessons (1610) by Robert Dowland (c.1586-1641). ${ }^{38}$ Yet Le Roy's treatise is of suspect relevance for the lute song. Firstly, he discusses transposition of music for solo lute, not lute with other musicians; secondly, he transposes music written in mensural notation - French chansons by Orlando di Lasso (1530/32-1594) - not music written in tablature; and thirdly, despite writing for those 'without great knowledge of Musicke', his apparently easy method includes errors in the transcriptions. ${ }^{39}$

\footnotetext{
${ }^{32}$ Thomas Ford, Mvsicke of Svndrie Kindes, Set Forth in Two Bookes (London: John Windet, 1607), title page; and Maynard, The XII. Wonders of the World, title page.

${ }^{33}$ I am grateful to John Bryan for clarifying this point. See Robert Jones, The Second Booke of Songs and Ayres (London: Peter Short, 1601), title page. Viol tablature as song accompaniment also occurs in Tobias Hume's The First Part of Ayres (London: John Windet, 1605) and Captaine Hvmes Poeticall Musicke (London: John Windet, 1607). The lyra viol is named in four other lute songs collections - Thomas Ford (1607), William Corkine (1610,1612), and John Maynard (1612) - but is only required for instrumental music like pavans and galliards.

${ }^{34}$ See Christopher Simpson, The Division-Violist: Or an Introduction to the Playing upon a Ground (London: William Godbid, 1659), i, 2, who states that the viol for consort or division use had strings that were 'a little bigger than those of a LyraViol.

${ }^{35}$ These occur in Michael Cavendish, 14. Ayres in Tabletorie to the Lute (London: Peter Short, 1598), song '12' (sic =13) ('Everie bush new springing'); Philip Rosseter, A Booke of Ayres (London: Peter Short, 1601), i, song 9 ('The Sypres curten of the night'); and Thomas Campion, The Third and Fovrth Booke of Ayres (London: Thomas Snodham, c.1618), iii, songs 5 ('So tyr'd are all my thoughts') and 10 ('Breake now my heart and dye'). Cavendish and Campion both stipulate lute, orpharion, 'or' bass viol.

${ }^{36}$ See Robinson, “'A perfect-full harmonie”', 199, no. 5-6. The 'high stretcht lute string' is also mentioned in nonmusical sources like Robert Greene, 'The Tale of Peratio', Greenes Farewell to Folly (London: Thomas Scarlet, 1591), sig. E4 ${ }^{\mathrm{r}}$ and John Donne, Poems, by J.D. VVith Elegies On The Authors Death (London: M. F., 1633), 58 and 339.

${ }^{37}$ See David Tunley, 'Tunings and Transpositions in the Early 17th-Century French Lute Air-Some Implications', Early Music, 21 (1993), 203-9 (pp. 203-4); Robinson, “'A perfect-full harmonie”, 199-203; and Ravens, The Supernatural Voice, 87.

${ }^{38}$ Adrian Le Roy, A briefe and plaine Instruction to set all Musicke of eight diuers tunes in Tableture for the Lute, trans. Francis Kinwelmersh (London: John Kyngston, 1574); Robert Dowland, Varietie Of Lute-lessons (London: Thomas Snodham, 1610), sig. C2 .

${ }^{39}$ Le Roy, A briefe and plaine Instruction, sig. Aiiiv ${ }^{\mathrm{v}}$. Transposing tablature was much less practicable, as noted by Michael Praetorius, Syntagma Musicum, iii, 83. On errors in the transcriptions, see Hector Sequera, 'House Music for Recusants in Elizabethan England: Performance Practice in the Music Collection of Edward Paston (1550-1630)' (Ph.D. diss., University of Birmingham, 2010), 84.
} 
Despite this, the survival of some lute songs in versions using different keys could seem to provide indisputable evidence for transposition, at least in certain cases. A good example is 'Flow my Teares' (or 'Lachrimæ') by John Dowland, which exists in a five-part instrumental arrangement in the same key as the original song (A minor), a setting for mixed consort a fourth higher (D minor), various solo lute versions written both in the original key and a tone lower (A minor and $\mathrm{G}$ minor respectively), and also a setting for bandora ( $\mathrm{C}$ minor). ${ }^{40}$ However, the overwhelming majority of printed lute songs do not survive in such versions; furthermore, rather than indicating possible options for the singer, those few examples of songs that survive in different keys generally suggest that this instead reflected the choice of performing forces (i.e. vocal or purely instrumental). ${ }^{41}$ Transposition of the tablature likewise necessitated rewriting it out, but the small number of surviving examples of songs in different keys raises doubts over the frequency of this practice.

In addition, a tiny handful of printed lute songs have tablature in a different key and pitch to the melody it accompanies (see Table 2). ${ }^{42}$ These songs therefore do not work if performed as written: seven examples occur in Robert Dowland's A Mvsicall Banqvet (1610) alone. Several similar examples also exist in certain manuscript sources such as the 'Dallis Manuscript', Trinity College Dublin, MS 410/1 (c.1583) and British Library, Additional Manuscript 4900 (c.1604). ${ }^{43}$ Yet all these instances can be explained simply through a general desire to avoid ledger lines or too many accidentals in the written vocal part. ${ }^{44}$ The lutenist presumably played the tablature on a mean lute in $\mathrm{g}^{\prime}$ rather than retuning or playing another (differently tuned) lute to match the written vocal pitch in these rare cases; the singer thus inadvertently transposed to fit the lute in these few instances, since this was clearly the simplest (and, by proxy, likeliest) solution. ${ }^{45}$ It therefore seems that lutenists utilized transposition only in specific cases and thus probably did not transpose lute song tablature on a regular basis, if at all.

With the exception of those few songs just discussed, where a musical analysis makes it clear that the singer had to transpose to fit the lute, written evidence that discusses vocal transposition has similarly questionable application to the lute song. Indeed, music instruction manuals such as The pathvvay to Musicke (1596) generally mention this practice in relation to 'plaine song. ${ }^{46}$ This term means a simple melody, like a metrical psalm tune, and it also frequently occurs alongside the word 'descant', in other

\footnotetext{
${ }^{40}$ John Dowland, The Second Booke of Songes or Ayres, of 2.4. and 5. parts (London: George Eastland, 1600), song no. 2. For all 'Lachrimæ' concordances, see Diana Poulton and Basil Lam, eds., The Collected Lute Music of John Dowland (London: Faber Music Limited, 1974), 293-4, no.15.

${ }^{41}$ For an exception, see the manuscript version for voice and lute of 'Can She Excuse My Wrongs' by John Dowland in the socalled 'Turpyn Book of Lute Songs' (c.1610-5), King's College Cambridge, Rowe MS 2, no. 1, transposed up a fourth from the original and with much-changed accompaniment.

${ }^{42}$ To these may be added three of the four songs with bandora accompaniment in Barley, A Nevv Booke of Tabliture, iii (bandora), sig. $\mathrm{C} 2^{v}-\mathrm{D} 2^{r}$, two of which have the cantus a fourth higher than the tablature ('Those eies which set my fancie on a fire'; 'But this \& then no more it is my last of all'), and one of which has the cantus a fifth higher than the tablature ('Howe can the tree but waste and wither away'). See also Edward Filmer, French Covrt-Aires, VVith their Ditties Englished, Offoure and fiue Parts, Together With That Of The Lute (London: William Stansby, 1629), which has only two songs (nos. 1 and 9) that have tablature which matches the written vocal pitch.

${ }^{43}$ See Christopher Goodwin, ed., The English Lute Song before Dowland (Guildford; The Lute Society, 1996 and 1997), i (songs from the Dallis manuscript, $c .1583$ ) and ii (songs from additional manuscript 4900 and other early sources).

${ }^{44}$ See Thomas Morley, A Plaine And Easie Introdvction To Practicall Mvsicke (London: Humphrey Lownes, 1597/1608), iii, 156.

${ }^{45}$ See Goodwin, The English Lute Song before Dowland, i, 7 and ii, 8-9; and Tunley, 'Tunings and Transpositions', 203-9.

${ }^{46}$ See anon., The pathvvay to Musicke (London: J. Danter, 1596), title page and sig. $\mathrm{F}^{\mathrm{v}}-\mathrm{G}^{\mathrm{v}}$; William Bathe, A Briefe Introduction to the Skill of Song (London: Thomas East, ?1596), sig. $\mathrm{B}^{\mathrm{v}}-\mathrm{Biv}^{\mathrm{r}}$; Andreas Ornithoparchus, Andreas Ornithoparcvs His Micrologvs, Or Introdvction: Containing the Art of Singing, trans. John Dowland, (London: Thomas Snodham, 1609), i, 26-8; and John Hopkins and Thomas Sternhold, The Whole Booke of Psalmes, collected into Englysh metre (London: John Day, 1562), 'A shorte Introduction into the Science of Musicke, made for such as are desirous to haue the knowledge therof, for the singing of these Psalmes', sig. $+\mathrm{ii}^{\mathrm{r}}-[+\mathrm{vii}]^{\mathrm{r}}$. Other music instruction books - including those by Thomas Morley (1597), Thomas Robinson (1603), Thomas Campion (1610), Thomas Ravenscroft (1614), and Elway Bevin (1631) - are equally silent regarding transposition of music like lute songs.
} 
Table 2. Lute Songs in the Printed Collections (1597-1622) with Pitch Disparity between Voice and Lute Tablature

\begin{tabular}{|c|c|c|}
\hline Composer \& Collection & Song & Comments \\
\hline $\begin{array}{l}\text { Thomas Morley, Canzonets or Litle } \\
\text { Short Aers to Five and Sixe Voices } \\
(1597)\end{array}$ & $\begin{array}{l}\text { 1. Fly loue that art so sprightly } \\
\text { 4. Loues folke in greene araying } \\
\text { 8. Sou'raign of my delight }\end{array}$ & $\begin{array}{l}\text { 1: Cantus is a tone higher than the lute } \\
\text { tablature } \\
4 \text { \& } 8 \text { : Cantus is a fourth higher than the } \\
\text { lute tablature }\end{array}$ \\
\hline $\begin{array}{l}\text { Michael Cavendish, 14. Ayres in } \\
\text { Tabletorie to the Lute (1598) }\end{array}$ & $\begin{array}{l}\text { '12'. [sic=13.] Everie bush new } \\
\text { springing }\end{array}$ & $\begin{array}{l}\text { Cantus and bassus agree; lute tablature } \\
\text { is a fifth lower than the cantus and } \\
\text { bears the instruction 'this fift rule is } \\
\text { Gam ut' }\end{array}$ \\
\hline Philip Rosseter, A Booke of Ayres (1601) & I, 9. The Sypres curten of the night & $\begin{array}{l}\text { Voice and bass (viol) agree; lute } \\
\text { tablature is a tone lower than cantus }\end{array}$ \\
\hline $\begin{array}{l}\text { Robert Dowland, A Mvsicall Banqvet } \\
\text { (1610) }\end{array}$ & $\begin{array}{l}\text { 3. O eyes leaue off your weeping } \\
\text { 6. To plead my faith } \\
\text { 11. Si le parler et le silence } \\
\text { 12. Ce penser qui sans fin } \\
\text { 13. Vous que le bon heur r'appelle } \\
\text { 14. Passaua amor } \\
\text { 15. Sta note mien yaua }\end{array}$ & $\begin{array}{l}\text { 3, } 6,11-14: \text { Cantus/canto is a tone } \\
\text { higher than the lute tablature; lute } \\
\text { and bassus/basso agree } \\
\text { 15: Canto is a tone lower than the lute } \\
\text { tablature; lute and basso agree }\end{array}$ \\
\hline $\begin{array}{l}\text { Thomas Campion, The Third and Fovrth } \\
\text { Booke of Ayres (c. 1618) }\end{array}$ & $\begin{array}{l}\text { iii, 5. So tyr'd are all my thoughts } \\
\text { iii, } 7 \text {. Kinde are her answeres } \\
\text { iii, 10. Breake now my heart and } \\
\text { dye }\end{array}$ & $\begin{array}{l}\text { iii, 5: Cantus and bassus agree; lute } \\
\text { tablature is a minor third higher } \\
\text { iii, } 7 \text { : Cantus is a tone higher than the } \\
\text { lute; bassus and tablature agree } \\
\text { iii, 10: Cantus and bassus agree; lute } \\
\text { tablature is a fourth higher }\end{array}$ \\
\hline $\begin{array}{l}\text { George Mason \& John Earsden, The } \\
\text { Ayres that vvere svng and played, at } \\
\text { Brougham Castle in Westmerland, in } \\
\text { the Kings Entertainment (1618) }\end{array}$ & $\begin{array}{l}\text { 7. The shadowes darkning our } \\
\text { intents } \\
\text { 9. O Stay! sweet is the least delay }\end{array}$ & $\begin{array}{l}7 \& \text { 9: Lute tablature is a fourth higher } \\
\text { than the voice }\end{array}$ \\
\hline
\end{tabular}

Note. The data assume the use of a mean lute in g' for the lute tablature in all pieces. Theoretically, the use of a bass lute in d' resolves the pitch disparity in Campion's The Third and Fovrth Booke of Ayres, iii, song 10; and Mason \& Earsden, The Ayres that vvere svng and played, songs 7 and 9. However, this solution seems unlikely since it would in turn imply that the remaining pieces in the table also require differently tuned lutes, which is problematic in terms of (a) the miniscule total number of pieces that fit those apparent tunings, (b) the lack of stipulation for such lutes in the respective songbooks, and (c) the lack of evidence for lutes in such tunings in other English sources.

words indicating a tenor or ground upon which polyphonic music is based. ${ }^{47}$ Discussions of vocal transposition therefore do not relate to songs accompanied by instruments, particularly those reading from tablature.

There is also nothing in the voice parts of the lute songs that particularly suggests transposition possibilities. For example, an F3-clef or even a C4 or C3-clef in the bass part of around 40 of the printed lute songs could initially imply chiavette clef combinations (indicating downwards transposition, typically by a fourth). ${ }^{48}$ However, this reading is at best unlikely and in reality unconvincing, since comparison of all the songs in the books where a chiavette song seems to occur actually reveals that the

\footnotetext{
${ }^{47}$ Richard Allison, The Psalmes Of Dauid in Meter (London: William Barley, 1599), title page, defines 'plaine song' as 'the common tunne to be sung' (i.e. the metrical psalm tune), whilst Morley uses it simply to mean a basic melody; see Christopher R. Wilson and Michela Calore, Music in Shakespeare: A Dictionary (London: Thoemmes, 2005), 337-8. On 'plaine song' and 'descant', see for example George Gascoigne, A Hundreth sundrie Flowres bounde vp in one small Poesie (London: Henry Bynneman and Henry Middleton, 1573), 272.

${ }^{48}$ For more on chiavette, see Kenneth Kreitner, 'Renaissance Pitch', Companion to Medieval and Renaissance Music, ed. Tess Knighton and David Fallows (Oxford: Oxford University Press, 1997), 275-83 (pp. 279-81). Only two printed lute songs have bass parts in C-clefs: Cavendish, 14. Ayres in Tabletorie to the Lute, song '15' (sic =song 16: 'Say shepherds say', C4-clef) and Danyel, Songs for the Lvte Viol and Voice, song 19 ('What delight can they inioy', C3-clef). Lute songs with an F3-clef in the bass part occur in the books by Cavendish (1598), John Dowland (1597, 1603, 1612), Robert Jones (1605, 1609, 1610), John Coprario (1606), John Danyel (1606), Robert Dowland (1610), and Thomas Campion (? 1613 [i], c.1618 [iii]).
} 
written cantus ranges do not differ substantially from one another, if at all. A notable exception is John Dowland's A Pilgrimes Solace (1612), which contains eight songs with bass parts in F3-clefs and high cantus parts, but the chiavette solution is problematic here for several reasons. ${ }^{49}$ Firstly, a bass lute would be required for these potential chiavette songs, but nothing in the book suggests this (it calls simply for 'the Lute') - surely an oversight given the apparent rarity of such instruments. Secondly, Dowland's other lute song books (including those with F3-clefs) do not convincingly employ chiavette, so their use in $A$ Pilgrimes Solace would be difficult to explain; the same is true of the other lute song books produced by the printers linked to A Pilgrimes Solace.$^{50}$ In fact, the eight songs in question are no higher if performed as written (reaching up to $\mathrm{g}^{\prime \prime}$ or $\mathrm{a}^{\prime \prime}$ ) than a large number of other songs in the printed lute song collections. In any case, the practice seems to have been used in England primarily in sacred, not secular, music. ${ }^{51}$

It therefore seems that, rather than transposing, one was instead expected to learne quickly in what cléefe you should take your part'. ${ }^{52}$ Indeed, two of the printed lute song books state that they were written for 'all the partes together, or either of them seuerally', clearly suggesting possible solo use of any voice part (irrespective of whether this was primarily a marketing ploy or not). ${ }^{53}$ The lute song repertory thus seems to have been printed in a format which was intended to facilitate instant performance. This links more generally to a culture of music-making in which one could 'in short time [...] sing a difficult song of himselfe, without any Instructor', ${ }^{44}$ an attitude exemplified by Edward Herbert, Lord Baron of Cherbury (1582/3-1648), who claimed that during his undergraduate days in the 1590s, he had 'attaind also to sing my part at first sight in Musicke, and to play on the Lute with very litle or almost noe teaching. ${ }^{55}$ The lute song books themselves likewise occasionally speak directly to an amateur reader. ${ }^{56}$ Thus, in short, there seems little reason to doubt that the obvious solution was the one intended by the composers and printers of the lute songs.

\section{Voices and the Lute Song: Evidence from the Music}

The combination of all the evidence presented above regarding different instruments, transpositions, and pitch possibilities raises important questions in relation to the sung melody, since it seems most likely that these aspects were considered to be reasonably fixed. What, therefore, does this tell us about the voice(s) that sang this repertory?

\footnotetext{
${ }^{49}$ John Dowland, A Pilgrimes Solace (London: Thomas Snodham, 1612), songs 3, 4 (also with F4-clef), 6, 13, 17, 18, 20 , and 21 (chorus only; the verse is in an F4-clef).

${ }^{50}$ The printers linked to A Pilgrimes Solace are Mathew Lownes, Thomas Snodham, John Browne, and William Barley. Between them, they were responsible for printing most of the surviving lute song collections from 1609-22.

${ }^{51}$ See Andrew Johnstone, “'High clefs' in composition and performance', Early Music, 34 (2006), 29-53. For an example of Continental usage, see Praetorius, Syntagma Musicum, iii, 80-5.

${ }^{52}$ Luigi Pasqualigo, [Fedele and Fortunio], trans. Anthony Munday (London: John Charlewood, 1585), Act 3, scene ii, sig. Ei ${ }^{\mathrm{v}}$. See also Everard Digby, Everard Digbie his Dissuasiue. From taking away the lyuings and goods of the Church (London: Robert Robinson and Thomas Newman, [1590]), preface, sig. $2^{\mathrm{v}}$ ( =sig. A6 $)$ : ' $\ldots$ in the eares of some, I may seeme to sing the treble rather than the meane, to misse the moode, and to mistake the figure, and therewith to sound some sharps insteed of flattes'.

${ }^{53}$ John Dowland, The First Booke of Songes or Ayres (London: Peter Short, 1597), title page; and Robert Jones, The First Booke of Songes or Ayres (London: Peter Short, 1600), title page. Both books were printed by Peter Short, who seems to have recycled the same cover design. The same solution also occurs in Allison, The Psalmes Of Dauid in Meter, whose title page notes that 'the singing part' is 'to be either Tenor or Treble to the Instrument, according to the nature of the voyce, or for foure voyces'. For examples in related repertory, see John Griffiths, 'The Vihuela: Performance Practice, Style, and Context', Performance on Lute, Guitar and Vihuela: Historical Practice and Modern Interpretation, ed. Victor Anand Coelho (Cambridge: Cambridge University Press, 1997/2005), 158-79 (p. 166).

${ }^{54}$ Bathe, A Briefe Introduction to the skill of Song, sig.Aiii ${ }^{\mathrm{r}}-$ sig.Aiii ${ }^{\mathrm{v}}$. See also Le Roy, A briefe and plaine Instruction, sig.Aiii ${ }^{\mathrm{v}}$ and Morley, A Plaine And Easie Introdvction, ii, 115.

${ }^{55}$ J. M. Shuttleworth, ed., The Life of Edward, First Lord Herbert of Cherbury, written by himself (London: Oxford University Press, 1976), 16-17.

${ }^{56}$ For example, see Jones, The Second Booke of Songs, sig. A2 ${ }^{\mathrm{v}}$ ('To the Reader'), which includes a brief explanation of 'prickesong Notes' for the 'better instruction' of the performer.
} 


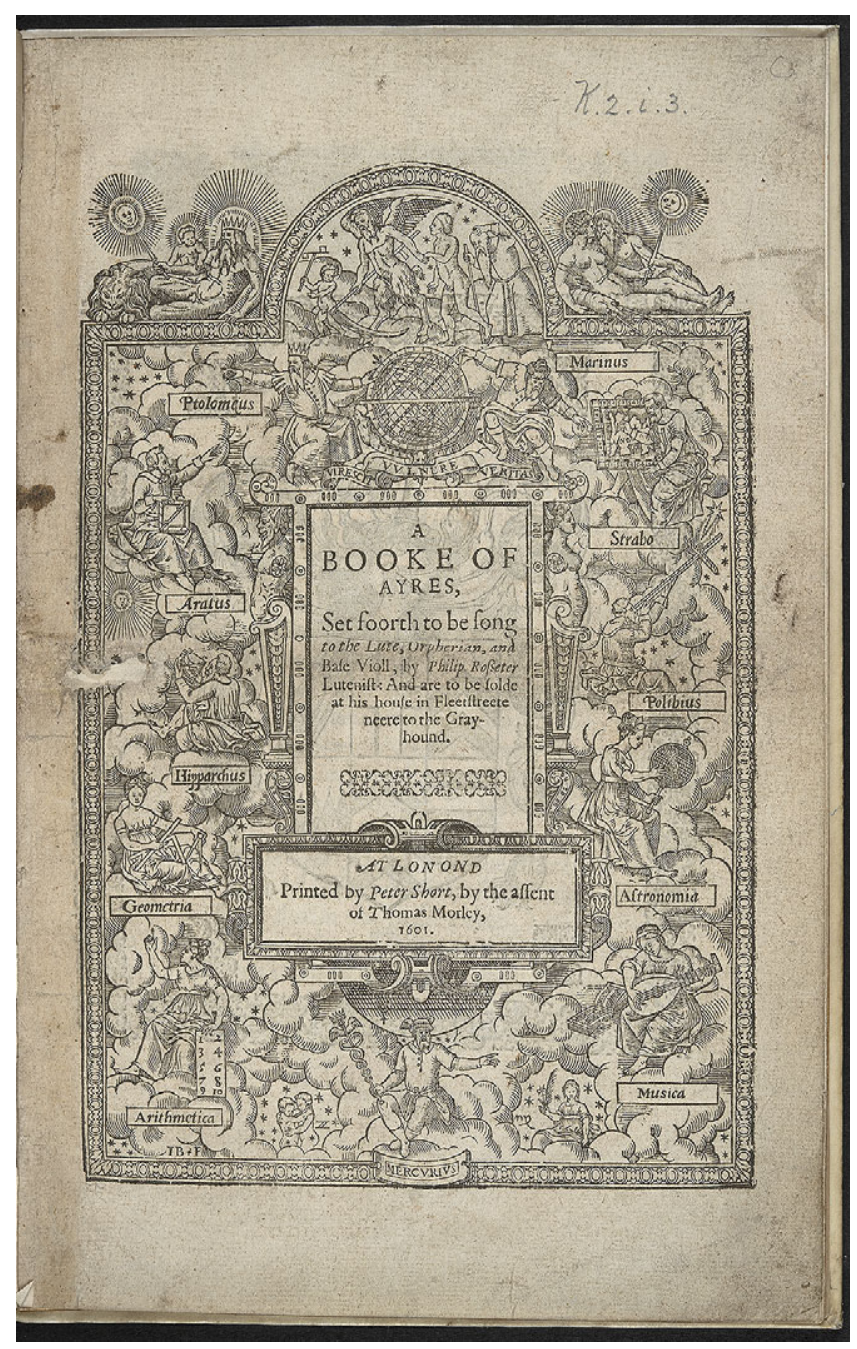

Image 4a. Philip Rosseter (1568-1623) and Thomas Campion (1567-1620), A Booke of Ayres, Set foorth to be song to the Lute, Orpherian and Base Violl (London; Peter Short, 1601), title page (British Library, Music Collections K.2.i.3.) (๔ British Library Board, with permission).

The title pages, prefaces and dedications in the lute song collections give almost no clues regarding the intended voice(s); they simply state that it is music 'to sing' (or 'to be svng') or instead stipulate a 'voyce' (or, where applicable, 'voyces') (Image $4 \mathrm{a}$ and $4 \mathrm{~b}$ ). The only three exceptions to this - Vltimvm Vale (1605) by Robert Jones (c.1577-1617), the Fvneral Teares (1606) by John Coprario (c.1570-1626), and $A$ Booke of Ayres (1606) by John Bartlet (fl. 1606-10) - all indicate a 'treble voice' or 'two Trebles'. ${ }^{57}$ An additional hint is provided by Coprario, who also mentions a 'mean part' which 'may be added, if any shall affect more fullness of parts', yet interestingly, this 'mean part' is called 'alto' in the music itself. ${ }^{58}$

\footnotetext{
${ }^{57}$ Robert Jones, Vltimvm Vale, with a triplicity of Musicke (London: John Windet, 1605), title page; John Coprario, Fvneral Teares. For the death of the Right Honorable the Earle of Deuonshire (London: John Windet, 1606), title page; John Bartlet, $A$ Booke of Ayres VVith a Triplicitie of Musicke (London: John Windet, 1606), title page.

${ }^{58}$ This 'alto' part has an overall range g- $\mathrm{d}^{\prime \prime}$. Interestingly, Florio, A Worlde of Wordes, 15 translates 'alto' in its musical sense as 'a treble in song and musicke.'
} 


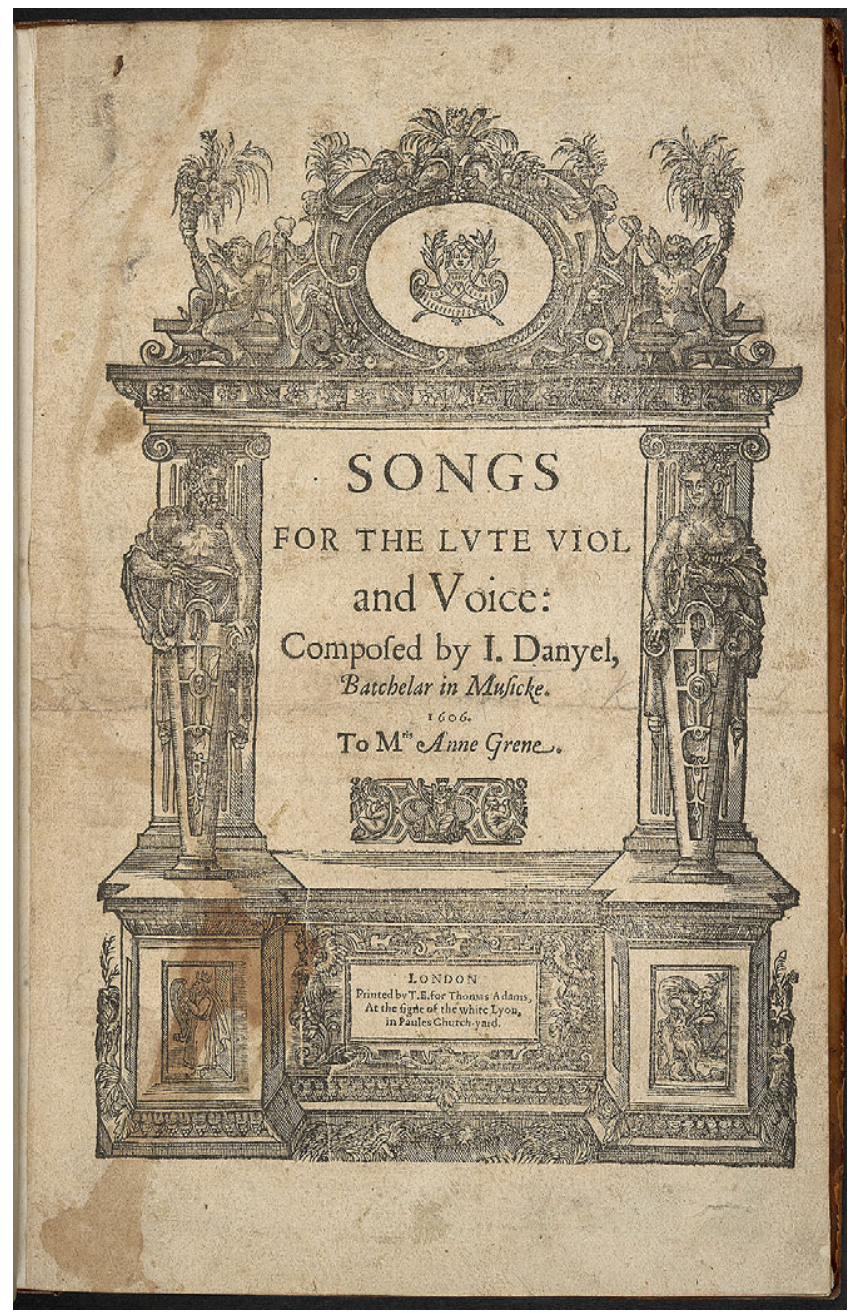

Image 4b. John Danyel (1564-c.1626), Songs for the Lvte, Viol and Voice (London; Thomas East, 1606), title page (British Library, Music Collections K.2.g.9.) (৫ British Library Board, with permission).

These 'treble' and 'mean' stipulations probably refer primarily to boys' voices, ${ }^{59}$ even though the word 'treble' was also sometimes used to describe a female voice. ${ }^{60}$

Just like 'treble' and 'mean', the words 'cantus' and 'altus' are also linked more generally to children. ${ }^{61}$ Judged on evidence from contemporary literary sources, it seems that the boys who sang such treble and

\footnotetext{
${ }^{59} \mathrm{~A}$ famous example of 'treble' and 'mean' to describe boys' voices occurs in Calendar of the Cecil Papers in Hatfield House: Volume 6, 1596, ed. Richard A. Roberts (London: Her Majesty's Stationery Office, 1895), 68 (Lord Burgh to Robert Cecil, on the voices of three boys, one as 'an excellent treble' and another as 'a very high mean'). See also John Marston, The History of Antonio and Mellida. The first part. (London: Richard Bradock, 1602), Act 5, at sig. H4 ${ }^{\mathrm{r}}$; John Marston, VVhat Yov VVill (London: George Eld, 1607), Act 2, scene i, at sig. $\mathrm{D}^{\mathrm{r}}$; and George Dobson (att.), Dobsons Drie Bobbes: Sonne and Heire to Skoggin (London: Valentine Simmes, 1607), sig. F3 .

${ }^{60}$ As in Torquato Tasso, Godfrey of Bulloigne, or The Recouerie of Ierusalem, trans. Edward Fairfax (London: Arnold Hatfield, 1600), xv, 279 v.62 ('she warbled forth a treble small') and Gonzalo de Céspedes y Meneses, Gerardo The Vnfortunate Spaniard, trans. Leonard Digges (London: George Purslowe, 1622), i (discourse 2), 72 ('he ghessed it vvas a vvoman [...] by the sweetnesse of her trebble').

${ }^{61}$ Thomas Whythorne, Cantus. Of duos, or songs for tvvo voices (London: Thomas East, 1590), title page; and Dowland, Andreas Ornithoparcvs His Micrologvs, iv, 83. For representative examples of 'treble' and 'mean' referring generally to children,
} 
mean parts could have been aged up to 14 or 15 years old and were expected to have ranges from around $\mathrm{a}, \mathrm{b}$, or $\mathrm{c}^{\prime}$ up to $\mathrm{g}^{\prime \prime}$ or $\mathrm{a}^{\prime \prime}$, which perfectly suits the treble and mean range 'cantus' parts in the lute song collections. ${ }^{62}$ Although still relatively uncommon today, ${ }^{63}$ performances of lute songs by boy trebles were clearly more widespread $c .1600$, as substantiated by references in literary sources, noble correspondence, state documents, and also stage productions, particularly those of the children's drama companies. ${ }^{64}$ Alongside descriptions of a character like a pageboy singing to a lute or viol, as in two plays by Nicholas Breton (?1545-?1626), ${ }^{65}$ boys also played female characters, as documented explicitly in VVhat Yov VVill by John Marston (1576-1634), where the schoolboy Holifernes Pippo was granted leave 'to play the Lady in commedies presented by Children'. ${ }^{66}$ Unsurprisingly, some of those plays performed 'by Her Maiesties Children, and the boyes of Paules', like John Lyly's (?1554-1606) Sapho and Phao (1584) and Marston's The Dutch Courtezan (1605), also included a female character who 'singes to her Lute'. ${ }^{67}$

Turning to the inside of the songbooks and the music itself, the part designations do not really elucidate further the question of the intended voice(s) (Image 5). What at first glance appears to be a correlation between the names 'cantus', 'altus', 'tenor', and 'bassus' and their modern choral counterparts turns out to be rather less clear-cut; indeed, it quickly becomes apparent that these names primarily indicate the hierarchical relationship of one part to another rather than the assignment of each part to an exact vocal type and range. ${ }^{68}$ For example, a number of the songbooks include songs with 'cantus' and 'altus' ranges and clefs that are virtually or even completely identical to one another, such as 'Sweet was the song' by John Attey (d.c.1640), where both the 'cantus' and 'altus' parts use a G2-clef and have a range of $\mathrm{e}^{\prime}$ to $\mathrm{a}^{\prime \prime}$, or 'On a time in summers season' by Robert Jones, where both parts use C1-clefs and have a range of $\mathrm{d}^{\prime}$ to $\mathrm{e}^{\prime \prime} .{ }^{69}$ In contrast, other songbooks have 'altus' parts that are decidedly 'tenor-like' in register

see Helkiah Crooke, Mikrokosmographia: A Description of the Body of Man (London: William Jaggard, 1615), viii, 633; and John Dee (attrib.), Aristotles Politiqves, Or Discovrses Of Government (London: Adam Islip, 1598), viii, 393.

${ }^{62}$ Scipion Dupleix, The Resoluer; Or Curiosities of Nature (London: N. \& I. Okes, 1635), 7-8. Several contemporary sources cite Aristotle on this point, like Anon., The Problemes Of Aristotle, with other Philosophers and Phisitions (Edinburgh: Robert Waldgrave, 1595), sig. M8 ${ }^{v}$. See also Morley, A Plaine and Easie Introdvction, iii, 166, and Praetorius, Syntagma Musicum, ii, sig. $\mathrm{Cii}^{\mathrm{v}}$ ( =p.20), Tabella iv (Vox viva seu humana). See also Ashbee, ed., Records of English Court Music, viii (1485-1714), 55-6 (entry for 1604, describing how the 'said children, having served three years or more in his Highness' [ =James I] Chapel, shall by change of their voice become unmeet for that service').

${ }^{63}$ Most modern commercial recordings of lute songs do not use a boy treble; notable exceptions are A Quiet Conscience: Songs from the $17^{\text {th }}$ Century, Connor Burrowes (treble), John Scott (organ), David Miller (lute/theorbo), Guild GMCD 7150 (released 1998); and Shakespeare's Musicke: Sung in Authentic Elizabethan Pronunciation, Simon Giles (treble), David Dyer (tenor), Camerata of London, dir. Barry Mason, Meridian CDE 84198 (released 1990).

${ }^{64}$ See Linda Phyllis Austern, Music in English Children's Drama of the Later Renaissance (Philadelphia: Gordon and Breach, 1992), 12-13, 24, 52-3 and 254-66; and David Grote, The Best Actors in the World: Shakespeare and his Acting Company (London: Greenwood Press, 2002), 11-13.

${ }^{65}$ Nicholas Breton, The Strange Fortvnes Of Two Excellent Princes (London: Peter Short, 1600), 38 (a pageboy sings to his lute)

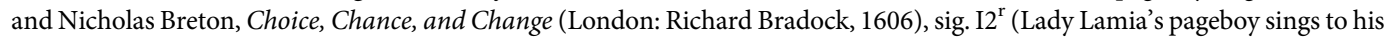
'base violl').

${ }^{66}$ Marston, VVhat Yov VVill, Act 2, scene i (sig. $\mathrm{D}^{\mathrm{r}}$ )

${ }^{67}$ Lyly, Sapho and Phao, Act 3, scene iii (sig. $\mathrm{E}^{\mathrm{r}}-\mathrm{E}^{\mathrm{v}}$ ); and John Marston, The Dutch Courtezan (London: Thomas Purfoot, 1605), Act 1, scene ii (sig. B2 ${ }^{\mathrm{v}}$ ). Incidentally, Thomas Ravenscroft, 'Preface', A Briefe Discovrse Of the true (but neglected) vse of Charact'ring the Degrees [...] in Measurable Musicke (London: Edward Allde, 1614), sig. $\mathrm{A} 2^{\mathrm{r}}-\mathrm{A} 2^{\mathrm{v}}$, praises a certain Edward Pearce, 'sometimes Maister of the Children of Saint Paules in London' both for 'Educating of Children for the ordering of the Voyce [...] And also in those his Compositions to the Lute, whereof, the world enioyes many'.

${ }^{68}$ The idea of part names functioning primarily as signposts for the rank order of individual musical lines in a composition can be traced back to the thirteenth-century 'Tenor' (from the Latin 'teneo, tenere', to hold) and via later polyphonic developments, where the 'Tenor' often carried a pre-existent tune or cantus firmus; for example, see Christopher Page, The Summa Musice: A Thirteenth-Century Manual for Singers (Cambridge: Cambridge University Press, 1991), 108-9; and David J. Rothenberg, The Flower of Paradise: Marian Devotion and Secular Song in Medieval and Renaissance Music (Oxford: Oxford University Press, 2011), 159-60.

${ }^{69}$ John Attey, The First Booke of Ayres of Fovre Parts (London: Thomas Snodham, 1622), song 12; and Robert Jones, A Mvsicall Dreame, or the Fovrth Booke of Ayres (London: John Windet, 1609), song 7. Further examples of exact or near-identical cantus and altus ranges occur in the other lute song collections. 


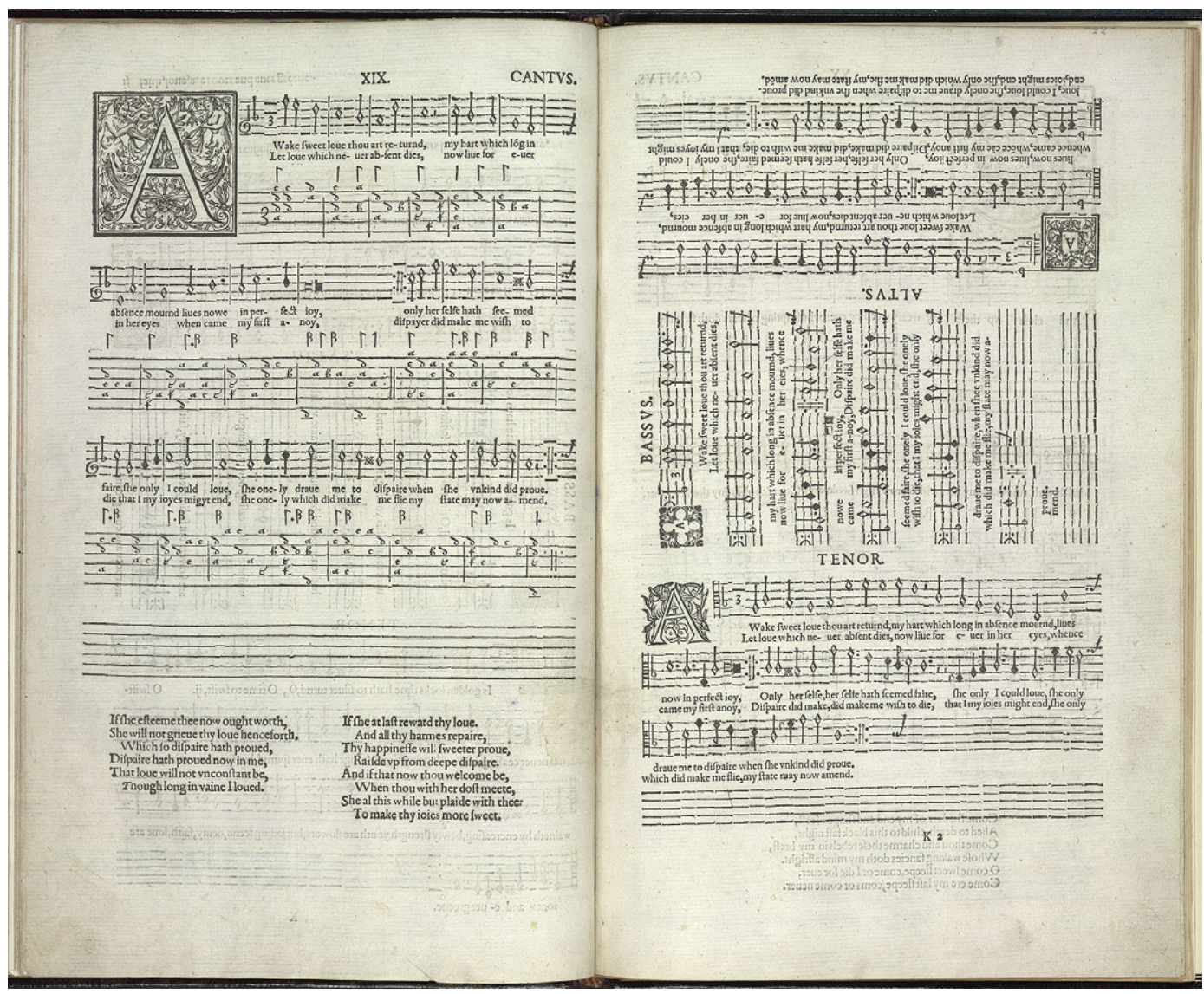

Image 5. John Dowland (1563-1626), The First Booke of Songes or Ayres of foure partes with Tableture for the Lute (London; Peter Short, 1597), song 19 (sig. $\mathrm{K}^{\mathrm{V}}-\mathrm{K} 2^{\mathrm{r}}$ ): 'Awake sweet loue' (British Library, Music Collections K.2.i.4.) (৫ British Library Board / Bridgeman Images, with permission).

and also exhibit terminological fluidity between part names, as exemplified via comparison of three songs by Thomas Campion (1567-1620): 'Vaine men whose follies make a God of Loue' ('altus', C3-clef, range $\mathrm{d}$ to $\mathrm{f}^{\prime}$ ), 'Harden now thy tyred hart' ('contratenor', yet with identical clef and range as the former example), and 'Now hath Flora' (whose 'Tenor part' is written in both C2 and C3-clefs with range d to g'). ${ }^{70}$ Similar instances between 'tenor' and 'bassus' parts could likewise be highlighted; for a pertinent example, compare the 'Basso' of 'What delight can they inioy' (C3-clef, range d to g') by John Danyel (1564-c.1626) with the 'Tenore' of another one of his songs, 'Now the earth' (C4-clef, range $\mathrm{c}$ to $\left.\mathrm{e}^{\prime}\right) .{ }^{71}$ More significantly, in some of the collections for solo voice, like the two books of ayres (1610 and 1612) by William Corkine

\footnotetext{
${ }^{70}$ Thomas Campion, Tvvo Bookes of Ayres (London: Thomas Snodham, ?1613), ii, songs 1 and 3; and Campion, The Discription of a Maske [...] in honour of the Lord Hayes, sig. E3 ': 'A Tenor part to the first Song' (i.e. 'Now hath Flora'). For another example of a low alto part (C3-clef, range $\mathrm{f} \#$ to b), see the dialogue 'Hvmor say what mak'st thou' in Dowland, The Second Booke of Songes or Ayres, song 22.

${ }^{71}$ Danyel, Songs for the Lvte Viol and Voice, songs 19 and 20. The argument that song 19 might exploit possible chiavette is unconvincing: firstly, this would require a bass lute, yet no such lute is indicated - an odd oversight given that a bass lute is explicitly stipulated in song 20 under the 'Canto Secundo'. Secondly, the written range of the 'Canto Primo' in song $19\left(\mathrm{~d}^{\prime}-\mathrm{f}^{\prime \prime}\right)$ closely matches the other cantus ranges in Danyel's collection. Only songs 4, 18, and 19 have bass-part clefs that could suggest downwards transposition, yet nothing explains why these songs require a lower tessitura than the remaining 18; their clefs also do not match typical chiavette found elsewhere.
} 
(fl. 1610-17), the word 'cantus' is routinely applied to the texted melody irrespective of its actual written pitch and clef (which sometimes extends down to $c$ and uses a C3-clef). ${ }^{72}$ Thus, whilst it would be wrong to claim that the part designations in these lute song collections are completely arbitrary or that they are so broad in application as to be totally meaningless, it is also clear that they are not intended to indicate a precise vocal type or range. Indeed, it is perhaps worth highlighting here that the words 'cantus' and 'altus' generally seem not to have described a voice type ('treble' and 'mean' were typically used instead). ${ }^{73}$

In addition, a musical analysis of the sung melody in the printed lute song collections reveals an overwhelming predominance of high clefs and range. ${ }^{74}$ This can be explained simply in the songs scored for multiple voices via the 'familiar and infallible' harmonic rules which governed the process of writing 'parts in counter-point', for the presence of lower voices clearly necessitates a high (i.e. 'treble') melody. ${ }^{75}$ Yet significantly, of the 322 songs scored for solo voice, only 21 have melodies that exploit lower written ranges and clefs (C3, C4, and F4-clefs, i.e. alto, tenor, and bass-clefs) (see Table 3); in contrast, 232 are in a G2-clef (=treble-clef), 68 are in a C1-clef (=soprano-clef) and one is in a C2-clef ( =mezzo-soprano-clef) - that is, a total of 301 'high' solo songs or $93 \%$ of the overall total of solo songs (see Figure 1). These solo song melodies generally have a range of around an octave to a minor tenth (see Figure 2), normally somewhere within the compass of $\mathrm{d}^{\prime}-\mathrm{g}^{\prime \prime}$ (i.e. the lowest and highest notes within a treble stave without using ledger lines); this incidentally matches the typical upper part of the songs set for multiple voices. Indeed, over $75 \%$ of the solo songs reach $\mathrm{e}^{\prime \prime}$ or above. The total number of songs scored for a low solo voice can be extended only marginally beyond 21 songs by including the solo parts in the occasional dialogues and ensemble songs from masques that appear in these collections. ${ }^{76}$

It is well known that, alongside evidence for boys singing songs to lute or bass viol accompaniment, many references survive in plays, literary sources and letters which describe a woman singing to a lute or (less frequently) bass viol. ${ }^{77}$ Such references can be contextualized within the frequently voiced contemporary opinion that musical skills ranked amongst those accomplishments which were 'fit for a Lady or Gentlewoman to doe', and with which she could 'gette the lykinge of any man'. ${ }^{78}$

Yet evidence for performance of songs or 'ditties' by a man with a lute in contemporary written sources appears with similar frequency as texts documenting performance by women. ${ }^{79}$ Indeed, numerous literary references describe a lovesick suitor trying to woo his beloved or ease his suffering from the 'straunge effects of loue' by singing with his lute, ${ }^{80}$ whilst other evidence includes references to named male lutenist-singers who were employed at court, such as Guillaume de Vermigny in the early

\footnotetext{
${ }^{72}$ William Corkine, Ayres, to Sing and Play to the Lvte and Basse Violl (London: William Stansby, 1610); and William Corkine, The Second Booke of Ayres (London: Mathew Lownes, John Browne and Thomas Snodham, 1612).

${ }^{73}$ See Dowland, Andreas Ornithoparcvs His Micrologvs, iv, 83 ('Of the Discantus').

${ }^{74}$ The same is also true of lute song manuscript sources; for three notable exceptions, see the 'Turpyn Book of Lute Songs' (c.1610-15), King's College Cambridge, Rowe MS 2, no. 11 ('Most men do loue the Spanish wyne'), where the sung melody is in an F4-clef; 'Ann Twice, Her Book' (c.1620-30), New York Public Library, Drexel MS 4175, no. 21 ('Why should passion leade mee blinde'), where the sung melody is in a C3-clef; and 'The Dallis Lute Book', pp. 204-7 ('In youthfull yares'), whose sung melody is in a C2-clef and C3-clef.

${ }^{75}$ Thomas Campion, A Nevv VVay of making Fowre Parts in Counter-point [...] with a briefe method teaching to sing (London: John Browne, 1610), title page.

${ }^{76}$ Alfonso Ferrabosco II, Ayres: by Alfonso Ferrabosco (London: Thomas Snodham, 1609), dialogues 26, 27, 28; Ford, Mvsicke of Svndrie Kindes, book 1, dialogue 11; George Mason and John Earsden, The Ayres that vvere Svng and Played, at Brougham Castle in Westmerland, in the Kings Entertainment (London: Thomas Snodham, 1618), dialogues 1 and 2, masque songs 6 and 8 (for large ensemble).

${ }^{77}$ For representative examples, see Robert Greene, Philomela The Lady Fitzvvaters Nightingale (London: R. Bourne and Edward Allde, 1592), sig. B3 ${ }^{\mathrm{v}}$ (Philomela sings several 'odes' to her lute) and Luis Hurtado (attrib.), The Third and last part of Palmerin of England, trans. Anthony Munday (London: James Roberts, 1602), iii, p. $119^{\mathrm{v}}$ (Laurea sings to her 'Violl de gamba').

${ }^{78}$ These quotations are taken respectively fromThomas Nash, Qvaternio Or A Fovrefold VVay To A Happie Life (London: John Dawson, 1633), 156; and Austin Saker, Narbonus. The Laberynth Of Libertie (London: Richard Johnes, 1580), i, 123-4.

${ }^{79}$ Literary sources frequently describe the performance of 'ditties' (presumably songs like ayres) with a lute; see John Bodenham, Englands Helicon (London: James Roberts, 1600), sig. X2 ${ }^{\mathrm{r}}$, who includes three songtexts from Dowland, The First Booke of Songes and refers to them explicitly as 'ditties'.

${ }^{80}$ George Whetstone, The Rocke of Regard, diuided into foure parts (London: Henry Middleton, 1576), i, 32-3.
} 
Table 3. Songs for Solo Voice Using Low Clef(s) and Range

\begin{tabular}{|c|c|c|c|}
\hline Composer / Collection & Song & Clef(s) & Range \\
\hline \multirow[t]{2}{*}{ Tobias Hume, The First Part of Ayres (1605) } & $\begin{array}{l}\text { 1. The Souldiers Song. I sing the } \\
\text { praise of honor'd wars }\end{array}$ & $\mathrm{G} 2, \mathrm{C} 1, \mathrm{C} 2$ \& $\mathrm{C} 3$ & $g-g ”$ \\
\hline & 114. Alas poore men & $\mathrm{G} 2, \mathrm{C} 1, \mathrm{C} 3, \mathrm{C} 4$ \& F4 & F-f" \\
\hline $\begin{array}{l}\text { Tobias Hume, Captaine Hvmes Poeticall } \\
\text { Musicke (1607) }\end{array}$ & $\begin{array}{l}\text { 'The Hunting Song to be sung to the } \\
\text { Bass-Viol' (sig. } \mathrm{N}^{\mathrm{v}}-\mathrm{N} 2^{\mathrm{r}} \text { ) }\end{array}$ & $\mathrm{G} 2 \& \mathrm{C} 2$ & $g-b ”$ \\
\hline \multirow[t]{5}{*}{$\begin{array}{l}\text { Alfonso Ferrabosco II, Ayres: by Alfonso } \\
\text { Ferrabosco (1609) }\end{array}$} & $\begin{array}{l}\text { 14. Third part. Sing the nobles of his } \\
\text { race }\end{array}$ & $\mathrm{C} 4$ & $c-g$ \\
\hline & 20. Third part. Yes were the loues & $\mathrm{C} 4$ & B-g' \\
\hline & 21. So beautie on the waters flood & $\mathrm{C} 3$ & g-g' \\
\hline & 22. Had those that dwell & $\mathrm{C} 3$ & $f-a^{\prime}$ \\
\hline & 23. If all the ages of the earth & $\mathrm{C} 3$ & g-a' \\
\hline Robert Dowland, A Mvsicall Banqvet (1610) & 17. Se di farmi morire & $\mathrm{C} 4$ & $d-f^{\prime}$ \\
\hline \multirow{4}{*}{$\begin{array}{l}\text { William Corkine, Ayres, to Sing and Play to } \\
\text { the Lvte and Basse Violl (1610) }\end{array}$} & 1. Sinke downe prowde thoughts & $\mathrm{C} 3$ & $e-a b^{\prime}$ \\
\hline & 4. If streames of teares & $\mathrm{C} 3$ & $d-g^{\prime}$ \\
\hline & 5. Sweete sweete Let me goe & $\mathrm{C} 3$ & $c-a^{\prime}$ \\
\hline & 8. Vaine is all this worlds contention & $\mathrm{C} 3$ & $f-g^{\prime}$ \\
\hline \multirow{7}{*}{$\begin{array}{l}\text { William Corkine, The Second Booke of Ayres } \\
\text { (1612) }\end{array}$} & 1. Each louely grace & $\mathrm{C} 3$ & e-g' \\
\hline & 3. Two Louers sat lamenting & $\mathrm{C} 3$ & $f \sharp-g{ }^{\prime}$ \\
\hline & $\begin{array}{l}\text { 5. Deere, though your minde stand so } \\
\text { auerse }\end{array}$ & $\mathrm{C} 3$ & $f \sharp-a^{\prime}$ \\
\hline & 7. Downe, downe proude minde & $\mathrm{C} 3$ & $d-g^{\prime}$ \\
\hline & $\begin{array}{l}\text { 12. Man like a Prophet of ensuing } \\
\text { yeeres }\end{array}$ & $\mathrm{C} 3$ & $d-d^{\prime}$ \\
\hline & $\begin{array}{l}\text { 14. Away, call backe what you haue } \\
\text { said }\end{array}$ & $\mathrm{C} 3$ & $c-g^{\prime}$ \\
\hline & 15. When I was borne & $\mathrm{C} 3$ & $e-a^{\prime}$ \\
\hline $\begin{array}{l}\text { George Mason and John Earsden, The Ayres } \\
\text { that vvere Svng and Played, at Brougham } \\
\text { Castle in Westmerland, in the Kings } \\
\text { Entertainment (1618) }\end{array}$ & $\begin{array}{l}\text { 4. Come follow me my wandring } \\
\text { mates }\end{array}$ & F4 & $F-c^{\prime}$ \\
\hline
\end{tabular}

1560 s, described as 'the singularest player on the lute $[\ldots]$ whereunto he sings very well'. ${ }^{81}$ The lute songs themselves add further support to the observation that men and women alike sang these songs since their texts unambiguously express thoughts and desires from both gender perspectives. Yet numerous 'male' and 'female' songs could be cited which show either no or only negligible differences from one another in terms of clef and registral range - an observation that acquires further significance in the songs scored

\footnotetext{
${ }^{81}$ See Joseph Stevenson, ed., Calendar of State Papers Foreign: Elizabeth, iv (1561-1562) (London: Her Majesty's Stationery Office, 1866), 155, 330, 343 (entry 568.4). See also Katherine Butler, Music in Elizabethan Court Politics (Woodbridge: The Boydell Press, 2015), 198-201.
} 


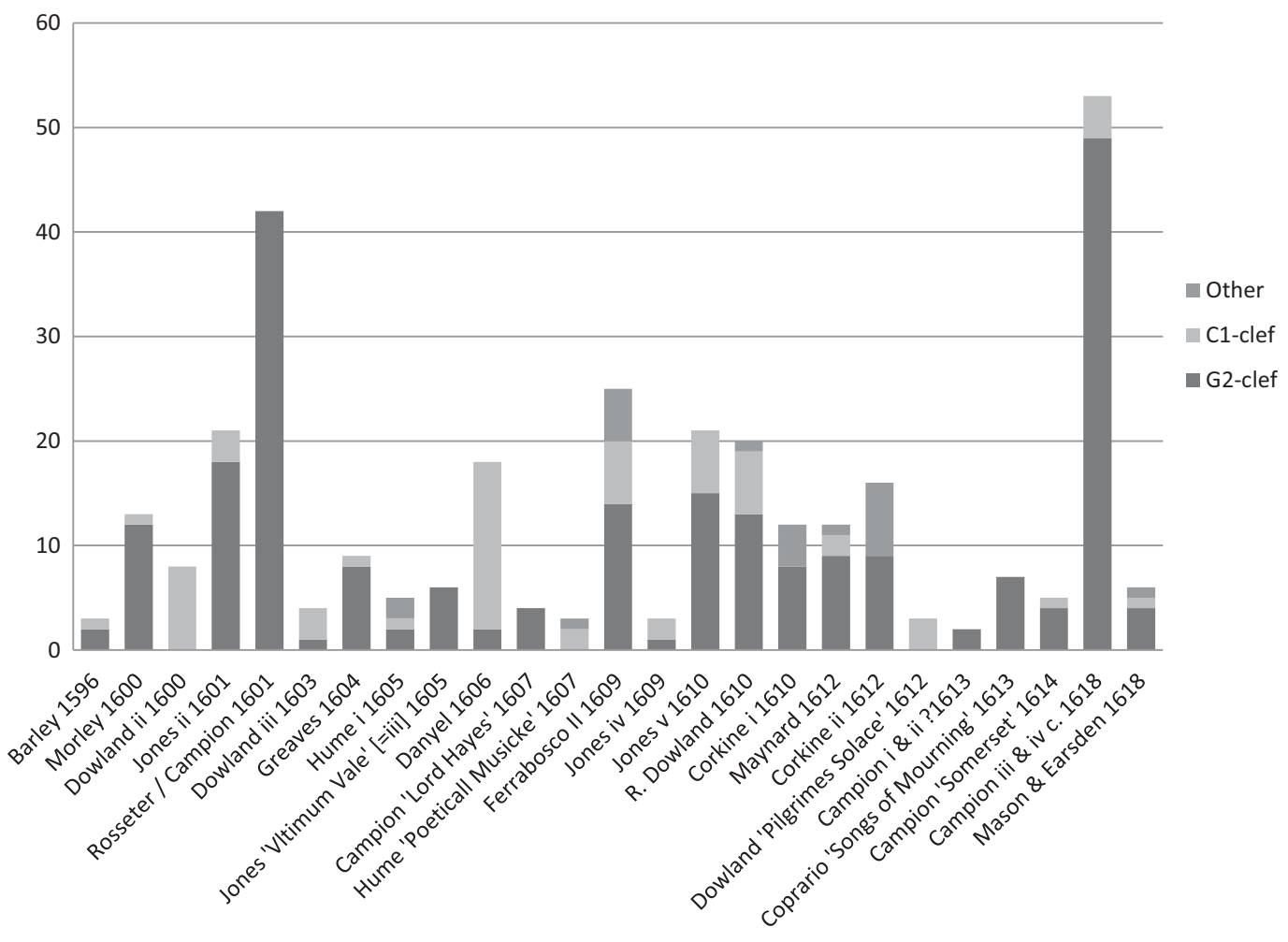

Figure 1. Clefs used in the printed lute songs scored for solo voice.

These figures exclude the first song from Campion, The Discription of a Maske [...] in honour of the Lord Hayes (which has a tenor part at the back of the book) and the incomplete song (no.14) from Thomas Morley, The First Booke of Ayres (London, 1600). "Other" includes songs in C2, C3, C4 and F4-clefs alongside three songs in the collections of Tobias Hume that use a mix of clefs.

for solo voice, like the male and female character studies (written in the first person from the perspective of the character) in The XII. Wonders of the World (1612) by John Maynard (bap. 1577-c.1633). ${ }^{82}$ This raises the critical question of the register in which men would have performed these songs: the high register as written using falsetto voice (or loft register), or an octave below sung in chest voice (or modal register). ${ }^{83}$

\section{The tenor voice and the lute song}

Judged purely on the music itself, the 'tenor' voice - or, more accurately, a man singing the treble melody down an octave in his 'natural' modal register in chest voice (i.e. high tenor, tenor, or baritone depending on the song in question) - clearly represents a plausible solution to the registral 'problem' of the male voice. ${ }^{84}$ Indeed, most of the songbooks have ranges whose upper notes extend up to $\mathrm{g}^{\prime \prime}$, sometimes

\footnotetext{
${ }^{82}$ Maynard, The XII. Wonders of the World; for example, 'The Marryed man' (song 9, G2-clef, d'- $\mathrm{f}^{\prime \prime}$ ) has a higher range than its paired song 'The Wife' (song 10; G2-clef, $\mathrm{c}^{\prime}-\mathrm{eb}^{\prime \prime}$ ). For an example of identical ranges ( $\mathrm{d}^{\prime}$ to $\mathrm{d}^{\prime \prime}$ ) and clef (G2) but different (male v. female) perspectives, see Campion, The Third and Fovrth Booke of Ayres, iii, songs 1 ('Oft haue I sigh'd for him that heares me not') and 2 ('Now let her change and spare not').

${ }^{83}$ Singers still frequently refer to 'head' and 'chest' register due to where vibrations are felt in their body; scientifically speaking, however, the changes in sound are to do with vocal fold function; see Christina Shewell, Voice Work: Art and Science in Changing Voices (Chichester: Wiley-Blackwell, 2009), 174.

${ }^{84}$ This follows generic contemporary usage of the term 'tenor' as a midrange voice between treble and bass, as in Thomas Granger, A Familiar Exposition or Commentarie on Ecclesiastes (London: Thomas Snodham, 1621), 54 (on Ecclesiates 2:8). The
} 


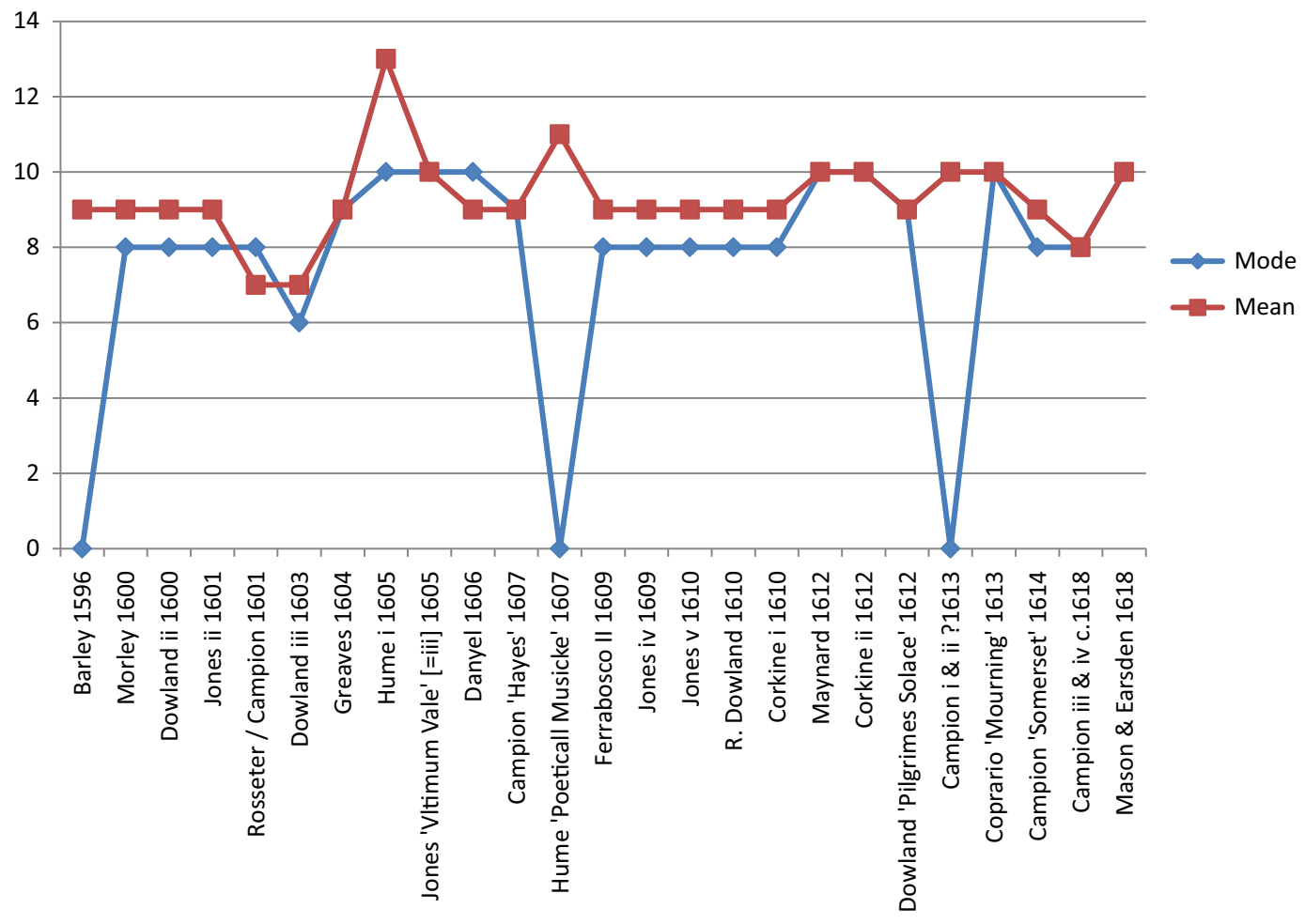

Figure 2. Average written range of sung melody in the printed lute songs for solo voice.

The numbers in the vertical axis relate to the average range in intervals (e.g. $8=$ octave; $9=$ minor or major 9 th, etc.). The mean was calculated correct to the nearest semitone. In the collections with a mode of zero, this indicates that there is no mode (i.e. no clef is more common than any other in the solo songs in this collection). The transposing songs in this collection have been analyzed as written (i.e. the sung melody has not been transposed in the above data); see Table 2.

even $\mathrm{a}^{\prime \prime}$. Important context is provided here by Thomas Morley, who explains in his A Plaine and Easie Introdvction to Practicall Mvsicke (1597/1608) that 'all songes made by the Musicians, who make songs by discretion' are set either in the 'high key' or 'lowe key' and have fixed clefs and ranges. Yet crucially, he then discusses 'compositions for men onely to sing' which, he says, 'neuer passe this compasse' accompanied by written-out ranges for four voices, the highest of which only goes up to $\mathrm{g}^{\prime}$ - and that 'you must not suffer any part to goe without the compasse of his rules, except one note at the most aboue or below' (i.e. $\mathrm{a}^{\prime}$ ). In addition, the 'Tenor' of songs 'in the high key' reaches up to $\mathrm{a}^{\prime}$ whilst the 'Tenor secundus' of 'compositions for men onely' extends down to Bb (see Figure 3).$^{85}$ Thus, in short, if the lute songs are sung down an octave by a man in tenor register, they match precisely Morley's stipulations as outlined here.

A number of hints emerge from the printed song books with tablature that collectively point towards men singing the melody an octave below the written treble pitches. The first clue comes from the handful of songs with bandora accompaniment in A Nevv Booke of Tabliture (1596) by William Barley (?1565-1614). ${ }^{86}$ Surviving evidence suggests that the bandora was particularly linked to the adult male voice in solo songs, which perhaps reflects the instrument's 'deepe'- or 'base'-sounding

word 'baritone' was virtually unknown in Elizabethan England and, unlike today, was simply used as another word for a 'bass' voice; see Dowland, Andreas Ornithoparcvs His Micrologvs, ii, 47 and iv, 84.

${ }^{85}$ Morley, A Plaine and Easie Introdvction, iii, 165-6.

${ }^{86}$ Barley, A Nevv Booke of Tabliture, iii (bandora), sig. $\mathrm{C} 2{ }^{\mathrm{v}}-\mathrm{D} 2{ }^{\mathrm{r}}$. On the bandora and its meagre surviving song repertory, see Lyle Nordstrom, The Bandora: its Music and Sources (Michigan: Harmonie Park Press, 1992), 34, 37-40, 102-4. 
a. Songs 'in the high key'

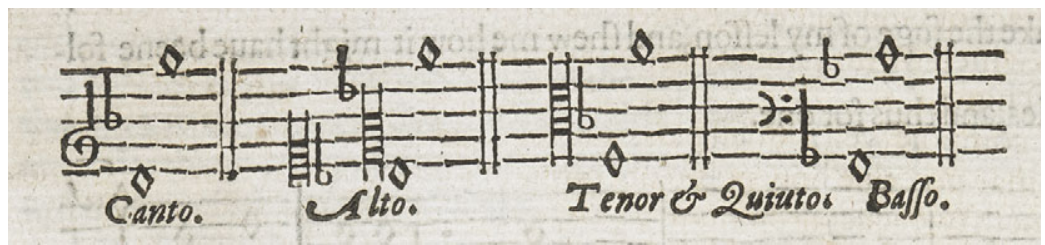

b. Songs 'in the lowe key'

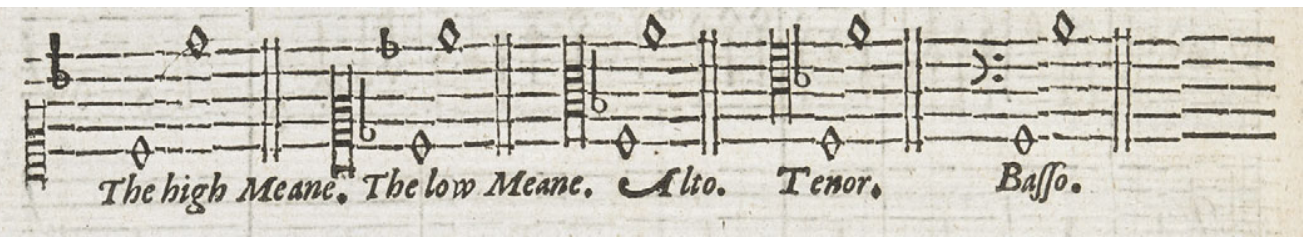

c. Compositions 'for men onely to sing'

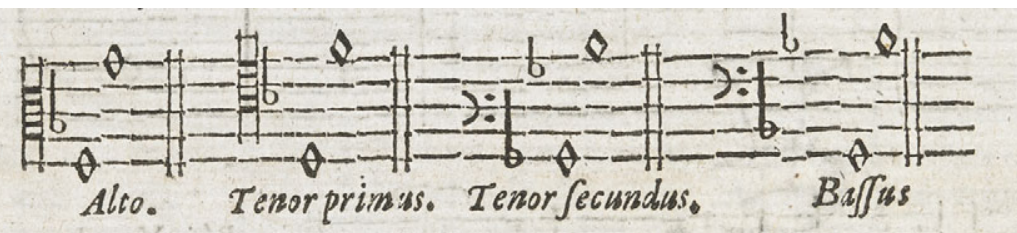

Figure 3. Ranges and clefs stipulated for use when composing 'all songes' in Thomas Morley, A Plaine And Easie Introdvction To Practicall Mvsicke (London; Humphrey Lownes, 1597), iii, 166 (British Library, Music Collections K.3.m.16.) (@ British Library Board, with permission).

register. ${ }^{87}$ Indeed, whereas a number of sources describe men playing a bandora and also singing to it, such as on several occasions in Anthony Copley's Wits Fittes and Fancies (1595), women are connected to the instrument only more passively, like listening to 'sweet musicke' on it, and references to a child singing to bandora accompaniment seem to be lacking entirely. ${ }^{88}$ Surviving archival listings add further support to this observation, since these typically indicate male ownership of bandoras. ${ }^{89}$ However, Barley's sung melodies are all in G2-clefs and C1-clefs with written ranges from $\mathrm{d}^{\prime}-\mathrm{f}^{\prime \prime}$. Even after the required downwards transposition of the melody by a fourth or fifth to resolve the different written voice and tablature pitches, ${ }^{90}$ the melody is still noticeably higher than Morley's suggested male vocal ranges - an observation that is all the more notable given Barley's close professional

\footnotetext{
${ }^{87}$ Robinson, 'A perfect-full harmonie', 207, no. 42. It was also used as a consort instrument and in solo repertory; see Spring, The Lute in Britain, 109-11 and 173.

${ }^{88}$ Anthony Copley, Wits Fittes and Fancies (London: Richard Johnes, 1595), 68, 69, 71; the quotation concerning women occurs in Joseph Swetnam, The Araignment Of Lewde, idle, froward, and vnconstant women (London: Edward Allde, 1615 ), 38. A notable exception occurs in Cyril Tourneur, Lavgh and lie dovvne (London: William Jaggard, 1605), sig. C $\mathrm{C}^{\mathrm{r}}$, an exaggerated comical description where a woman 'sings' ('like a Pigge, running to a swill-tubbe') to a 'Bandore', but even here, it is played (or rather 'fumbled') by a man.

${ }^{89}$ See 'Records of Early English Drama'. Two exceptions occur in the will of Susan Jefferies (Norwich, 1619) - who had in fact inherited the instruments from her husband Edward, a musician - and the disbursements for Mary Somerford (Somerford, 1598), later wife of Philippe Oldfield and dedicatee of a galliard by Francis Pilkington (1565-1638) in British Library, Add. MS 31392, fol. 22 $2^{\mathrm{v}}-23^{\mathrm{r}}$; see David Galloway, ed., Records of Early English Drama: Norwich 1540-1642 (Toronto: University of Toronto Press, 1984), 157, 160, 192, and Lawrence M. Clopper and David Mills, eds., Records of Early English Drama: Chester (Toronto: University of Toronto Press, 2007), 835.

${ }^{90}$ The cantus is a fourth higher than the tablature in 'Those eies which set my fancie on a fire' and 'But this \& then no more it is my last of all', whilst the cantus is a fifth higher than the tablature in 'Howe can the tree but waste and wither away'. After
} 
relationship with Morley, having worked as his assign and printer of several of his music collections. ${ }^{91}$ Sung as written, the tablature also sounds an octave lower than one might expect (i.e. compared to the voice-tablature relationship in songs with lute accompaniment). Sung down an octave, however, the ranges clearly fit Morley's tenor and bass voice stipulations.

Hints also occur through printed songs that can be connected to known contemporary singers and musicians. Two songs are linked to Robert Hales (fl. 1583-1616), a 'Groome of her Maiesties Priuie Chamber' whose singing was admired by a number of contemporaries including Elizabeth I herself. ${ }^{92}$ Both songs exploit high clefs and ranges (if sung as written by an adult male voice): 'His golden locks' from John Dowland's The First Booke of Songes or Ayres (C1-clef, range $\mathrm{f} \#^{\prime}$ to $\mathrm{d}^{\prime \prime}$ ), which Hales seems to have performed at the Ascension Day celebrations of Elizabeth I in Westminster in $1590 ;{ }^{93}$ and Hales's own composition 'O Eyes leaue off your weeping' in Robert Dowland's A Mvsicall Banqvet (1610) (G2-clef, written range $f^{\prime}$ to $f^{\prime \prime}$ ). ${ }^{94}$ Yet the written vocal tessitura in these songs seems much less fixed once the lute tablature in A Mvsicall Banqvet is carefully examined. Here, the singer's first note is always given as a cue before each song; this is generally taken from the appropriate note in the lutenist's first chord, often an octave below the singer's written pitch (as in Hales's song). Yet significantly, in two cues in this book, the lutenist has the singer's starting note twice in his first chord (i.e. at written pitch and an octave below), but he chooses to give the singer the note an octave below as a cue, seemingly hinting at performance by a tenor voice. ${ }^{95}$ To these two songs may be added a third song, whose cue is not in the lutenist's first chord but which falls easily under his fingers, again suggesting a tenor voice since it would be easy to strike the top string here. ${ }^{96}$ Vocal cues also occur in a related collection of songs with lute tablature, arranged by Sir Edward Filmer (1565/6-1629): French Covrt-Aires, VVith their Ditties Englished (1629). ${ }^{97}$ Like Robert Dowland, Filmer always gives cues an octave below the written pitch of the sung melody. Three of these songs have the starting note twice in the first chord but, like Robert Dowland, Filmer always chooses the lower pitch as a cue (an octave lower than the cantus), again hinting at tenor performance. ${ }^{98}$

Two years after the 1590 Ascension Day celebrations of Elizabeth I, the Queen visited Sudeley Castle whilst she was on progress in Gloucestershire, where entertainments had been organized by Giles Brydges (1548-94), Third Baron Chandos (they were cancelled because of bad weather). ${ }^{99}$ Amongst those due to perform in the Shepherds' Entertainment seems to have been John Dowland (identified simply as 'Do.'), who was to accompany the character 'Cut.' - perhaps Cutter of Cotsholde or possibly

transposition, the sung melodies sound as follows: a to $b b^{\prime}$ ('Those eies'), b to $b b^{\prime}$ ('How can the tree'), and c' to c' ('But this \& then'); the remaining song ('One ioy') requires no transposition, so the melody remains $\mathrm{d}^{\prime}$ to $\mathrm{f}^{\prime}$.

${ }^{91}$ See Tessa Murray, Thomas Morley. Elizabethan Music Publisher (Woodbridge: Boydell Press, 2014), 110.

${ }^{92}$ Diana Poulton, 'The Favourite Singer of Queen Elizabeth I', The Consort, 14 (1957), 24-7; and Diana Poulton, John Dowland (London: Faber and Faber Ltd, 1972/1982), 227, 408-9.

${ }^{93}$ Dowland, The First Booke of Songes, song 18. See Poulton, John Dowland, pp. 82 and 239-40. Although likely, the connection between Hales and Dowland's 'His golden locks' should not be overstated given (a) the minor textual differences between Dowland's song and the verses sung by Hales, particularly the use of first person throughout ('My golden locks'); and (b) because Hales's performance predates the earliest surviving version of Dowland's song.

${ }^{94}$ Robert Dowland, A Mvsicall Banqvet (London: Thomas Snodham, 1610), song 3. After downwards transposition to match the lute tablature and bass viol part, the voice part actually sounds $\mathrm{eb}^{\prime}$ to $\mathrm{eb}^{\prime \prime}$.

${ }^{95}$ Robert Dowland, A Mvsicall Banqvet, songs 1 ('My heauie sprite') and 17 ('Se di farmi moriré').

${ }^{96}$ Robert Dowland, A Mvsicall Banqvet, song 18 ('Dourò dunque morire?'). I am grateful to Christopher Goodwin for drawing my attention to this piece.

${ }^{97}$ Filmer, French Covrt-Aires, sig. $\mathrm{B}^{\mathrm{r}}$ explicitly mentions these: 'The single Letter before the beginning of the Lute-part giues the Tune that the singing Part, which is ouer it, begins-in'.

${ }^{98}$ Filmer, French Covrt-Aires, songs 9 ('Syluia, not long since, halfe-affrighted'), 14 ('Reason! arme thy wrong'd hands') and 17 ('Say then! my hard Iewell').

${ }^{99}$ Elizabeth Goldring, Faith Eales, Elizabeth Clarke, and Jayne Elisabeth Archer, eds., John Nichols's The Progresses and Public Processions of Queen Elizabeth I: A New Edition of the Early Modern Sources (Oxford: Oxford University Press, 2014), iii (15791595), 609-15. I am indebted to Katherine Butler for drawing my attention to this reference. 


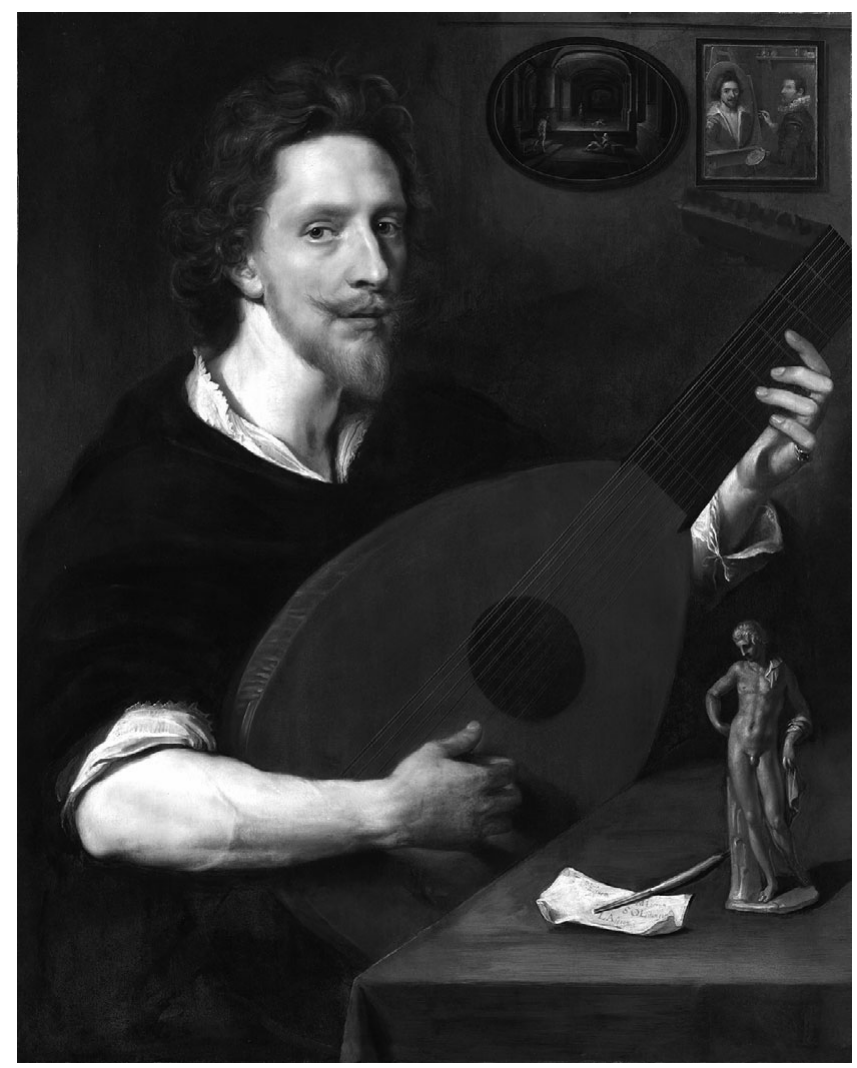

Image 6. Hendrick van Steenwyck the Younger (c.1580-1647), Painting of Nicholas Lanier (1588-1666) holding a lute (1613) (৫ Private collection, The Weiss Gallery, London, with permission).

Cutty (i.e. Cuthbert) - in the song 'Hearbes, wordes, and stones'. ${ }^{100}$ Maybe these are the same as the two musicians who on the previous day would have stood next to Apollo and performed ('one that sung [...] one that plaide', the latter on 'lute') 'My hart and tongue were twinnes', a song set by John Dowland in his A Pilgrimes Solace (1612). ${ }^{101}$ Yet if the printed song in any way resembles the one intended for the Shepherds' Entertainment, it would surely have been sung down an octave if performed by an adult male given the clef and range of its cantus part (G2-clef, range $\mathrm{f}^{\prime}$ to $\mathrm{a}^{\prime \prime}$ ).

Two known contemporary singers are also linked to Campion's 'single voyce' lute songs for the masque of the Earl of Somerset (1614). The first four numbers in this collection are respectively described as having been 'made and exprest' and 'sung' by ' $M^{r}$. Nicholas Laneir' (Image 6) and ' $M^{r}$. Iohn Allen'; yet once again, these songs are written in C1 or G2-clefs and have overall ranges of $\mathrm{d}^{\prime}$ to $\mathrm{g}^{\prime \prime} .{ }^{102}$ Although Lanier's vocal range cannot be confirmed through external evidence, the likelihood that he sang at tenor range is surely suggested by the description of his co-musician as 'that most excellent tenor voyce, and exact Singer (her Ma. ${ }^{\text {ties }}$ Servant, $\mathrm{M}^{\mathrm{r}}$. Jo. Allin)' in Ben Jonson's The Masqve of Qveenes (1609). ${ }^{103}$ Thus,

\footnotetext{
${ }^{100}$ The identity of the singing character is disputed; see Goldring et al., John Nichols's The Progresses, iii, 614 no. 61 . Poulton, John Dowland, pp. 29-30 may overstate the case in claiming 'there can be no doubt that the contraction "Do." stands for Dowland himself

${ }^{101}$ Dowland, A Pilgrimes Solace, song 18.

${ }^{102}$ Thomas Campion, The Description of a Maske [...] At the Mariage of the Right Honourable the Earle of Somerset (London: Edward Allde and Thomas Snodham, 1614), title page, sig. $\mathrm{C}^{\mathrm{v}}$ and sig. $\mathrm{C}^{\mathrm{v}}$.

${ }^{103}$ Ben Jonson, The Masqve of Qveenes, British Library Royal, MS 18 A XLV, fol. 20 . The manuscript can be accessed via: https:// www.bl.uk/collection-items/autograph-manuscript-of-ben-jonsons-the-masque-of-queens-1609. Explicit references to a tenor voice
} 
even allowing for the possibility that these songs could have been published in different versions to those heard in the masque, they clearly provide strongly suggestive evidence for a male soloist singing music written in G2 and C1-clefs down an octave in tenor register. ${ }^{104}$

A further possible hint that men sang from high clefs down an octave can be found in the few songs that exploit unusually large ranges and a variety of clefs. A pertinent example is 'Robin is a louely lad' from George Mason (fl. 1611-18) and John Earsden's (fl. 1618) ayres performed at the 1618 'Kings Entertainment' organised by Francis Clifford, Fourth Earl of Cumberland (1559-1641) in Brougham Castle, where various characters have solos in different registers (in G2, F4, and C3-clefs) before they join together for a final section and chorus in a G2-clef with a range of $\mathrm{g}^{\prime}$ to $\mathrm{g}^{\prime \prime}$ - surely intended to be sung down an octave (or even two) by the singers with F4 and C3-clef solos. ${ }^{105}$ Likewise, in the Ayres (1609) of Alfonso Ferrabosco II (c.1575-1628), two groups of three songs labelled 'First part', 'Second part', and 'Third part' demand an abnormally large overall range of 2.5 octaves from $B b$ or $c$ to g' reading from $\mathrm{G} 2$, $\mathrm{C} 1$, and C4-clefs; ${ }^{106}$ yet if the songs in $\mathrm{G} 2$ and $\mathrm{C} 1$-clefs here are sung down an octave, the overall range in each group $\left(\mathrm{c}-\mathrm{g}^{\prime}\right.$ and $\mathrm{B} b-\mathrm{g}^{\prime}$ respectively) conforms closely to the tenor ranges outlined by Morley. ${ }^{107}$

Three songs using large ranges and different clefs by Tobias Hume (c.1569-1645) - two from The First Part of Ayres (1605) and one from Captaine Hvmes Poeticall Musicke (1607) - also deserve attention here, since they are closely related in style to the repertory under discussion even though they are, strictly speaking, not lute ayres. ${ }^{108}$ Unlike the previous examples, the clefs alternate midway through both 'The Souldiers Song' (variously G2, C1, C2, and C3-clefs, with range g- $\mathrm{g}^{\prime \prime}$ and tablature for tenor viol) and 'The Hunting Song to be sung to the Bass-Viol' (variously G2 and C2-clefs, with range g-a" and sporadic tablature for bass viol). ${ }^{109}$ Both songs were presumably meant to be sung in their entirety down an octave if performed by a man, since octave downwards transposition of only the passages in G2 and C1-clefs would create odd registral breaks with the passages in C2 and C3-clefs that are surely not intended. ${ }^{110}$ When the whole melody is transposed down an octave, it not only brings the songs in line with Morley's male voice stipulations, but it also resolves the otherwise peculiar incongruity between music (i.e. treble register) and text (i.e. from the soldier's or huntsman's perspective). ${ }^{111}$ Indeed, it seems unlikely that a

occur in two of his other masques; see Ben Jonson, The Characters of Two royall Masques (London: George Eld, 1608), 'The Qveenes Masqves. The first, Of Blacknesse' (1605), sig. A4 ${ }^{\mathrm{v}}$ and B4 ${ }^{\mathrm{v}}$; and 'The Second Masqve' (1608), sig. E $\mathrm{E}^{\mathrm{r}}, \mathrm{E}^{\mathrm{v}}$, and E2 ${ }^{\mathrm{r}}$. On Lanier as a tenor, see also Michael I. Wilson, Nicholas Lanier: Master of the King's Musick (Aldershot: Scolar Press, 1994$), 138$.

${ }^{104}$ Incidentally, explicit evidence of 'tenor' participation in masque songs as a harmony part also exists; see Campion, The Discription of a Maske [...] in honour of the Lord Hayes, sig. B2 ${ }^{\mathrm{r}}-\mathrm{B} 2^{\mathrm{v}}$ ('a base, Tenor, and treble voyce' sing 'Now hath Flora'; the music is on sig. $\mathrm{D} 2^{\mathrm{v}}-\mathrm{D} 3^{\mathrm{r}}$ and sig. $\mathrm{E} 3^{\mathrm{v}}$ ). Campion also describes a dialogue sung by a 'base \& tenor' (sig. $\mathrm{D} 1^{\mathrm{v}}$ ), but the music is not included.

${ }^{105}$ Mason and Earsden, The Ayres that vvere Svng and Played, at Brougham Castle, song vi (described as 'The Dance': 'Robin is a louely Lad').

${ }^{106}$ Ferrabosco II, Ayres, songs $12-14$ and 18-20. Voice designations are absent from this collection, save the words 'Shepheard' and 'Nimph' in the 'Dialogues' at the end (songs 26-28). The first group (songs 12-14) has an overall range of c to $\mathrm{g}^{\prime}$, with the first two songs in G2-clefs and the last in a C4-clef; song 14 alone has a range of $\mathrm{c}$ to $\mathrm{g}^{\prime}$. The second group (songs 16-18) has the same wide pitch problem with an overall range of $\mathrm{Bb}$ to $\mathrm{g}^{\prime \prime}$ in $\mathrm{C} 1$ (song 18), G2 (song 19), and C4-clefs (song 20); again, song 20 alone has a range of $\mathrm{Bb}$ to $\mathrm{g}^{\prime}$.

${ }^{107}$ Morley, A Plaine and Easie Introdvction, iii, 166. Perhaps significantly, the edition of Ferrabosco II's Ayres by Fellowes, The English School of Lutenist Song Writers, series 2, vol. 16, puts all three songs in each group into the same octave (i.e. by transposing songs 14 and 20 up an octave), even though he writes in his introductory preface that the two groups 'each form a single composition, and it is remarkable that in each instance the third section is in the tenor clef and evidently intended to be sung at that pitch.'

${ }^{108}$ Hume, The First Part of Ayres, songs 1, 114 and Hume, Captaine Hvmes Poeticall Musicke, 'The Hunting Song to be sung to the Bass-Viol' (sig. $\mathrm{N}^{\mathrm{v}}-\mathrm{N} 2^{\mathrm{r}}$ ).

${ }^{109}$ A possible G2-clef omission in the middle of 'The Hunting Song' on the words 'Harke Beuty Dainty' would actually make the highest note $\mathrm{b}^{\prime \prime}$; I am grateful to John Milsom for this observation.

${ }^{110} \mathrm{~A}$ boy treble performance as written is also theoretically possible, given that Philip Massinger, The Pictvre A Tragoecomoedie (London: I. N., 1630), Act 2, scene ii, sig. E4 ' describes 'two Boyes, one with his lute, the other like Pallas' who sing 'A song in the prayse of souldiers, especially being victorious'. However, this would require a boy who could go as low as g (i.e. lower than standard treble ranges given by contemporaries, as discussed previously).

${ }^{111}$ Morley, A Plaine and Easie Introdvction, iii, 166. 
man singing the songs as written (in falsetto, reaching up to $\mathrm{g}^{\prime \prime}$ ) could really convey with any gravitas for contemporaries the 'wel gotten skars' of battle 'the brauery of glittring shields', and the 'shoutes and soundes of hornes and houndes' mentioned in the songs, particularly given Hume's first-hand experience as a soldier. ${ }^{112}$

The third song, 'Alas poore men' (variously G2, C1, C3, C4, and also F4-clefs, with range F- $\mathrm{f}^{\prime \prime}$ and bass viol tablature), is slightly more problematic, since the F4-clef section would be too low if the whole song is transposed down an octave. ${ }^{113}$ As it stands, its three-octave range exceeds by some way any other contemporary English music for solo voice, even outstretching works written several decades after 1650 for the bass John Gostling (1644-1733), who was famed for his low notes and had a range of at least two octaves $\left(\mathrm{D}-\mathrm{d}^{\prime}\right) .{ }^{114}$ Likewise, other songs with large ranges from elsewhere in Europe $c .1600$ - notably in Italy by composers such as Ottavio Valera (early seventeenth century) and Giulio Caccini (1551-1618) are markedly different in character and style from Hume's song, instead showcasing vocal virtuosity and utilizing many fast runs. ${ }^{115}$ Thus, if 'Alas poore men' really was intended for performance as written by one singer, ${ }^{116}$ how was he supposed to convey an appropriately sombre mood in its execution, as befitting the song's accompanying performance instructions which clearly convey its serious nature as an 'Imitation of Church Musicke'?117 Likewise, given that English theoretical writings on music c.1600 considered the 'naturall compasse of mans voice' to be between 'an Interuall by a Fifteenth' and 'xx. notes and no more', how could printing the song have represented a sensible marketing decision, especially from a printer like John Windet ( $f$. 1584-1611) who had an established reputation? ${ }^{118}$ Perhaps the F4-clef section was to be sung at pitch whilst the G2 and C-clef sections were to be transposed (as in the previous examples); in any case, the song clearly represents an unusual and exceptional conundrum.

\footnotetext{
${ }^{112}$ Contemporaries unambiguously convey their unease at the mismatch of (masculine) military service and the (more feminine) art of music-making; for example, see Humfrey Barwick, A Breefe Discourse, Concerning the force and effect of all manuall weapons of fire (London: Edward Allde, ?1592), sig. B3 ${ }^{\mathrm{r}}$, where 'one Cornelius a Gentleman and a Souldiour in the French Kings seruice', despite his facility on the 'Lute' and 'Gitterne', would not even play for the 'best Lord or Lady in Fraunce' for fear of being taken for 'some foolish Musition'; see also Appendix 2 doc. 33. On Hume, see Michael Rossi, “'Musical Humors": The life and music of Captain Tobias Hume, gentleman', Defining Strains: The Musical Life of Scots in the Seventeenth Century, James Porter, ed. (Oxford, Bern, etc.: Peter Lang, 2007), 155-80. Incidentally, the melody of a textually related song in Maynard, The XII. Wonders of the World, song 3 ('The Souldiour') is also written in a G2-clef, with the written sung range $\mathrm{g}^{\prime}-\mathrm{a}^{\prime \prime}$. The same problems of textual-musical incongruity occur if it is sung by a man at the written octave; how could this seriously convey for contemporaries a line such as 'My Occupation is the Noble trade, the trade of Kings', etc.?

${ }^{113}$ Hume, The First Part of Ayres, song 114. See the male ranges in Morley, A Plaine and Easie Introdvction, iii, 166. Praetorius, Syntagma Musicum, ii, 17, notes that 'most basses in the schools' ('Die gemeine Bassisten [...] in Schulen') can rarely descend below F or E (at the bottom of the bass clef) 'in proper natural strength' ('in rechter natürlicher stärke'), although he strangely seems to suggest lower ranges that go beyond $\mathrm{C}$ and even reach FF in his 'Tabella' of voice ranges (ibid., ii, p. 20). On modern classical bass ranges, see Dan H. Marek, Singing. The First Art (Lanham and Toronto: The Scarecrow Press, 2007), 117, 120-2.

${ }^{114}$ For example, see 'Music's the Cordial of a troubled Breast' (range D-d') from the ode 'Begin the Song!' by John Blow (1649-1708) in A Second Musical Entertainment Perform'd On St. Cecilia's day. November XXII. 1684 (London: John Playford, 1685), 54-63.

${ }^{115}$ See Ottavio Valera's 'Sfogava con le stelle' in Francesco Rognoni, Selva De Varii Passaggi (Milan: Filippo Lomazzo, 1620), ii, 72-3 (range C- $\mathrm{c}^{\prime \prime}$ ) and 'Io che l'eta solea' and 'Deh chi d'alloro' in Giulio Caccini, Nvove mvsiche e nvova maniera di scriverle (Florence: Zanobi Pignoni, 1614), 33-38 (these two songs are specified 'per Tenore, che ricerchi le corde del Basso'). Other Italian evidence documents how bass singers like Giulio Cesare Brancaccio (1515-86) practised 'multi-register' singing, whilst a famous letter of 1562 by Giovanni Camillo Maffei (fl. 1562-73) describes how some men could 'very easily sing in the bass, tenor, and any other voice'; see Richard Wistreich, Warrior, Courtier, Singer: Giulio Cesare Brancaccio and the Performance of Identity in the Late Renaissance (Abingdon: Routledge, 2007/2016), 181-182, 193-217.

${ }^{116}$ See Fellowes, The English School of Lutenist Song Writers, series 2, xxi, 46.

${ }^{117}$ Hume, The First Part of Ayres, song 114, sig. Q2 ${ }^{\mathrm{r}}$. Nothing suggests it is intended as a comical or technical showpiece; note how it is described - with 'melancholy lyrics' and 'sombre minimalist accompaniment' - in the novel by Michel Faber, The Courage Consort: Three Novellas (Orlando: Harcourt Books, 2005), 'The Courage Consort', 1-96 (pp. 88-9).

${ }^{118}$ The quotes are taken respectively from Dowland, Andreas Ornithoparcvs His Micrologvs, i, 21-2; and Morley, A Plaine and Easie Introdvction, i, 7 and iii, 166. Windet produced other music books including Thomas Sternhold and John Hopkins's The Whole Booke of Psalmes (1599), John Dowland's Lachrime (1604), and the lute song books by John Coprario (1606), John Bartlet (1606), and Thomas Ford (1607).
} 
Within the context of all the hints described above in the songbooks for men singing from high clefs an octave below, Campion's observation in his Tvvo Bookes of Ayres (?1613) that 'the Treble tunes, which are with us commonly called Ayres, are but Tenors mounted eight Notes higher' surely acquires significance. ${ }^{119}$ More crucially, in his singing instruction manual in The Schoole Of Mvsicke (1603), Thomas Robinson (c.1560-1610) - after discussing the 'Gam-vt' and its relationship to tablature explicitly incorporates singing 'eight vnder' into his definition of singing 'with the Lute in the vnison':

'Now you haue gotten the way to tune your voice, (note for note) with the Lute in the vnison, (that is: all in one tune or sound, or eight vnder) then you may rule your voice to the Viol also ... '120

Francis Bacon (1561-1626) likewise notes in his Sylva Sylvarvm (1627) that the 'Diapason or Eight in Musicke [...] is in effect an Vnison', as in bass courses on lutes tuned 'one an Eight aboue another; Which make but as one Sound'. ${ }^{121}$ Additional related evidence further substantiates contemporary performance of lute song melodies an octave below the written pitches by a tenor or baritone voice. ${ }^{122}$ Yet what about a man singing the songs at the written pitch using falsetto voice (or loft register) and only occasional modal register for lower notes? (Image 7).

\section{The male falsetto voice and the lute song}

According to Michael Praetorius (1571-1621), the 'falsetista' of Continental polychoral music had the same range as the 'Evnuchus' and 'Discantista', that is from b or c' to somewhere between $\mathrm{e}^{\prime \prime}$ and $\mathrm{a}^{\prime \prime}{ }^{123}$ Praetorius therefore primarily considered the falsetto voice to be a soprano voice (not alto, as it is typically used today). This 'male soprano' range is clearly sufficient to execute the cantus parts of lute songs as written, assuming the full upper range up to $\mathrm{a}^{\prime \prime}$ is usable (which, incidentally, is usually not the case for modern countertenors or falsettists apart from specialist sopranists). ${ }^{124}$ The word 'falsetto', however, appears to have been virtually unknown in England: it only seems to occur in the 1598 and 1611 Italian-English dictionaries of John Florio (1553-1625), who defines it as 'a false treble or counter-tenor in musicke'. ${ }^{125}$ Florio's phrase 'false treble' also seems to be absent from other English sources until later on. ${ }^{126}$ The Italianate context of this source is

\footnotetext{
${ }^{119}$ Campion, Tvvo Bookes of Ayres, i, 'To the Reader' [sig. A ${ }^{\mathrm{v}}$ ].

${ }^{120}$ Thomas Robinson, The Schoole Of Mvsicke (London: Thomas East, 1603), sig. $\mathrm{N}^{\mathrm{r}}$.

${ }^{121}$ Francis Bacon, Sylva Sylvarvm: or A Naturall Historie In ten Centuries (London: John Haviland and Augustine Mathewes, 1626 [ =1627]), Century ii, 36.

${ }^{122}$ Several decades later, John Playford (1623-1686/7) explained that he had avoided C-clefs in The Second Book of the Pleasant Musical Companion (London: John Playford, 1686) and had instead 'Printed them all in the G, or Treble Cliff, as proper to be Sung by Men or Boys'. He also notes that he could have printed his four-voice Psalms using three treble clefs and a bass clef, since it was 'usual and common for Men to Sing those Songs which are prick'd in a Treble an Eighth lower, where the Parts are so Composed, that they do not interfere with the Bass'; cited in Matthew Locke, The Present Practice Of Musick Vindicated (London: N. Brooke, 1673), 86. The opposite solution occurs in Matthew Parker, The vvhole Psalter translated into English Metre, which contayneth an hundreth and fifty Psalmes. The first Quinquagene (London: John Daye, ?1567). Here, the nine tunes by Thomas Tallis (1505-85), written in four voice parts, carry the observation (sig. W.iv ${ }^{r}$ ): 'The Tenor of these partes be for the people when they will syng alone, the other parts, put for greater queers, or to suche as will syng or play them priuatelye'; these tenor parts are all in a C4-clef. 'People' surely includes women and children here reading this clef up an octave; see Marsh, Music and Society in Early Modern England, 407-8.

${ }^{123}$ Praetorius, Syntagma Musicum, ii, sig. Cii ${ }^{v}$ (= p. 20), Tabella iv (Vox viva seu humana).

${ }^{124}$ Modern countertenors typically have ranges from around $\mathrm{g}$ to $\mathrm{d}^{\prime \prime}$ or $\mathrm{e}^{\prime \prime}$. Around half of the entire surviving printed lute songs reach $\mathrm{f}^{\prime \prime}$ or higher and are therefore problematic as written for countertenors whose highest usable note is $\mathrm{e}^{\prime \prime}$. Scholars give slight variations for modern countertenor ranges and generally do so within the context of later music, where greater ranges are required; compare John Barry Steane, 'Countertenor', The New Grove Dictionary of Opera, ed. Stanley Sadie (London: Macmillan Press Limited, 1992), i, 999 and Marek, Singing. The First Art, 123.

${ }^{125}$ Florio, A Worlde of Wordes, 124; John Florio, Qveen Anna's New World of Words, Or Dictionarie of the Italian and English tongues (London: Melchior Bradwood and William Stansby, 1611), 178. The phrase 'false treble' seems to have been rare.

${ }^{126}$ See Thomas Brown, The Whole Comical Works of Mons ${ }^{r}$. Scarron (London: S. And J. Sprint, 1700), i, ch. ii, 3-4 and ii, ch. vii, 173 .
} 


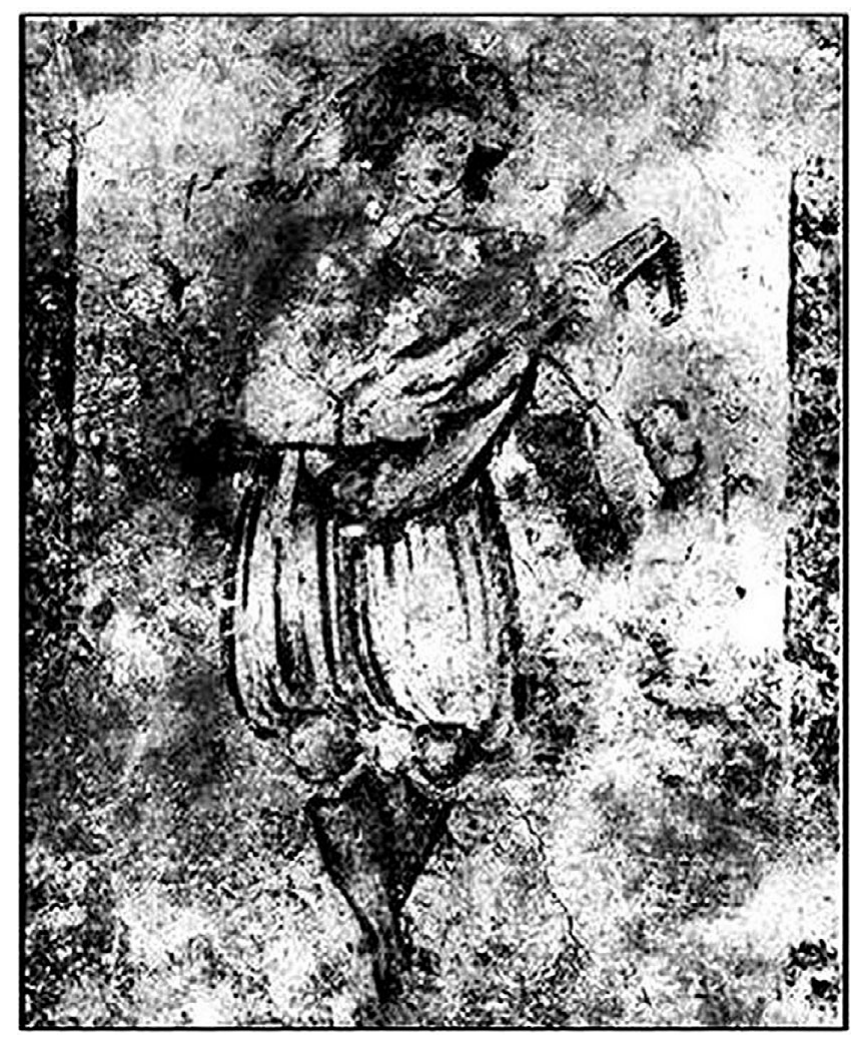

Image 7. Anonymous (c.1615), Wall painting of lute player, originally in a bedroom in the west wing of The Swan Inn, No.1 London End, Beaconsfield, now in Aylesbury Museum (৫ Bucks Free Press, with permission).

thus noteworthy, since falsetto singing seems to have been known in Italy, as famously described by the English traveller Thomas Coryat (c.1577-1617) on his travels to Venice in $1608 .{ }^{127}$

Similarly, the modern association of male falsetto singing with the word 'countertenor' (which Florio could appear to substantiate) seems not to reflect general usage in England at this time, which may indicate Florio's difficulty in finding a clear definition for 'falsetto'. ${ }^{128}$ The word 'countertenor' normally occurs alongside various combinations of 'treble', 'mean', 'tenor', and 'bass' in contexts ranging from choirs to bell sizes and forest birds; ${ }^{129}$ its primary function as a part name is underlined through conflation with terms like 'contra-tenor', 'counterbase', and 'counterpoynt'. ${ }^{130}$ Only one source - Campion's

\footnotetext{
${ }^{127}$ See Parrott, 'Falsetto beliefs', 93. Even abroad, falsetto singing was not always mentioned positively, and it may not have been as widely used as is sometimes supposed; see Richard Wistreich, 'Reconstructing Pre-Romantic Singing Technique', The Cambridge Companion to Singing, ed. John Potter (Cambridge: Cambridge University Press, 2000), 178-91 (p. 180).

${ }^{128}$ See also Florio's definition for 'Mezzano' as 'a meane or countertenour in musicke or singing' in A Worlde of Wordes, 225.

${ }^{129}$ For representative examples (many could be cited), see Thomas Adams, The Happines of the Church (London: G. P., 1619), 'Faiths Encovragement', 413-16 (bells); Thomas Scot, Philomythie, or, Philomythologie (London: Francis Constable, 1622), sig. K3 ${ }^{\mathrm{v}}$ (choir); and William Browne, Britannia's Pastorals. The first Booke (London: John Haviland, 1625), i, 65 (birds). A small handful of sources mention 'countertenor' on its own, several of which exploit puns on the 'counters' of bankers and relate to those residing in prison for debt, like Donald Lupton, London and the Countrey Carbonadoed and quartred into Seuerall Characters (London: Nicholas Okes, 1632), 42-6 (p. 45).

${ }^{130}$ For example, see Peter Hay, A Vision Of Balaams Asse (London: Eliot's Court Press, 1616), 69 (counterbase); Thomas Becon, The Reliques of Rome (London: John Day, 1563), fol. $121^{\mathrm{v}}$ (counterpoynt); Henry Hawkins, Partheneia Sacra (Rouen: John Cousturier, 1633), 146 (counter, counter-alt); Michael Drayton, Poems: By Michaell Draiton Esquire (London: Valentine Simmes, 1605), sig. Bb2 ${ }^{\mathrm{v}}$, Sonnet 6 (counterchime). Incidentally, 'countertenor' occasionally meant a lower voice than the tenor;
} 
description of the 1613 entertainment at Reading for Anne of Denmark (1574-1619) given by Lord Knowles - apparently describes a 'counter-tenor voice' in music that may have resembled the lute song. ${ }^{131}$ Its accompaniment by 'two vnusuall instruments', however, may suggest a specific intended effect here; perhaps this 'counter-tenor voice' sang a harmony part (like the altus) instead of the melody. ${ }^{132}$ More significantly, the only example of a contratenor in Campion's lute song books is actually written in a C3-clef with the range $d$ to $f^{\prime} .{ }^{133}$ This range is not only virtually identical to other tenor parts in Campion's songs, ${ }^{134}$ but it also matches exactly two of the tenor ranges stipulated by Morley in A Plaine and Easie Introdvction: the 'Tenor' in the 'low key' and the 'Tenor primus' in the 'compositions for men onely to sing' (both in C4-clef, range d-f' $).{ }^{135}$ The 'counter-tenor voice' Campion describes in the 1613 entertainment was thus probably a high tenor, not a falsettist. ${ }^{136}$ Further support for this reading may be found in Le Roy's description of lute strings ('the high Tenour, called in Latine Contratenor [...] is nexte to the highest, or Treble') and Dowland's translation of Micrologvs ('the high Tenor, is the vppermost part, saue one of a Song'), amongst others. ${ }^{137}$ Indeed, this meaning of 'countertenor' most likely derives from the term's origins in late medieval music, where the 'contratenor' originally occupied a similar range to the 'tenor' and was later subdivided into 'contratenor altus' and 'contratenor bassus' respectively. ${ }^{138}$

Lastly, it is important briefly to address the 'Evnuchus' mentioned by Praetorius. Although known to English readers through literary texts, the eunuch represented something theoretical, not real, in English society, as exemplified by those sources that refer to the Biblical passage in Acts 8 where Philip the Evangelist met the Ethiopian eunuch; ${ }^{139}$ indeed, actual English contact with eunuchs was seemingly had solely by English ambassadors abroad. ${ }^{140}$ Only a tiny handful of English sources mention a eunuch singing to a lute, a character that is primarily used to conjure up exotic authenticity in ancient and foreign settings. ${ }^{141}$ Unlike in Continental princely chapels, ${ }^{142}$ eunuchs seem not to have been employed in English royal or ecclesiastical choirs, nor are they apparently mentioned in descriptions of actual English music-making - a fact exemplified by the letters of Richard Champernoun of Modbury (c.1558-1622) to Sir Robert Cecil (1563-1612) in 1595, in which he fiercely denied 'an ydle \& vntrew

see Samuel Purchas, Pvrchas His Pilgrimes. In Five Bookes [...] The Third Part (London: William Stansby, 1625), i, ch. 10, 181 (from Gaspar da Cruz's account of his travels in China), which describes an ensemble using 'two small Bandoraes for the Tenor, a great one for counter-Tenor', amongst other instruments.

${ }^{131}$ Thomas Campion, A Relation Of The Late Royall Entertainment Given By The Right Honorable The Lord Knovvles... (London: William Stansby, 1613), sig. B' ('this Song was sung by an excellent counter-tenor voice, with rare varietie of diuision vnto two vnusuall instruments'). See Ravens, The Supernatural Voice, 87-8.

${ }^{132}$ As suggested on the title pages of Dowland, The First Booke of Songes, and Jones, The First Booke of Songes.

${ }^{133}$ Campion, Tvvo Bookes of Ayres, ii, song 3 ('Harden now thy tyred hart').

${ }^{134}$ For example, see Campion, Tvvo Bookes of Ayres, i, songs 1 ('Avthor of light') and 9 ('Most sweete and pleasing'), whose tenor parts both use a C3-clef and have a range of $\mathrm{d}$ to $\mathrm{g}^{\prime}$.

${ }^{135}$ Morley, A Plaine and Easie Introdvction, iii, 166.

${ }^{136}$ Earlier in Campion, A Relation Of The Late Royall Entertainment, sig. A4 ${ }^{\mathrm{r}}$, a five-part song is also incidentally described where two characters 'sing two Countertenors' (the others sing 'two Trebles' and 'the Base').

${ }^{137}$ Le Roy, A briefe and plaine Instruction, p. ${ }^{\mathrm{r}}$; Dowland, Andreas Ornithoparcvs His Micrologvs, iv, 84. See also John Taylor, The Nipping Or Snipping Of Abvses (London: Ed. Griffin, 1614), sig. K3 ${ }^{\mathrm{v}}$ (Epigram 30), where 'the Tenor' is linked to 'the cursed Counter booke'.

${ }^{138}$ See Don Michael Randel, ed., The Harvard Dictionary of Music: Fourth Edition (Cambridge, Massachusetts: Harvard University Press, 1986/2003), 212 ('Contratenor').

${ }^{139}$ For a representative example, see Lancelot Andrewes, Scala Coli. Nineteene Sermons Concerning Prayer (London: Nicholas Okes, 1611), p. $244^{\mathrm{v}}$.

${ }^{140}$ See Agostino Nani's 1601 ( = 1602) letter to the Doge and the Senate sent from Constantinople, describing how the 'English Ambassador' had presented a note to the 'Chief Eunuch' about a Spanish naval attack, in Horatio F. Brown, ed., Calendar of State Papers and Manuscripts, Relating To English Affairs, existing in the Archives and Collections of Venice, and in other Libraries of Northern Italy, ix (1592-1603) (London: Her Majesty's Stationery Office, 1897), 495 (entry 1055).

${ }^{141}$ George Whetstone, An Heptameron of Ciuill Discourses (London: Richard Jones, 1582), sig. $\mathrm{Ci}^{\mathrm{v}}$, sig. Hiv ${ }^{\mathrm{v}}$, sig. Miv ${ }^{\mathrm{r}}$, sig. $\mathrm{Piv}^{\mathrm{r}}$, sig. S.ii ${ }^{\mathrm{v}}$, and sig. $\mathrm{Xi}^{\mathrm{r}}$; and Gervase Markham, The most Famous and renowned Historie, of that woorthie and illustrous Knight Meruine (London: R. Blower and Valentine Simmes, 1612), 65. A couple of other English sources mention a eunuch singing to a harp or unnamed instrument.

${ }^{142}$ See Praetorius, Syntagma Musicum, ii, 17 and iii, 82. 
report of mee as a gelder of boyes for preserving theyr voyces', noting that such action would be 'agaynst reason, \& the law'. ${ }^{143}$ More importantly, eunuchs were generally believed to represent an odd middle gender ('lesse then a man, \& halfe a woman'), ${ }^{144}$ and were seen as 'vnperfect', 'effeminate', and 'womanish'. ${ }^{145}$ These negative assessments link to more general contemporary suspicion aroused by effeminate men, who were considered to 'have degenerated into women' and thus to have transformed 'from the more perfect to the imperfect'; ${ }^{146}$ indeed, he who 'hath the voyce lyke a woman, is estemed of the wise to haue litle vnderstanding or knowledge' - something that the aspiring courtly amateur male musician could hardly think it worth emulating. ${ }^{147}$

On the face of it, therefore, evidence for the falsetto voice in the lute song appears to be absent. Nevertheless, the possibility that contemporary Englishmen used different terminology to ours to mean falsetto singing remains open. Indeed, the vocabulary used c.1600 to describe spoken and sung voices reveals slight differences between Elizabethan and modern English, and careful analysis is required to unravel the subtle nuances and meanings intended. For example, whether spoken, sung, female, or male, a 'low' voice often simply meant one that was quiet, weak or submissive (rather than indicating pitch), as in Thomas Ravenscroft's (c.1588-1635) prefatory singing directions in The Whole Booke Of Psalmes (1633), which contrasts 'low' with 'loude'. ${ }^{148}$ Likewise, a 'high' voice frequently indicated excitement, emotion, or a loud volume rather than exclusively describing pitch per se; this is exemplified by Stephen Batman's (d. 1584) observation that the 'perfect voyce' in music should (amongst other things) be 'high to bee well heard'. ${ }^{149}$ This conflation of 'high' and 'loud' versus 'low' and 'quiet' is frequently seen in contemporary descriptions of (loud) 'treble' versus (soft) 'tenor' and 'bass' voices, ${ }^{150}$ and it can be traced back through several previous centuries in literary, musical, and theoretical sources from across Europe. ${ }^{151}$ Thus, it seems that 'high' and 'low' often relate only partially or indirectly to pitch except

\footnotetext{
${ }^{143}$ See John M. Wasson, ed., Records of Early English Drama: Devon (Toronto: University of Toronto Press, 1986), $288-90$.

${ }^{144}$ T. G. (Thomas Gainsford?), The Rich Cabinet (London: John Beale, 1616), p. $71^{\mathrm{r}}$. An oft-recurring phrase used to describe eunuchs is 'a man and yet no man', as in John Case (attrib.), The Praise of Mvsicke (Oxford: Joseph Barnes, 1586 ), 82.

${ }^{145}$ Florio, A Worlde of Wordes, 363 (entry for 'Semiuiro'); Thomas de Fougasses, The Generall Historie of the Magnificent State of Venice (London: George Eld and William Stansby, 1612), i, 9; Crooke, Mikrokosmographia, iv, 242.

${ }^{146}$ Ambroise Paré, The Workes of that famous Chirurgion Ambrose Parey, trans. Thomas Johnson (London: Thomas Cotes, 1634), 975. See also William Prynne's famous Histrio-mastix. The Players Scovrge (London: Edward Allde and William Jones, 1633), especially Act 5, scene vi, pp. 178-216.

${ }^{147}$ Ortensio Landi, Delectable demaundes, and pleasaunt Questions, with their seuerall Aunswers, trans. William Painter (London: John Cawood, 1566), ii, p.27 ${ }^{\mathrm{r}}$.

${ }^{148}$ Thomas Ravenscroft, preface 'To All That Have Skill, or Will vnto Sacred Musicke', The Whole Booke Of Psalmes (London: Thomas Harper, 1633), unpaginated. Other representative examples include Thomas Hill, The Contemplation of Mankinde (London: Henry Denham, 1571), p. 134 ${ }^{\mathrm{r}}$ : 'The voyce decerned small and lowe, doth indicate such a creature to be fearefull, and enuious. By this low voyce, is here ment (sayth the Phisiognomer) the small and faint voyce: and not the bigge, in any maner'; and Gualtherus Bruele, Praxis Medicine, Or, The Physicians Practice (London; John Norton, 1632), 136: 'Svch men are sayd to be dull of hearing, who cannot heare a low voyce, and scarce vnderstand loud voyces'.

${ }^{149}$ Stephen Batman, Batman vppon Bartholome (London: Thomas East, 1582), xix, ch. 134 ('De musica'), sig. Cccc.iiv . Other representative examples include Hill, The Contemplation of Mankinde, p. 133 ${ }^{\mathrm{v}}$ : 'a person which hath a grosse, high, and sounding voyce: is reported to be eloquent, bold, fierce, and valiant in armes, or a warriour'; and Jean de Hainault, The Estate of the Church, With the discourse of times, from the Apostles vntill this present, trans. Simon Patrick (London: Thomas Creede, 1602), 480, where a guard on the town gates of Arras 'vsed customably vpon the wall to sing with an high voyce' to 'aduertise the enemies when they should approach'.

${ }^{150}$ For representative examples, see Philemon Holland, The Philosophie, commonlie called, The Morals (London: Arnold Hatfield, 1603), 69 (the 'Meane' is between the 'height and loudnesse' of the treble and the 'lownesse or basenesse' of the bass); and Josuah Sylvester, Du Bartas His Deuine Weekes and Workes Translated (London: Humphrey Lownes, 1611 ), 92 ('your loud Trebbles help my lowly Bassus'). The word 'shrill', meaning 'loud' or 'clear', also occurs both generally and in relation to treble voices, and could be positive or negative; contrast Thomas Hoby, The Covrtyer of Covnt Baldessar Castilio (London: William Seres, 1561), sig.Fiiii' (amongst other things, a 'good voyce' is 'shrill') with Thomas Middleton, The Famelie Of Love (London: Richard Bradock, 1608), Act 5, 'scaena vltima', sig.I2 ('your wife makes you deafe with the shrill treble of her tong').

${ }^{151}$ A pertinent example can be found in descriptions of the so-called 'alta capella' or wind band of the late Middle Ages by (amongst others) Konrad of Megenberg (1309-74) and Johannes Tinctoris (c.1435-1511), where 'alta' had both connotations 'loud' and 'high' whereas 'bas' instruments were considered to be 'soft' and 'low'; see Herbert W. Myers, 'Reeds and Brass',
} 
where musical 'notes' or 'sounds' are explicitly described, but even here, the terms must be understood in a relative sense and therefore fail to provide clear evidence for falsetto singing. ${ }^{152}$ Other words used to describe voices include 'small' and 'litle' - generally for women, children and eunuchs - or 'great' and 'deepe' - generally for men. This distinction occurs frequently and was linked to understanding of biological differences between ages and genders; ${ }^{153}$ indeed, 'a great voyce in a woman' was considered to be 'an euill sygne', whereas men who had a 'small voyce' were thought to be weak. ${ }^{154}$

Occasionally, specific musical terminology is also used. Several texts mention a man's 'treble voyce', which could initially seem to indicate falsetto singing, although it should be noted that none of these references occur in relation to lute accompaniment. ${ }^{155}$ A number of these describe the typical 'balladmonger' or 'common Fidler' who, amongst other things, 'can Match his Treble to the Uioll'. ${ }^{156}$ However, these are illiterate singer-sellers who are usually portrayed in unambiguously unflattering terms - for example, as so impoverished that 'his totall meanes amounts but to fiue markes, which he hath miseraby [sic] beene scraping all his life-time' and whose best source of income is 'Drunkards, and such as are lasciuiously inclin'd' - a somewhat different context, audience, and performer from those of the printed lute song collections. ${ }^{157}$ Furthermore, the collective references that describe a man's 'treble' voice are not only tiny in number but they also seem to be predominantly metaphorical (meaning 'at the top of his range') rather than indicating literal pitches in a G2-clef. ${ }^{158}$ The same is true of references to a man singing or exclaiming 'a note aboue Ela' ('Ela' was the highest note in the Guidonian system, i.e. $\mathrm{e}^{\prime \prime}$ ), where a literal reading is undermined by the existence of similar wording in relation to women's voices. ${ }^{159}$

A Performer's Guide to Medieval Music, Ross W. Duffin, ed. (Bloomington: Indiana University Press, 2000), 384-98. The phrase 'alta voce' also occurs frequently in Medieval texts and replicates this 'loud'-'high' conflation; for a representative example, see Richard Rastall, Minstrels Playing: Music in Early English Religious Drama II (Cambridge: D. S. Brewer, 2001), $247-8$.

${ }^{152}$ For example, see Robert Robinson, The Art of Pronuntiation (London: Nicholas Okes, 1617), particularly sig. B11 ${ }^{\mathrm{r}}-\mathrm{B} 12^{\mathrm{r}}$, where the 'sounds' of 'mans voice' are 'obserued of Musitians, by placing higher or lower (as the case doth require) of sundry formed cliffes [...] the Faut, C: solfavt, and G solrevt cliffes, that are chiefly in vse, vpon certaine parralell lynes drawne one aboue another to expres the height or depth of their sounds'.

${ }^{153}$ For a pertinent example, see Bacon, Sylva Sylvarvm, Century ii, 52 and Century ix, 226. On eunuchs and 'small' voices, see Juan Huarte, Examen de ingenios, trans. Richard Carew (London: Adam Islip, 1594), 279-80.

${ }^{154}$ See Robert Copland (attrib.), The Shepardes Kalender (London: Thomas East, ?1570), sig. Lvii ${ }^{\mathrm{r}}$; and Raphael Holinshed, The Firste volume of the Chronicles of England, Scotlande, and Irelande (London: John Hunne, 1577), ii, 36, on the physical characteristics of Richard de Clare, Second Earl of Pembroke (1130-76).

${ }^{155}$ A reference in Marcos Martínez, The Eighth Booke of the Myrror of Knighthood. Being the third of the third Part, trans. L. A. (London: Thomas Creede, 1599), sig. $\mathrm{Kk}^{\mathrm{v}}$, where Agesilao sings to a lute and 'did [...] runne vpon the treble with such heauenly melodie', could initially seem to provide an exception, but 'treble' actually refers to the lute's top string here. The verb 'runne' occurs elsewhere in relation to (fast) lute playing, as in Cyril Tourneur, The Atheist's Tragedie (London: Thomas Snodham, 1611), Act 4, scene i, sig. $\mathrm{H} 2^{\mathrm{r}}$.

${ }^{156}$ The quote is taken from Henry Fitzgeffrey, 'Notes from Black-Fryers', Satyres: And Satyricall Epigram's: With Certaine Obseruations at Black-Fryers? (London: Edward Allde, 1617), sig. F6 ${ }^{\mathrm{r}}-\mathrm{F} 6{ }^{\mathrm{v}}$, at sig. F6 ${ }^{\mathrm{v}}$. See also Henry Chettle, Kind-Harts Dreame (London: J. Wolfe and J. Danter, ?1593), C2 ${ }^{\mathrm{r}}$ (see also sig. B2 ${ }^{\mathrm{v}}$ ); Henry Hutton, Follie's Anatomie (London: Nicholas Okes, 1619), sig. $\mathrm{B} 3^{\mathrm{r}}-\mathrm{B} 4^{\mathrm{r}}$, at $\mathrm{B} 4^{\mathrm{r}}$; and Richard Brathwaite, Whimzies: Or, A Nevv Cast Of Characters (London: Felix Kingston, 1631 ), 13.

${ }^{157}$ Henry Parrot, Cvres For The Itch (London: J. Haviland and M. Flesher, 1626), sig. A $8^{\mathrm{v}}-\mathrm{B}^{\mathrm{r}}$, at sig. $\mathrm{B}^{\mathrm{r}}$. Various English ballad collections survive from the period, both printed and manuscript - significantly, without music; see Verse Miscellanies Online, www.versemiscellaniesonline.bodleian.ox.ac.uk. On the different context of ballad singers, see Marsh, Music and Society in Early Modern England, 239-42.

${ }^{158}$ For representative examples, see Marcos Martínez, The sixth Booke of the Myrrour of Knighthood, trans. Robert Parry (attrib.) (London: Edward Allde, 1598), part 3, i, sig. I' (lovesick Torismundo exclaims 'My wofull selfe will sing or cry the treble' whilst the 'still streame' provides the 'meane' and the 'Wilde Forrest beasts' the 'base'); and Girolamo Fracastoro, The Maidens Blush, trans. Josuah Sylvester (London: Humphrey Lownes, 1620), sig. $\mathrm{B}^{\mathrm{r}}$ (Joseph calls to his fellow shepherds 'with his Treble throat, / So loud and shrill'). Some references to a 'treble voic'd' man simply mean 'three-voiced', particularly in relation to hell's porter (alluding to Cerberus, the three-headed hound of Hades), as in John Taylor, The Eighth VVonder Of The VVorld (London: Nicholas Okes, 1613), sig. B2 ${ }^{\mathrm{r}}$.

${ }^{159}$ Examples of men sounding 'ela' are: John Lyly, Euphues and his England (London: Thomas East, 1580), sig. Aiir'; and Gervase Markham, A Health to the Gentlemanly profession of Seruingmen (London: W. White, 1598), sig. $\mathrm{G}^{\mathrm{v}}$. For similar descriptions of women's voices, see Robert Greene, Greenes Neuer too late (London: Thomas Orwin, 1590), 44; and Thomas Dekker, Blvrt Master-constable. Or The Spaniards Night-walke (London: Edward Allde, 1602), sig. E4 ${ }^{\mathrm{r}}$. 
Discussions of the voice in contemporary anatomical and rhetorical works and almanacs provide further context here. In his Mikrokosmographia (1615), for example, the royal physician Helkiah Crooke (1576-1635) noted that a man might 'vary' his spoken voice 'high, low, or in a middle key, or as we say Treble, Base or Tenor', ${ }^{160}$ whilst others like Robert Robinson (fl. 1617) and Richard Mulcaster (?15301611) used more generic terminology to describe man's spoken range (from 'shrill and lowd' to 'base and deep'). ${ }^{161}$ Several writers noted that the 'meane' was the optimal spoken voice for a man, since a 'meane voyce in sounde and in greatnes, declareth the man to bee wyse, circumspecte, iuste, and trew' ${ }^{162}$ Clearly, in such passages, 'meane' does not indicate the musical pitch associated with the 'meane' sung voice of a boy; rather, it relates here to a midrange adult male voice, and such usage was not confined exclusively to 'scientific' texts. ${ }^{163}$ These writings about a man's spoken voice in turn contextualize descriptions of a man's singing voice that imply a similarly large range, like that of Philemon Holland (1552-1637), who noted that 'Musicians are woont to guide and rule the voice gently by little and little up and downe, betweene base to treble, according to everie note as they would themselves, teaching their scholars thereby to have a tunable voice'. ${ }^{164}$ Furthermore, the general preference for a 'meane' (i.e. midrange) adult male spoken voice convincingly explains why some texts that discuss man's singing actually seem to conflate 'a Meane, or Tenor. ${ }^{165}$ In any case, the rarity of references to a man's 'treble' voice can be set alongside equally unusual descriptions of female voices that use words such as 'alt', 'tenour', and even 'bace'. ${ }^{166}$

Finally, the verb 'faine' or 'feign' (and its related adjectives) has sometimes been assumed to indicate the 'falsetto' voice in scholarship to date. ${ }^{167}$ The musical use of this word seems to have been linked closely to its more typical nonmusical definitions: 'to counterfeit', 'to inuent a lie', 'to falsifie', etc., much like the modern 'feign'. For example, the lexicographers Richard Huloet (fl. 1552) and Thomas Cooper (? 1517-94) translate the Latin verb 'incino, incinere' respectively as 'Singe a tryple, properly to fayne a small breast' and 'To sing: to feyne a small voyce: to sowne pleasantlye and with melodie', thus equating singing a treble part with imitating or pretending to have a high voice. ${ }^{168}$

\footnotetext{
${ }^{160}$ Crooke, Mikrokosmographia, viii, 644 (sic. = 640); see also x, 766 and xii, 911.

${ }^{161}$ Robinson, The Art of Pronuntiation, sig. A12v ; and Richard Mulcaster, Positions VVherin Those Primitive Circvmstances Be Examined, Which Are Necessarie For The Training vp of Children (London: Thomas Vautrollier, 1581), 55-8.

${ }^{162}$ Richard Roussat, The Most excellent, profitable, and pleasant booke of the famous doctour and expert Astrologien Arcandain, trans. William Ward (London: James Rowbotham, ?1562), sig. Riiij ${ }^{\mathrm{v}}$. See also Abraham Fraunce, The Arcadian Rhetorike (London: Thomas Orwin, 1588), ii, sig. H6 $6^{\mathrm{v}}$; and Hill, The Contemplation of Mankinde, pp. $7^{\mathrm{v}}-8^{\mathrm{r}}$ and p. $134^{\mathrm{v}}$.

${ }^{163}$ For example, see Nicholas Breton, I Pray you be not Angry, for I will make you merry (London; Augustine Mathewes, 1624), sig. $3^{\mathrm{v}}-\mathrm{B} 4^{\mathrm{r}}$, where Fabiano describes a 'young man' whose voice was 'neyther Treble nor Base, but a good meane' - clearly a youth of sexual maturity, since he subsequently 'playes false with my seruant maide' and 'steales away my eldest daughter'.

${ }^{164}$ Holland, The Philosophie, 122. For similar descriptions, see Pierre de La Primaudaye, The Second Part Of The French Academie, trans. Thomas Bowes (London: G. Bishop, Ralph Newbery, R. Barker, 1594), 95; and Brathwaite's description of a 'Ballad-monger' in Whimzies, 13.

${ }^{165}$ For example, see Bacon, Sylva Sylvarvm, Century ii, p. 51 ('a Meane, or Tenor, is the sweetest Part'); and de La Primaudaye, The Second Part of The French Academie, p. 95 (a man may 'open and shut' his larynx 'in middle sort either more or lesse to make the tenor or the meane'). See also Thomas Churchyard, The Firste parte of Churchyardes Chippes, contayning twelue seuerall Labours (London: Thomas Marshe, 1575), 119 (the 'Marchants keep a mean vnmixt, / with any iarryng part: / And bryng boeth Treble and the Baess, in order still by art').

${ }^{166}$ Arthur Golding, trans., The. XV. Bookes of P. Ouidius Naso, entytuled Metamorphosis (London: William Seres, 1567), xii, p. $151^{\mathrm{r}}$ (Ceny asks to be 'no more a woman', which she says 'in bacer tune [...] and her voyce / Did seeme a mannes voyce as it was in déede'); Kennedy, The Historie Of Calanthrop And Lvcilla, sig. B3 ${ }^{\mathrm{r}}$, on the two 'Furies' Megaera and Alecto (the Goddesses of Vengeance): 'For whilst their Lutes, a Base or Tenour sound, / Their voyce in Alts sweet musicke doe abound'; Purchas, Pvrchas his Pilgrimes. In Five Bookes, part 4, vii, ch. 1, p. 1293 (on the 'Indians of Brasil': 'They keepe among themselues differencies of voices in their Consort: and ordinarily the women doe sing the Treble, Counter, and Tenours').

${ }^{167}$ Unlike today, where 'faining' and 'feigning' have different definitions, the spellings and meanings are used interchangeably in contemporary sources. See James Stark, Bel Canto: A History of Vocal Pedagogy (Toronto: University of Toronto Press, 1999/2003), 35-6, 58-67. See also Christopher Page, The Guitar in Tudor England: A Social and Musical History (Cambridge: Cambridge University Press, 2015), 132, no. 16; and Parrott, 'Falsetto Beliefs', 106, no. 113. 'Faine' also occurs as an adverb, meaning 'willingly' or 'happily', as in Campion, The Third and Fovrth Booke of Ayres, iv, song 24 ('Faine would I wed a faire yong man').

${ }^{168}$ Richard Huloet, rev. John Higgins, Hvloets Dictionarie, newelye corrected, amended, Set In Order And Enlarged (London: Thomas Marsh, 1572), sig. Qqiir, 'S. ante. I.'; Thomas Cooper, Thesavrvs Lingva Romana \& Britannicee (London: Henry
} 
A famous musical use of 'faine' that might perhaps indicate falsetto singing (possibly for a specific effect) occurs in Thomas Campion's description of the 1613 entertainment cited above, where 'the Robin-hood-men faine two Trebles' in a five-voice song. ${ }^{169}$ Yet the idea that this word generally meant falsetto singing at this time is questionable. John Florio, for example, does not link 'faine' to 'falsetto' (or 'false treble'), even though he uses this word in another musical context, in his entry for 'Croma': ' ... pleasant and delightsome musike with descant, faining or quauering', a description which closely resembles Philemon Holland's definition of 'Chromaticke Musicke'. ${ }^{170}$ Other sources also suggest a link between 'faine' and ornamentation, such as Nicholas Breton's The Court and Country (1618), which twice contrasts 'faine' with 'sing plaine'. ${ }^{171}$

The word 'faine' elsewhere seems to relate to a soft volume in musical contexts. A pertinent example occurs in Cooper's translation of a Latin quotation of Marcus Fabius Quintilianus (c.35-100 AD) ('elisa voce canere, vel loqui'): 'To feygne in singing: to speake in a small feygning voyce: also to speake or singe as one coulde heardely vtter his voyce'. ${ }^{172}$ Other musical references appear to conflate 'faine' with 'faint' or 'faintly', ${ }^{173}$ recalling in turn the frequently seen link between 'tenor' or 'bass' singing and a 'soft' delivery, as in contemporary translations of the Latin 'succino, succinere' (rendered variously as 'to fain in singing' and 'To make a soft noyse: to sing a base or tenor', etc.). ${ }^{174}$ Indeed, in his 1593 translation of a French description of a nightingale's singing, in which the bird traverses different polyphonic voice parts (from treble to bass), John Eliot renders the verb 'contrefaire' in four ways - 'sings', 'counterfeiteth', 'quauereth' and 'faineth' - significantly, pairing 'faineth' with 'the base'. ${ }^{175}$

Denham, 1578), sig. Qqq2v, 'INC': 'incino'. Modern Latin dictionaries translate this word more generally (e.g. to cause to sound, to strike up, to sing, etc.), which may suggest a change in linguistic expression rather than a loss of precise meaning.

${ }^{169}$ Campion, A Relation Of The Late Royall Entertainment, sig. A4 ${ }^{\mathrm{r}}$. Parrott, 'Falsetto Beliefs', 106, no. 112, offers several possible interpretations of this sentence (some convincing, others - like miming to someone else's treble singing - less so).

${ }^{170}$ Florio, A Worlde of Wordes, 92. See Holland, The Philosophie, sig. Zzzzz2v', 'Chromaticke Musicke': 'soft, delicate and effeminate, ful of descant, fained voices and quavering, as some are of opinion'. In modern Italian, 'croma' means a quaver (eighth note), which may suggest fast note values here (hence 'quauering').

${ }^{171}$ Nicholas Breton, The Court and Country (London: George Eld, 1618), sig. A4 ${ }^{\mathrm{v}}$ and sig. D4 $4^{\mathrm{r}}$. Certain foreign dictionaries replicate this trend, like Mathias Sasbout, Dictionaire Francoys-Flameng Tres Ample Et Copievx (Anvers: Jean Waesberghe, 1579), 'FA', sig. Aa2 ${ }^{\mathrm{v}}$, where 'Faulset en chanterie' is translated as 'De diminueringhe oft de schetteringhe int singhen' - a description which appears almost verbatim in Jean Waesberghe, Dictionaire Francois-Flamen Tres-Ample Et Copievx (Rotterdam: Jean Waesberghe, 1599), sig. X2 ${ }^{\mathrm{v}}$, this time as a definition for 'Fredon' (in modern French, 'fredonner' means 'hum' or 'croon'). 'Schetteringhe' is translated in its musical sense by Henry Hexham, Het Groot Woorden-Boeck (Rotterdam: Arnout Leers, 1658), 'SCH', sig. Ee4 $4^{\mathrm{v}}$ as 'a Quavering in Musick'.

${ }^{172}$ Cooper, Thesavrvs Lingve, sig. Tttttt3 ${ }^{\mathrm{r}}$, 'VOX'. Interestingly, this quote also appears in several Continental dictionaries; for example, see anon., Lexicon Trilingve, Ex Thesavro Roberti Stephani (Strasbourg: Theodosius Rihelius, 1586), sig. SSss ${ }^{\mathrm{r}}$ ('VOX'), which translates this sentence as 'falsch singen oder reden', whilst Jean Nicot, Thresor De La Langve Francoyse (Paris: David Douceur, 1606), 281 ('FA') renders it 'Chanter ou parler en faulset'.

${ }^{173}$ For example, see Richard Capel, Tentations. Their Nature, Danger, Cure (London: R. Badger, 1633), 152 ('men faint and sing many a heavy song'). This confusion may stem from French, as in John Cowell, The Interpreter: Or Booke Containing the Signification of VVords (Cambridge: John Legate, 1607), sig. Dd4v, 'FA', entry for 'Faint and false action': '... For (faint) in the French tongue signifieth as much as (fained) in English'.

${ }^{174}$ John Stanbridge, rev. Thomas Paynell, Vocabula Magistri, Sta[n]brigij (London: John Day, ?1560), sig. E4" ('to singe the base'); Peter Levins, Manipvlvs Vocabvlorvm: A Dictionarie of English and Latine Words (London: Henry Bynneman, 1570), sig. Qiii ', 'Ay ante N' ('to fain in singing'); and Cooper, Thesavrvs Lingve, sig. Ffffff2 ${ }^{\mathrm{r}}$, 'SVC' ('... To make a soft noyse: to sing a base or tenor'). Huloet, Hvloets Dictionarie, 'T. ante E.', sig. Vvii ${ }^{\mathrm{r}}$ translates 'Tenor' as 'he $\mathrm{y}^{\mathrm{t}}$ singeth a tenor. Succentor, ris. $\mathrm{m}$. ge.' (linking to the verb succino), whilst Dupleix, The Resoluer, 291, notes that the 'base' is 'the voice the most grosse, and which singeth the most softly'. A tiny handful of texts ascribe characteristics like 'bellowing' and 'roare' to tenor and bass voices, although these generally do so for a specific 'manly', warlike, or bucolic effect; see Brian Vickers, ed., Oxford World's Classics: Francis Bacon: The Major Works (Oxford: Oxford University Press, 1996/2002), 416; and Jonson, 'The Second Masqve', The Characters of Two royall Masques (1608), sig. $\mathrm{E}^{\mathrm{r}}$.

${ }^{175}$ John Eliot, Ortho-Epia Gallica. Eliots Frvits for the French (London: Richard Field, 1593), 150-1. The nightingale is described in several other sources in a similar fashion, singing all the parts in polyphonic music; for representative examples, see Pierre Boaistuau, trans. John Alday, Theatrum mundi, The Theatre or rule of the world (London: H. D., ?1566), sig. cvir ${ }^{\mathrm{r}}$; and Sylvester, Du Bartas, 132. 
Other examples of 'faine' in musical contexts seem to indicate a manner of delivery, such as the use of cunning or pretence, as in A Midsommer nights dreame (1600) by William Shakespeare (1564-1616), where Egeus complains that Duke Lysander has stolen his daughter's heart after having (amongst other things) 'by moone-light, at her windowe sung, / With faining voice, verses of faining loue'. ${ }^{176}$ This may link to nonmusical definitions such as Abraham Fraunce's (1558-92) explanation of the literary device prosopopoeia - the 'fayning of any person, when in our speach we represent the person of anie, and make it speake as though he were there present' ${ }^{177}$ - in turn perhaps explaining why some sources appear to distinguish 'faine' from 'sing. ${ }^{178}$

Whatever 'faine' therefore means in any given example from a musical context, it clearly represents problematic evidence for the falsetto voice in the lute song repertory. Moreover, it would appear that it was not always used exclusively to describe male voices, since at least one contemporary literary text The second Tome of the Palace of Pleasure (1567) by William Painter (?1540-94) - describes 'three Amorous Gentlewomen' who each had 'a heauenlie voice to faine and sing. ${ }^{179}$ Similarly, almost none of the numerous contemporary English literary references that describe a man singing to a lute use the word 'faine', and those that do seem to fall outside the immediate period in which the lute song collections were printed (1597-1622; see Appendix 2). Instead, most sources simply use 'sing' or sometimes 'warble', or more rarely words like 'accord', 'sought out', and 'sound'. ${ }^{180}$ The tiny handful of references which mention a man 'faining' to a lute are also primarily translations of foreign texts from countries where falsetto singing may have been more known. ${ }^{181}$

In view of all of the above, it therefore seems likely that lute songs were not intended for a man singing in his falsetto voice. Indeed, this manner of singing can only be justified in the lute song repertory by assuming that words like 'sing' and 'warble' function as generic umbrella terms for any vocal technique or style of performance imaginable. Contemporaries also seem to have favoured a 'naturall voyce', ${ }^{182}$ and

\footnotetext{
${ }^{176}$ See William Shakespeare, A Midsommer Nights Dreame (London: Richard Bradock, 1600), Act 1, sig. A2 $2^{\mathrm{v}}$. Other uses of 'feigned voyce' imply pretence or imitation like Abraham Fleming, A Panoplie of Epistles (London: Henry Middleton, 1576), 402 (he 'had spoken his words with a feigning voice like a Gyant').

${ }^{177}$ Fraunce, The Arcadian Rhetorike, sig. G2 ${ }^{\mathrm{r}}$. See also John Brinsley, Cato Translated Grammatically (London: Humphrey Lownes, 1612), iii, 21: 'For the Poets doe sing things to be maruelled at, but not to be beleeued'.

${ }^{178}$ For example, see Barnabe Rich, Rich his Farewell to Militarie profession (London: George Eld, 1606), sig. A2 ', where the 'commendable qualities' he needs to impress 'Gentlewomen' include 'sight in Song' which he calls 'faining some prety Ditties', but he notes: 'my mouth is so vnpleasant, either to sing, or to faine, as would rather breed your lothing, then your liking'.

${ }^{179}$ William Painter, The second Tome of the Palace of Pleasure (London: Henry Bynneman, 1567), novel 14, p. 89v . Painter later describes (novel 24, p. $205^{\mathrm{v}}$ [sig. FFf. $\mathrm{i}^{\mathrm{v}}$ ]) how, in the city, love songs were 'more common in eche Citizens mouthe, than the Stanze or Sonnets of Petrarch, played and fained vpon the Gittorne, Lute or Harpe of these of Noble house' ('citizens' presumably includes women). In Robert Greene, rev. John Dickenson, Greene In Conceipt (London: Richard Bradock, 1598), 53, Valeria 'tooke hir Lute, and therto warbled with a fainting voice', which may be a conflation with 'faining'. See also Thomas Nash, Pierce Penilesse His Svpplication to the Diuell (London: Abell Jeffes, 1592), sig. B3 ${ }^{\mathrm{v}}$ : 'the puling accent of her voyce is like a famed treble, or ones voyce that interprets to the puppets', where 'famed' may be a misprint for 'fained'.

${ }^{180}$ For representative examples, see: Hoby, The Covrtyer of Covnt Baldessar Castilio, Book 2, sig. m.iiiir (sing); Robert Greene, Perimedes The Blacke-Smith (London: John Wolfe, 1588), sig. $\mathrm{G}^{\mathrm{v}}$ (warble); Thomas Watson, The Hekatompathia Or Passionate Centurie of Loue (London: John Wolfe, 1582), Sonnet XII, sig. B2 ${ }^{\mathrm{v}}$ (accord); Saker, Narbonus, ii, 26 (sought out); George Turberville, Epitaphes, Epigrams, Songs and Sonets (London: Henry Denham, 1567), p. 143 ${ }^{\mathrm{v}}$ (sound); and Thomas Lodge, An Alarum against Vsurers (London: Thomas East, 1584), p. $22^{\mathrm{r}}$ (recorded).

${ }^{181}$ Desiderius Erasmus, The Arte of Rhetorique, trans. Thomas Wilson (London: Richard Grafton, 1553), ii, 72; and Painter, The second Tome of the Palace of Pleasure, novel 23 (The Duchesse of Malfi), pp. $170^{\mathrm{v}}-171^{\mathrm{r}}$ and novel 29 (Dom Diego and Gineura), p. $320^{\mathrm{r}}$.

${ }^{182}$ See Robinson, “'A perfect-full harmonie”, 200, no. 20. See also Richard Greenham, rev. Henry Holland, The Workes Of The Reverend And Faithfvll Servant Af Iesvs Christ M. Richard Greenham (London: Thomas Snodham and Thomas Creede, 1612), 330, which criticizes 'hypocrites' who 'haue not the sweete and naturall voyce, which commeth from a well affected and right ordered minde'; Allison, The Psalmes Of Dauid in Meter, who says the 'singing part' should be 'either Tenor or Treble [...] according to the nature of the voyce'; and Robinson, The Art of Pronuntiation, whose title page boasts that it is 'very necessary $[\ldots]$ to know the naturall structure of the voice'. Other texts express negative opinions on singers going beyond a natural range,
} 
even some modern exponents of the falsetto voice do not consider it to be 'natural'. ${ }^{183}$ Furthermore, sixteenth- and seventeenth-century writers clearly distinguished the sound of a 'mannes voyce' from a 'boyes voyce', ${ }^{184}$ and unambiguous evidence for English men singing in a soprano range to lute accompaniment seems to be similarly absent.

\section{Conclusions}

Having analysed the printed lute song collections alongside evidence both for the lute and also singing in late Tudor and early Stuart England, the following conclusions may be drawn. Firstly, it is evident that all of the lute song collections were printed in a format which was supposed to facilitate instant performance, primarily with a mean lute in $\mathrm{g}^{\prime}$ or bass viol (or both together) and, except in rare cases where the voice has to fit the lute's differently pitched tablature, without the need for any transposition. Secondly, this repertory was intended for singers of all ages and both genders, with women and children singing the song melodies in the written treble register and men singing them in the octave below (excluding the occasional songs that use low clefs like C4 and F4-clefs, which were clearly intended primarily for a male voice at pitch). It also seems very questionable that this performance solution might have changed simply depending on the amateur or professional background or context of the singer. ${ }^{185}$ Perhaps more importantly, these specific conclusions about the lute song provide further support for the recent research which has challenged the use of falsetto singing in England more generally at this time (particularly within a sacred context). In short, perhaps the lost soundworld of 'the sweetest Lute, and best composed song' in England c.1595-1625 is finally emerging with more clarity via a better understanding of the likely voices which would 'to the lute full many a dittie sing'. ${ }^{186}$

Acknowledgements. A version of this paper was presented at the Medieval and Renaissance Music Conference in Basel, July 2019. I am indebted to John Bryan, Katherine Butler, Christopher Page, John Potter, Anthony Rooley, Richard Wistreich and Crawford Young for their advice on early versions of this article. I am also grateful to Michael Fleming for providing several references in Appendix 1a, and to Christopher Goodwin, Elisabeth Leedham-Green, John Milsom, Robert Thompson and David van Edwards for their assistance with various other queries.

like Thomas Adams, A Divine Herball Together with a Forrest of Thornes (London: George Purslowe, 1616), 85 ('forc'd squeaking trebble').

${ }^{183}$ In a 2004 interview for the Independent, the countertenor James Bowman apparently 'admitted that the countertenor voice could be described as fake: "It's an acquired technique. Nobody speaks in that register."'; see Michael Church, 'The highs and the lows', Independent (3 May 2004), https://www.independent.co.uk/arts-entertainment/music/features/the-highs-andthe-lows-58710.html. See also James C. McKinney, The Diagnosis \& Correction of Vocal Faults: A Manual for Teachers of Singing \& for Choir Directors (Illinois: Genevox Music Group, 1994), 96-7.

${ }^{184}$ Thomas Lupton, A Moral And Pitiefvl Comedie, Intituled, All for Money (London: Roger Warde and Richard Mundee, 1578), sig. $\mathrm{Di}^{\mathrm{r}}$ ('Shall I in my mannes voyce or in my boyes voyce it declare?'); and William Shakespeare, The most excellent Historie of the Merchant of Venice (London: James Roberts, 1600), Act 3, scene iv, sig. Gv ('speake betweene the change of man and boy, vvith a reede voyce'). See also Francis Meres, Wits Common Wealth The Second Part (London: William Stansby, 1634), 423 (an 'old singer [...] leaueth the shriller parts of singing vnto youth, who are more sit [=fit] for them').

${ }^{185}$ For example, see Campion, The Description of a Maske [...] At the Mariage of the Right Honourable the Earle of Somerset, sig. $\mathrm{C}^{\mathrm{v}}$, sig. $\mathrm{C}^{\mathrm{v}}$ and sig. $\mathrm{D} 2^{\mathrm{v}}$, where professional musicians like John Coprario and Nicholas Lanier are named alongside several noblemen who participated as 'Maskers'. Amateur musicians were thus surely influenced by trends in professional musicmaking.

${ }^{186}$ Quotations taken respectively from George Whetstone, The English Myrror (London: John Windet, 1586), 163; and Appendix 2 doc. 14.

Cite this article: Robinson, R. 2021. 'With sound of lute and pleasing words': The Lute Song and Voice Types in Late Sixteenth- and Early Seventeenth-Century England. Royal Musical Association Research Chronicle, 52, 1-62. https://doi.org/ $10.1017 /$ rrc.2020.3 


\section{APPENDIX 1a}

References to Lutes in Noble and Gentry Inventories, Wills, \& Other Documents (1585-1635).

\begin{tabular}{|c|c|c|c|c|}
\hline Location & Year & $\begin{array}{l}\text { Repository and Shelf } \\
\text { mark }\end{array}$ & Record details & Lute details \\
\hline \multirow[t]{4}{*}{ Bristol } & 1598 & $\begin{array}{l}\text { BRO: will William } \\
\text { JACY } 1598\end{array}$ & $\begin{array}{l}\text { Will of William Jacy, parson } \\
\text { of St Michael's Church, } \\
\text { Bristol }\end{array}$ & 'my lute' \\
\hline & 1613 & $\begin{array}{l}\text { BRO: inventory } \\
1613 / 37\end{array}$ & $\begin{array}{l}\text { Inventory of George Lane, } \\
\text { Bristol }\end{array}$ & 'a lute with his Case' \\
\hline & 1613 & $\begin{array}{l}\text { BRO: inventory } \\
1613 / 51\end{array}$ & $\begin{array}{l}\text { Inventory of Thomas } \\
\text { Saunders, Pinker, Bristol }\end{array}$ & 'ij lutes’ \\
\hline & 1634 & $\begin{array}{l}\text { BRO: will Thomas } \\
\text { PRINCE } 1634\end{array}$ & $\begin{array}{l}\text { Will of Thomas Prince, lay } \\
\text { petty canon at Bristol } \\
\text { Cathedral }\end{array}$ & 'my Twoe Lutes' \\
\hline \multirow[t]{7}{*}{ Cambridge } & 1586 & CUL: VCCt.Invs 4 & $\begin{array}{l}\text { Nicholas Abythell, Fellow of } \\
\text { Trinity College }\end{array}$ & 'Two old lutes' \\
\hline & 1589 & CUL: VCCt.Prob.M.1 & $\begin{array}{l}\text { Will of Andrew Perne, } \\
\text { Master at Peterhouse } \\
\text { and Dean of Ely } \\
\text { Cathedral }\end{array}$ & 'a lute with a case' \\
\hline & 1591 & CUL: VCCt.Invs 5 & $\begin{array}{l}\text { Will of Thomas Lorkin, } \\
\text { Regius Prof of Physick }\end{array}$ & 'a lute with a case' \\
\hline & 1598 & CUL: VCCt.Invs 6 & $\begin{array}{l}\text { Inventory of John Bettis, } \\
\text { Fellow of Trinity College }\end{array}$ & 'a lute and lutecase' \\
\hline & 1608 & CUL: VCCt.Invs 7 & $\begin{array}{l}\text { Will of Godwin Walsall, } \\
\text { Fellow of Corpus Christi } \\
\text { College (Hebrew } \\
\text { Lecturer) }\end{array}$ & 'a lute \& a lute case' \\
\hline & 1631 & CUL: VCCt.Invs 11 & $\begin{array}{l}\text { Inventory of Thomas } \\
\text { Jordan, Regius Prof of } \\
\text { Physick }\end{array}$ & 'one lute' \\
\hline & 1635 & $\begin{array}{l}\text { CUL: VCCt.Invs } \\
\text { bundle } 2\end{array}$ & $\begin{array}{l}\text { Inventory of Stephen Mace, } \\
\text { lay clerk }\end{array}$ & '4 lutes' \\
\hline \multirow[t]{6}{*}{ Chester } & 1587 & CCALS: EDA $2 / 2$ & $\begin{array}{l}\text { Will of John Coppock, } \\
\text { Gentleman, Chester }\end{array}$ & 'my lute and Lutinge booke' \\
\hline & $1597-9$ & $\begin{array}{l}\text { CCALS: DSS } 1 / 7 / 6 / 46 ; \\
\text { CCALS: DSS } 1 / 7 / 6 / \\
\text { 45; \& CCALS: DSS } \\
\text { 1/7/11/22 }\end{array}$ & $\begin{array}{l}\text { Disbursements for Mary } \\
\text { Somerford, Somerford }\end{array}$ & $\begin{array}{l}\text { 'Lute' and 'luttes', also with } \\
\text { lute strings \& wire }\end{array}$ \\
\hline & 1608 & $\begin{array}{l}\text { BI: Probate Register } \\
\quad \text { Vol.30 }\end{array}$ & $\begin{array}{l}\text { Will of Francis Fitton, } \\
\text { Esquire, Gawsworth }\end{array}$ & 'a Lute' \\
\hline & 1612 & CCALS: WS 1612 & $\begin{array}{l}\text { Inventory of John Yardley, } \\
\text { Gentleman, Crewe }\end{array}$ & 'one lute with a Case' \\
\hline & 1622 & CCALS: WS 1622 & $\begin{array}{l}\text { Inventory of Richard Heyes, } \\
\text { Gentleman, Nantwich }\end{array}$ & '4 lootes' \\
\hline & $1625-7$ & $\begin{array}{l}\text { CCALS: WS } 1625 \& \\
\text { CCALS: WS } 1627\end{array}$ & $\begin{array}{l}\text { Inventory of Edmond Myles, } \\
\text { Innkeeper (1625) and his }\end{array}$ & 'twoe Lutes' \\
\hline
\end{tabular}


Continued

\begin{tabular}{|c|c|c|c|c|}
\hline Location & Year & $\begin{array}{l}\text { Repository and Shelf } \\
\text { mark }\end{array}$ & Record details & Lute details \\
\hline & \multicolumn{4}{|c|}{$\begin{array}{l}\text { widow Elizabeth Myles } \\
\text { (1627), Nantwich }\end{array}$} \\
\hline & 1629 & $\begin{array}{l}\text { CCALS: DSS } 1 / 4 / 38 / 12 \\
\text { \& CCALS: DSS } 1 / 4 / \\
38 / 13\end{array}$ & $\begin{array}{l}\text { Letters of Margaret Lowther } \\
\text { to Elizabeth Winnington }\end{array}$ & 'my. lute: and: som strings' \\
\hline \multirow[t]{3}{*}{$\begin{array}{l}\text { County } \\
\text { Durham }\end{array}$} & $1596-1609$ & $\begin{array}{l}\text { P.C.C. } 34 \text { Dorset / } \\
\text { C.142.311, sec. } 109\end{array}$ & $\begin{array}{l}\text { Inventories of John Lumley, } \\
\text { First Baron Lumley, } \\
\text { Lumley Castle }\end{array}$ & 'Lutes viii' \\
\hline & 1605 & $\begin{array}{l}\text { DUL: DPRI/1/1605/S1/ } \\
\quad 1-3\end{array}$ & $\begin{array}{l}\text { Will of Francis Saire, } \\
\text { mercer, Barnard Castle }\end{array}$ & 'my lute' \\
\hline & 1623 & $\begin{array}{l}\text { DUL: DPRI/1/1623/T8/ } \\
\quad 1-3\end{array}$ & $\begin{array}{l}\text { Will of Thomas Trotter, } \\
\text { gentleman, Esh, } \\
\text { Wolsingham }\end{array}$ & 'my Lute' \\
\hline \multirow[t]{3}{*}{ Derbyshire } & 1602 & Hardwick MS 10A & $\begin{array}{l}\text { Accounts of Sir William } \\
\text { Cavendish (1597-1602) }\end{array}$ & 'treble lute' \\
\hline & 1603 & Hardwick MS 10B & $\begin{array}{l}\text { Accounts of Sir William } \\
\text { Cavendish (1597-1608), } \\
\text { Payments to Thomas } \\
\text { Oates, chaplain to Lady } \\
\text { Arbella, Hardwick Hall }\end{array}$ & $\begin{array}{l}\text { 'nyne knottes of mynikins } \\
\text { for the lute'; 'a midling } \\
\text { lute of } 14 \text { strings' }\end{array}$ \\
\hline & $1610-14$ & Hardwick MS 29 & $\begin{array}{l}\text { Accounts of Sir William } \\
\text { Cavendish }\end{array}$ & 'lute'; books for 'three lutes' \\
\hline Devonshire & 1602 & $\begin{array}{l}\text { Chatsworth, } \\
\text { Devonshire MS } 23\end{array}$ & $\begin{array}{l}\text { Payment to Mr Starkey for } \\
\text { the transportation of } \\
\text { instruments from } \\
\text { London to Hardwick }\end{array}$ & 'treble lute' \\
\hline Dorset & 1586 & $\begin{array}{l}\text { CRO: AR/21/21/2; \& } \\
\text { CRO: AR/21/22 }\end{array}$ & $\begin{array}{l}\text { Will and inventory of } \\
\text { Edward Arundell, } \\
\text { Lanherne }\end{array}$ & $\begin{array}{l}\text { 'my best lute' (made 'of } \\
\text { white and blacke bone') } \\
\text { with case and lute strings }\end{array}$ \\
\hline \multirow[t]{2}{*}{ Essex } & 1608 & ERO: D/DP. E.2.I & $\begin{array}{l}\text { Note of Books and } \\
\text { Instruments delivered to } \\
\text { Richard Mico }\end{array}$ & 'my Lords lute' \\
\hline & 1634 & ERO: D/DP. F.224 & Inventory of West Thorndon & $\begin{array}{l}\text { 'a short neckt lute, two long } \\
\text { neckt lutes with cases' } \\
\text { (these latter two } \\
\text { instruments are surely } \\
\text { theorboes, but are } \\
\text { included here due to the } \\
\text { description 'lutes') }\end{array}$ \\
\hline Hertfordshire & 1608 & $\begin{array}{l}\text { CFEP: Bills } 33 \& \\
\text { Accounts } 160 / 1\end{array}$ & $\begin{array}{l}\text { Endorsements, bills and } \\
\text { accounts for Hatfield } \\
\text { House, Payments to } \\
\text { Nicholas Lanier }\end{array}$ & 'a lute' \\
\hline \multirow[t]{3}{*}{ Kent } & 1615 & PRC: $10 / 43$, No.44 & $\begin{array}{l}\text { Inventory of Nathaniel Ely, } \\
\text { clerk, Biddenden }\end{array}$ & 'ii lewites’ \\
\hline & 1617 & PRC: $28 / 9$, fo. 446 & $\begin{array}{l}\text { Inventory of Nicholas } \\
\text { Parker, Esquire, } \\
\text { Canterbury }\end{array}$ & 'two old Lutes' \\
\hline & 1617 & PRC: $28 / 9$, fo. 614 & $\begin{array}{l}\text { Inventory of John Warde, } \\
\text { petty canon, Canterbury }\end{array}$ & 'an old Lute' \\
\hline
\end{tabular}


Continued

\begin{tabular}{|c|c|c|c|c|}
\hline Location & Year & $\begin{array}{l}\text { Repository and Shelf } \\
\text { mark }\end{array}$ & Record details & Lute details \\
\hline & 1630 & PRC: $28 / 15$ No.166 & $\begin{array}{l}\text { Inventory of William } \\
\text { Wentworth, Gentleman, } \\
\text { Dover }\end{array}$ & 'old broken Lute' \\
\hline & 1631 & PRC: 28/17 No.114 & $\begin{array}{l}\text { Inventory of George } \\
\text { Marson, Master of the } \\
\text { Choristers, Organist, and } \\
\text { Petty Canon at } \\
\text { Canterbury Cathedral }\end{array}$ & 'an old Lute' \\
\hline \multirow[t]{6}{*}{ Lancashire } & $1614-15$ & LRO: WCW 1614 & $\begin{array}{l}\text { Will and inventory of } \\
\text { Edward Stockley, Prescot }\end{array}$ & 'one Lute' \\
\hline & 1621 & LRO: DDKs $18 / 9$ & $\begin{array}{l}\text { Household accounts of Sir } \\
\text { Richard Shuttleworth 12, } \\
\text { Smithills, and Gawthorpe }\end{array}$ & $\begin{array}{l}\text { 'a Lute booke' and 'a Lute } \\
\text { and case' }\end{array}$ \\
\hline & 1623 & LRO: WCW 1630 & $\begin{array}{l}\text { Inventory of Thurstan } \\
\text { Collinson } \\
\text { (schoolmaster), } \\
\text { Blackburn }\end{array}$ & 'one lute' \\
\hline & 1625 & PRO: PROB 10 Box 439 & $\begin{array}{l}\text { Will of Richard Fleetwood, } \\
\text { Penwortham }\end{array}$ & 'both my lutes' \\
\hline & 1627 & $\begin{array}{l}\text { Hull Univ. Arch.: U } \\
\text { DDEV/69/1 }\end{array}$ & $\begin{array}{l}\text { Will of Richard Sherburne of } \\
\text { Stonihurst, co. Lancs }\end{array}$ & 'my little Lute' \\
\hline & 1634 & LRO: WCW 1634 & $\begin{array}{l}\text { Inventory of Sir Cuthbert } \\
\text { Clifton, Lytham }\end{array}$ & 'one Lute' \\
\hline \multirow[t]{3}{*}{ Leicestershire } & 1588 & $\begin{array}{l}\text { HMC: Rutland MSS, i, } \\
\quad 250\end{array}$ & $\begin{array}{l}\text { Letter from Elizabeth } \\
\text { Manners to the Countess } \\
\text { of Bedford, Belvoir Castle }\end{array}$ & 'the lute' \\
\hline & 1600 & $\begin{array}{l}\text { HMC: Rutland MSS, iv, } \\
\quad 432\end{array}$ & $\begin{array}{l}\text { Disbursements for Lady } \\
\text { Fraunces Manners, } \\
\text { Belvoir Castle }\end{array}$ & $\begin{array}{l}\text { 'a lute', 'a lute booke', and } \\
\text { lute strings }\end{array}$ \\
\hline & $1617-20$ & $\begin{array}{l}\text { HMC: Rutland MSS, iv, } \\
\text { 513, \& } 518\end{array}$ & $\begin{array}{l}\text { Account of William Sexten, } \\
\text { Forrend Payments (1617) } \\
\text { \& London Payements } \\
\text { (1620), Belvoir Castle }\end{array}$ & 'his lute'; 'a lute' \\
\hline \multirow[t]{2}{*}{ Lincolnshire } & 1583 & LA: 2 ANC 14/18 & $\begin{array}{l}\text { Peregrine Bertie's } \\
\text { Household Accounts, } \\
\text { Grimsthorpe }\end{array}$ & 'a lute' \\
\hline & $1588-9$ & LA: INV 75/271 & $\begin{array}{l}\text { Inventory of Edward } \\
\text { Rockadyne, Scrivener, } \\
\text { Lincoln }\end{array}$ & 'one old lute' \\
\hline Nottingham & 1601 & Nott.U.L.: Mi. I. 15 & $\begin{array}{l}\text { Inventory of the Willoughby } \\
\text { Family, Wollaton Hall }\end{array}$ & '2 lutes' \\
\hline \multirow[t]{2}{*}{ Norwich } & 1587 & NRO: DN/INV 3/60 & Will of Richard Keye, grocer & 'one lute' \\
\hline & 1599 & NRO: DN/INV 16/194a & $\begin{array}{l}\text { Inventory of Hubert Hacon, } \\
\text { gentleman, at Norwich } \\
\text { and Wheatacre }\end{array}$ & $\begin{array}{l}\text { Norwich: 'viij Lut[es]' } \\
\text { ('whereof ii' belong to } \\
\text { John Hacon) } \\
\text { Wheatacre: 'ii xiiii stringe } \\
\text { lut[es]' }\end{array}$ \\
\hline
\end{tabular}


Continued

\begin{tabular}{|c|c|c|c|c|}
\hline Location & Year & $\begin{array}{l}\text { Repository and Shelf } \\
\text { mark }\end{array}$ & Record details & Lute details \\
\hline & 1605 & $\begin{array}{l}\text { NRO: NCC original will } \\
1605 \text { no. } 64\end{array}$ & $\begin{array}{l}\text { Will of Matthew Wilby } \\
\text { senior, tanner, of Diss, } \\
\text { Norfolk }\end{array}$ & 'my lute' \\
\hline & 1617 & NRO: DN/INV 29/121 & $\begin{array}{l}\text { Will of Thomas Garneys, } \\
\text { gentleman, Norwich } \\
\text { Cathedral Precinct }\end{array}$ & 'one olde lute' \\
\hline & $1617-25$ & $\begin{array}{l}\text { NRO: 28/88; NRO: NCC } \\
\text { Will Register 304/ } \\
\text { Belward; \& NRO: } 32 / \\
262\end{array}$ & $\begin{array}{l}\text { Inventory (1617-18) of } \\
\text { Edward Jefferies, } \\
\text { musician, and Will (1619) } \\
\text { and Inventory (1625) of } \\
\text { Susan Jefferies, Norwich }\end{array}$ & $\begin{array}{l}\text { 'one ould Lute' and also } \\
\text { 'one Lute'; the latter } \\
\text { instrument may be the } \\
\text { same as the 'one goode } \\
\text { Treble Lute' Susan } \\
\text { requests in } 1619\end{array}$ \\
\hline & 1618 & $\begin{array}{l}\text { Nat. Arch: PROB/11/ } \\
131 / 656\end{array}$ & $\begin{array}{l}\text { Will of Sir Edward } \\
\text { Blenhaysett of Norwich }\end{array}$ & 'one Lute' \\
\hline \multirow[t]{11}{*}{ Oxfordshire } & 1588 & $\begin{array}{l}\text { OHC: MSS.Wills Oxon. } \\
\text { 297/4/19 }\end{array}$ & $\begin{array}{l}\text { Inventory of Anthony Hall, } \\
\text { gentleman, South } \\
\text { Newington }\end{array}$ & 'an old lute' \\
\hline & 1592 & OUA: HYP/B/10 & $\begin{array}{l}\text { Inventory of Francis Betts, } \\
\text { fellow of New College, } \\
\text { Oxford }\end{array}$ & 'a Lute' \\
\hline & 1594 & $\begin{array}{l}\text { OHC: MSS.Wills Pec. } \\
\quad 48 / 1 / 8\end{array}$ & $\begin{array}{l}\text { Inventory of William } \\
\text { Penton, tanner, Banbury }\end{array}$ & 'a lute' \\
\hline & 1594 & $\begin{array}{l}\text { Longleat, Thynne } \\
\text { papers, Box } 32 \\
\text { (= vol. (xxix) }\end{array}$ & $\begin{array}{l}\text { Inventory of items left at } \\
\text { Oxford by Thomas } \\
\text { Thynne of Longleat, } \\
\text { Wiltshire }\end{array}$ & 'a lute \& a lute booke' \\
\hline & 1602 & OUA: HYPO/B/16 & $\begin{array}{l}\text { Inventory of John Mathew, } \\
\text { 'singingman' at Christ } \\
\text { Church, Oxford }\end{array}$ & 'Eleven Lutes' \\
\hline & 1608 & OUA: HYP/B/10 & $\begin{array}{l}\text { Chancellor's Court } \\
\text { Inventories (Inventory of } \\
\text { Nicholas Bond), Oxford }\end{array}$ & ‘ij Lutes’ \\
\hline & 1610 & OUA: HYP/B/10 & $\begin{array}{l}\text { Inventory of Richard } \\
\text { Baylye, fellow of All Souls } \\
\text { College, Oxford }\end{array}$ & 'one lute' \\
\hline & 1611 & OUA: HYP/B/10 & $\begin{array}{l}\text { Inventory of William Atkins, } \\
\text { butler of Broadgate Hall, } \\
\text { Oxford }\end{array}$ & 'a lute' \\
\hline & 1612 & OUA: HYP/B/16 & $\begin{array}{l}\text { Inventory of Robert Mallett, } \\
\text { manciple of Edmund Hall } \\
\text { and instrument maker, } \\
\text { Oxford }\end{array}$ & 'a flatbackt lute \& case' \\
\hline & 1616 & OUA: HYP/B/14 & $\begin{array}{l}\text { Inventory of Robert } \\
\text { Huniman, 'clark' of } \\
\text { Magdalen College, } \\
\text { Oxford }\end{array}$ & 'a lute' \\
\hline & $1626-7$ & QC Library: MS 390 & $\begin{array}{l}\text { Thomas Crosfield's diary, } \\
\text { Oxford }\end{array}$ & 'Lutes' \\
\hline
\end{tabular}


Continued

\begin{tabular}{|c|c|c|c|c|}
\hline Location & Year & $\begin{array}{l}\text { Repository and Shelf } \\
\text { mark }\end{array}$ & Record details & Lute details \\
\hline & 1627 & $\begin{array}{l}\text { OHC: MSS.Wills Pec. } \\
\text { 33/1/4 }\end{array}$ & $\begin{array}{l}\text { Inventory of Mathew } \\
\text { Bentley, mercer, Banbury }\end{array}$ & 'lute' \\
\hline & 1631 & $\begin{array}{l}\text { Lyte: 'MSS of Earl of } \\
\text { Kilmorey' }\end{array}$ & $\begin{array}{l}\text { Inventory of Goods of } \\
\text { Robert Needham, } 1^{\text {st }} \\
\text { Viscount Kilmorey, } \\
\text { Shavington }\end{array}$ & 'one lute' \\
\hline & 1631 & OUA: HYP/B/12 & $\begin{array}{l}\text { Inventory of John Dodd, } \\
\text { fellow of Exeter College, } \\
\text { Oxford }\end{array}$ & 'a Lute $w^{\text {th }}$ a case' \\
\hline & 1633 & OUA: HYP/B/13 & $\begin{array}{l}\text { Inventory of William } \\
\text { Higgins, Christ Church } \\
\text { College, Oxford }\end{array}$ & 'One Lute' \\
\hline & 1635 & OUA: HYP/B/13 & $\begin{array}{l}\text { Inventory of William } \\
\text { Pickering of Trinity } \\
\text { College, Oxford }\end{array}$ & 'a lute and Case' \\
\hline & $1635-6$ & OUA: HYP/B/13 & $\begin{array}{l}\text { Chancellor's Court } \\
\text { Inventories (Inventory of } \\
\text { John Gerrard, university } \\
\text { musician), Oxford }\end{array}$ & 'two Lutes' \\
\hline Plymouth & 1598 & PRO: C.2/33/96 & $\begin{array}{l}\text { Legal dispute Richard } \\
\text { Drake v Jonas } \\
\text { Bodenham, members of } \\
\text { Francis Drake's crew, } \\
\text { concerning items } \\
\text { removed from the ship } \\
\text { Defiance }\end{array}$ & 'a lute' \\
\hline \multirow[t]{5}{*}{ Somerset } & $1605-6$ & $\begin{array}{l}\text { Dulwich College MS III } \\
\quad \text { f21 }\end{array}$ & $\begin{array}{l}\text { Letter from John Poyntz to } \\
\text { Edward Alleyn asking for } \\
\text { return of his lute }\end{array}$ & 'my lute' \\
\hline & $1607-8$ & PRO: STAC $8 / 161 / 1$ & $\begin{array}{l}\text { Examination of William } \\
\text { Evans, Schoolmaster, } \\
\text { Wells }\end{array}$ & 'the Lute' \\
\hline & 1617 & SRO: DD/TMP 8 & $\begin{array}{l}\text { Court and Tithe Book, } \\
\text { Merriott }\end{array}$ & 'his lute', 'my lute' \\
\hline & 1622 & PRO: PROB 11/140 & $\begin{array}{l}\text { Will of Christopher Brice, } \\
\text { Woolverton }\end{array}$ & 'my two lutes' \\
\hline & 1626 & $\begin{array}{l}\text { Register of Dulwich } \\
\text { College 1616-1757, } \\
\text { Dulwich College } \\
\text { MS X }\end{array}$ & $\begin{array}{l}\text { Will of Edward Alleyn, actor, } \\
\text { Dulwich }\end{array}$ & 'a Lute' \\
\hline Suffolk & 1603 & $\begin{array}{l}\text { CUA: Hengrave Hall } \\
\text { MS } 81\end{array}$ & $\begin{array}{l}\text { Inventory of Sir Thomas } \\
\text { Kytson and Lady } \\
\text { Elizabeth Cornwallis, } \\
\text { Hengrave Hall }\end{array}$ & $\begin{array}{l}\text { 'one great base lewte, and a } \\
\text { meane lewte, both } \\
\mathrm{w}^{\text {th }} \text { out cases' and 'one } \\
\text { trebble lute and a meane } \\
\text { lute with cases' }\end{array}$ \\
\hline Surrey & 1605 & $\begin{array}{l}\text { Nat.Arch: PROB } \\
\text { 10/232 }\end{array}$ & $\begin{array}{l}\text { Will of Augustine Phillips, } \\
\text { Gentleman of Mortlake, } \\
\text { Surrey }\end{array}$ & 'a lute' \\
\hline Sussex & $1627-8$ & DRO: D/FSI: box 222 & $\begin{array}{l}\text { Judith Edwards' Cashbook, } \\
\text { Fayre Crooch }\end{array}$ & $\begin{array}{c}\text { 'the lute' (also referred to as } \\
\text { 'a lute') and lute strings }\end{array}$ \\
\hline
\end{tabular}


Continued

\begin{tabular}{|c|c|c|c|c|}
\hline Location & Year & $\begin{array}{l}\text { Repository and Shelf } \\
\text { mark }\end{array}$ & Record details & Lute details \\
\hline & $1634-8$ & BL Add MS 33145 & $\begin{array}{l}\text { Sir Thomas Pelham's } \\
\text { accounts, Halland Place }\end{array}$ & $\begin{array}{l}\text { 'the lute' and lute strings; } \\
\text { payments for 'a lute' and } \\
\text { also to various lute } \\
\text { masters }\end{array}$ \\
\hline Warminster & $1610-12$ & $\begin{array}{l}\text { Longleat House, MS. } \\
\qquad 268\end{array}$ & $\begin{array}{l}\text { Sir Thomas Thynne's } \\
\text { accounts, Longleat, } \\
\text { Wiltshire }\end{array}$ & 'a lute'; 'the lute' \\
\hline \multirow[t]{2}{*}{ Warwickshire } & 1588 & $\begin{array}{l}\text { Longleat House, } \\
\text { Dudley MS X }\end{array}$ & $\begin{array}{l}\text { Inventory of Robert Dudley, } \\
\text { Earl of Leicester at } \\
\text { Kenilworth Castle, } \\
\text { Kenilworth }\end{array}$ & $\begin{array}{l}\text { 'Three lutes, in leather } \\
\text { cases' }\end{array}$ \\
\hline & $1608-18$ & $\begin{array}{l}\text { WCRO: various B } \\
\text { series docs }\end{array}$ & $\begin{array}{l}\text { Household accounts of the } \\
\text { Newdegate family }\end{array}$ & $\begin{array}{l}\text { 'a lute for Jack' (1608-14) } \\
\text { and 'a Lute for Mr John' } \\
\text { (1618), together with } \\
\text { various payments for } \\
\text { repairs and strings }\end{array}$ \\
\hline Westmorland & $1616-17$ & $\begin{array}{l}\text { CH: Bolton Abbey MS } \\
\quad 97\end{array}$ & $\begin{array}{l}\text { Household Accounts } \\
\text { Clifford }\end{array}$ & 'the lute' \\
\hline Worcestershire & 1622 & $\begin{array}{l}\text { WAAS 008.7. BA3585/ } \\
\quad 1622 / 166 a\end{array}$ & $\begin{array}{l}\text { Inventory of Stephen } \\
\text { Maylard, Chapter Clerk of } \\
\text { Worcester Cathedral }\end{array}$ & 'twoe lute' \\
\hline \multirow[t]{2}{*}{ Wales } & 1619 & NLW: NLW MS 9053E & $\begin{array}{l}\text { Sir John Wynn's } \\
\text { Instructions for London } \\
\text { Purchases, Gwydir }\end{array}$ & 'a Laute' \\
\hline & $1626-7$ & NLW: NLW MS 9061E & $\begin{array}{l}\text { Sir John Wynn's Personal } \\
\text { Notes, Gwydir }\end{array}$ & $\begin{array}{l}\text { 'his lute' (also referred to as } \\
\text { 'a lute') }\end{array}$ \\
\hline
\end{tabular}

Note. This table aims to give a representative overview (and as comprehensive as possible) of lute ownership across the period in question; it excludes references to lute strings and/or lute books unless these are explicitly listed with a lute, and it also omits the other instruments that are sometimes listed alongside these lutes. The repository and shelf mark abbreviations follow the format used in 'Records of Early English Drama'.

Source. In addition to several references generously supplied by Michael Fleming, this list was compiled with the aid of staff in the Hull History Centre, Norwich Records Office, Durham Record Office / Durham University Library, Oxfordshire History Centre, Worcestershire Archive and Archaeology Service, and Dulwich College. In addition, the following sources were used: the multivolume collections of 'Records of Early English Drama' (REED, 1979-), http://reed.utoronto.ca; 'The Henslowe-Allen Digitisation Project', https://henslowe-alleyn.org.uk; Lionel Cust, 'The Lumley Inventories', Walpole Society, 6 (1918), 15-35; Michael Fleming, 'Some Points Arising from a Survey of Wills and Inventories', The Galpin Society Journal, 53 (2000), 301-11; Michael Fleming, 'Unpacking the 'Chest of Viols", Chelys, 28 (2000), 3-19; Michael Gale, 'Learning the Lute in Early Modern England c.1550-C.1640' (Ph.D. diss., University of Southampton, 2014); Historical Manuscripts Commission (HMC), The Manuscripts of his Grace the Duke of Rutland GCB Preserved at Belvoir Castle, 4 vols (London: HMSO, 1888-1905); Peter Holman, Four and Twenty Fiddlers: The Violin at the English Court 1540-1690 (Oxford: Clarendon Press, 1993); Lynn Mary Hulse, 'The Musical Patronage of the English Aristocracy, c.15901640' (Ph.D. diss., King's College, University of London, 1992); Elisabeth Leedham-Green, Books in Cambridge Inventories; Teresa Ann Murray, 'Thomas Morley and the Business of Music in Elizabethan England' (Ph.D. diss., University of Birmingham, 2010); Tessa Murray, Thomas Morley: Elizabethan Music Publisher; David C. Price, Patrons and Musicians of the English Renaissance (Cambridge: Cambridge University Press, 1981). 


\section{APPENDIX 1b}

REFERENCES to LUTES in COURT RECORDS 1585-1635.

\begin{tabular}{|c|c|c|}
\hline Year & Source details & Lute details \\
\hline 1589 & $\begin{array}{l}\text { November: A discharge of the two subsidies granted at the last } \\
\text { Parliament (VI, 52) }\end{array}$ & 'lutes' \\
\hline 1593 & $\begin{array}{l}\text { June 27: List of musicians excused payment of subsidies granted on } 19 \\
\text { February } 1592 / 3(\mathrm{VI}, 59)\end{array}$ & 'lutes’ \\
\hline $1594 / 5$ & $\begin{array}{l}\text { January 25: Lease in reversion to Alice Johnson, widow of Robert } \\
\text { Johnson (VIII, 46-7) }\end{array}$ & 'the lute' \\
\hline 1598 & October 22: Lay Subsidy Roll (VI, 67) & 'The Lutes' \\
\hline 1599 & June 18: Grant to Edward Collard (VIII, 49) & 'the three lutes' \\
\hline $1600-1$ & Michaelmas 1600-Michaelmas 1601: Payments to musicians (VI, 163) & 'Lutes' \\
\hline $1601-2$ & Michaelmas 1601-Michaelmas 1602: Payments to musicians (VI, 164) & 'Lutes' \\
\hline 1602 & April 29: Lay Subsidy Roll (VI, 72) & 'Luttes' \\
\hline $1602-3$ & $\begin{array}{l}\text { Michaelmas 1602-Michaelmas 1603: Payments to musicians (IV, } 73 \text { and VI, } \\
\text { 166) }\end{array}$ & 'Lutes' \\
\hline \multirow[t]{3}{*}{1603} & $\begin{array}{l}\text { April 28: Funeral of Queen Elizabeth I at Westminster Abbey; allowances } \\
\text { of mourning liveries to musicians (IV, } 1,2 \text { ) }\end{array}$ & 'the Lute' / 'Lutes' \\
\hline & May 18: Swearing in of servants of James I by Gentlemen Ushers (IV, 231) & 'Lutes' \\
\hline & $\begin{array}{l}\text { July 25: Wardrobe Account for the coronation of James I and Anne of } \\
\text { Denmark (IV, 232) }\end{array}$ & '2 Lutes’ \\
\hline $1603-4$ & Michaelmas 1603-Michaelmas 1604: Payments to musicians (IV, 74) & 'Lutes' \\
\hline 1604 & $\begin{array}{l}\text { November 8: Warrant to Treasurer of the Chamber to pay Philip Rosseter } \\
(\text { VIII, 56) }\end{array}$ & 'the lutes' \\
\hline $1604-5$ & Michaelmas 1604-Michaelmas 1605: Payments to musicians (IV, 76) & 'Lutes' \\
\hline $1605-6$ & Michaelmas 1605-Michaelmas 1606: Payments to musicians (IV, 77) & 'Lutes' \\
\hline 1606 & June 22: A remission for his Majesty's servants (IV, 13) & 'lutes’ \\
\hline $1606-7$ & Michaelmas 1606-Michaelmas 1607: Payments to musicians (IV, 79) & 'Lutes' \\
\hline 1607 & $\begin{array}{l}\text { August 28, September 5, and October 1: Declared Accounts of Sir George } \\
\text { Carew, Receiver General to Queen Anne of Denmark, Gifts and Rewards } \\
\text { (IV, 198-9) }\end{array}$ & $\begin{array}{l}\text { 'a brasse Lute' [sic] / 'the } \\
\text { Lute' / 'a little lute' }\end{array}$ \\
\hline $1607-8$ & Michaelmas 1607-Michaelmas 1608: Payments to musicians (IV, 80-1) & 'Lutes' \\
\hline 1608 & April 19: Damaged subsidy lists for the Royal Household (IV, 18, 20) & 'The Lutes' / 'The Lute' \\
\hline 1608 & $\begin{array}{l}\text { June 30: Payment to 'Phillipp Rosseter, one of his Ma }{ }^{\text {ts }} \text { Musitions' for new } \\
\text { lute and lute strings (IV, } 81 \text { ) }\end{array}$ & 'a new lute' \\
\hline $1608-9$ & Michaelmas 1608-Michaelmas 1609: Payments to musicians (IV, 83) & 'Lutes' \\
\hline \multirow[t]{2}{*}{$1609-10$} & March 20: Subsidy list for the Royal Household (IV, 26) & 'The Lute' \\
\hline & Michaelmas 1609-Michaelmas 1610: Payments to musicians (IV, 85) & 'Lutes' \\
\hline
\end{tabular}


Continued

\begin{tabular}{|c|c|c|}
\hline Year & Source details & Lute details \\
\hline \multirow[t]{2}{*}{1610} & $\begin{array}{l}\text { April } 7 \text { and May 10: Warrant Dormant under the Signet to Treasurer of the } \\
\text { Chamber (VIII, 63) and payment to Symon Marson (IV, 86) }\end{array}$ & 'lute' / 'a newe Lute' \\
\hline & $\begin{array}{l}\text { December 28: Account of sums paid by the Treasurer of the Chamber (VIII, } \\
64 \text { ) }\end{array}$ & 'the lute' \\
\hline \multirow[t]{2}{*}{$1610-11$} & January 10,1610 [/11]: Payment to Robert Johnson for lute strings (IV, 87) & 'the base Lute"* \\
\hline & Michaelmas 1610-Michaelmas 1611: Payments to musicians (IV, 87) & 'Lutes’ \\
\hline $1610-12$ & $\begin{array}{l}1 \text { October 1610-6 November 1612: Privy Purse Accounts of Sir David } \\
\text { Murray (IV, 215) }\end{array}$ & 'twoe lutes' / 'Lute' \\
\hline \multirow[t]{2}{*}{1611} & June 5: Payments to Roberte Johnson for a lute and lute strings (IV, 88) & 'a lute' / 'the base lute' \\
\hline & $\begin{array}{l}\text { July 7: Warrant Dormant to Treasurer of the Chamber to disburden the } \\
\text { Privy Purse of divers payments (VIII, 65) }\end{array}$ & 'lutes' \\
\hline \multirow[t]{2}{*}{$1611-12$} & Michaelmas 1611-Michaelmas 1612: Payments to musicians (IV, 89) & 'Lutes’ \\
\hline & January 10,1611 [/12]: Payment to Robert Johnson for lute strings (IV, 89) & 'his Mats Base Lute"* \\
\hline 1612 & April 3: Grant to Thomas Warren (VIII, 66) & ‘lute-player’ \\
\hline $1612-13$ & Michaelmas 1612-Michaelmas 1613: Payments to musicians (IV, 90-1) & ‘Lutes’ \\
\hline $1613-14$ & Michaelmas 1613-Michaelmas 1614: Payments to musicians (IV, 93) & 'Lutes’ \\
\hline $1614-15$ & Michaelmas 1614-Michaelmas 1615: Payments to musicians (IV, 94) & 'Lutes’ \\
\hline $1615-16$ & Michaelmas 1615-Michaelmas 1616: Payments to musicians (IV, 96) & 'Lutes’ \\
\hline $1616-17$ & Michaelmas 1616-Michaelmas 1617: Payments to musicians (IV, 98) & ‘Lutes’ \\
\hline \multirow[t]{2}{*}{1617} & Arrears from 1 October 1617 to 30 September 1623 (IV, 100) & 'Lutes' \\
\hline & December 29: Payment to Phillip Rosseter for lute strings (IV, 101) & 'the base Lute"* \\
\hline $1617-18$ & Michaelmas 1617-Michaelmas 1618: Payments to musicians (IV, 101) & 'Lutes' \\
\hline 1618 & $\begin{array}{l}\text { November 9: Declared Accounts of Adam Newton, Receiver General to } \\
\text { Prince Charles, warrant dormant to Thomas Meller (IV, 223) }\end{array}$ & 'his Highness' lutes' \\
\hline \multirow[t]{2}{*}{ 1618-19 } & Michaelmas 1618-Michaelmas 1619: Payments to musicians (IV, 103) & 'Lutes’ \\
\hline & $\begin{array}{l}12 \text { February: Receivers General Accounts of Prince Charles, bill of } \\
\text { payments to Robert Johnson (IV, 219) }\end{array}$ & $\begin{array}{l}\text { 'a Lute' / 'the base lute' / } \\
\text { 'the lutes' }\end{array}$ \\
\hline 1619 & $\begin{array}{l}\text { Declared accounts of Adam Newton, Receiver General to Prince Charles, } \\
\text { payment to Thomas Meller (IV, 222) }\end{array}$ & 'his Highness' lutes' \\
\hline $1619-20$ & Michaelmas 1619-Michaelmas 1620: Payments to musicians (IV, 106) & 'Lutes' \\
\hline \multirow[t]{2}{*}{1620} & December 28: Payment to Phillippe Roseter for bass lute strings (IV, 109) & 'the base lutes”* \\
\hline & December 28: Payment to Roberte Johnson for lute strings (IV, 109) & 'his Ma"s Lutes'* \\
\hline $1620-1$ & Michaelmas 1620-Michaelmas 1621: Payments to musicians (IV, 108) & 'Lutes’ \\
\hline $1621-2$ & Michaelmas 1621-Michaelmas 1622: Payments to musicians (IV, 110) & 'Lutes’ \\
\hline \multirow[t]{2}{*}{1621} & $\begin{array}{l}\text { June 26: Declared Accounts of Adam Newton, payment to Thomas Meller } \\
\text { (IV, 224) }\end{array}$ & 'his Highness' lutes' \\
\hline & December 28: Payment to Phillip Rosseter for bass lute strings (IV, 110) & 'the base Lute`* \\
\hline 1622 & Declared Accounts of Adam Newton, payment to Thomas Meller (IV, 225) & 'his Highness' lutes' \\
\hline
\end{tabular}


Continued

\begin{tabular}{|c|c|c|}
\hline Year & Source details & Lute details \\
\hline \multirow[t]{2}{*}{$1622-3$} & $\begin{array}{l}\text { January 6, 1622/3: Payment to Phillip Rosseter for strings and 'other } \\
\text { necessaryes' for the bass lute and Robert Johnson for lute strings } \\
\text { (IV, 113) }\end{array}$ & 'the base lute' / 'lutes'* \\
\hline & Michaelmas 1622-Michaelmas 1623: Payments to musicians (IV, 112) & 'Lutes' \\
\hline \multirow[t]{2}{*}{1623} & December 30: Payment to Robert Johnson for lute strings (IV, 114) & 'the Lutes'* \\
\hline & $\begin{array}{l}\text { December 31: Payment to Maurice Webster, 'one of his Mats Musicons' for } \\
\text { strings for the bass lute (IV, 114) }\end{array}$ & 'the Base Lute'* \\
\hline $1623-4$ & Michaelmas 1623-Michaelmas 1624: Payments to musicians (IV, 114) & 'Lutes' \\
\hline \multirow[t]{6}{*}{1624} & Damaged subsidy list for the Royal Household (IV, 62) & 'The Lutes' \\
\hline & Michaelmas: Payment to Thomas Meller (IV, 228) & 'his Highness' lutes' \\
\hline & $\begin{array}{l}\text { April } 10 \text { and July 4: Payments to Robt Johnson, 'Musicon' for lute strings } \\
\text { (IV, 228) }\end{array}$ & 'his $\mathrm{H}^{\mathrm{es}}$ Lutes”* \\
\hline & $\begin{array}{l}\text { July 13: Privy Seal discharging musicians from paying three subsidies } \\
\text { (IV, 61) }\end{array}$ & 'the Lutes' \\
\hline & December 3: Warrant to John Dowland for lute and strings (III, 134) & 'a lute' \\
\hline & December 29: Warrant to Maurice Webster for lute strings (III, 134) & 'a base Lute’ \\
\hline $1624-5$ & Michaelmas 1624-Michaelmas 1625: Payments to musicians (III, 133) & 'Lutes' \\
\hline \multirow[t]{2}{*}{1625} & $\begin{array}{l}\text { Declared Accounts of Adam Newton, payments ending Lady Day 1625, } \\
\text { payment to Thomas Meller (IV, 229) }\end{array}$ & 'his Highness' lutes' \\
\hline & $\begin{array}{l}\text { December 22: List of musicians discharged from paying subsidies } \\
\quad(\text { III, } 9 \& \mathrm{~V}, 1)\end{array}$ & 'the Lute' / 'lutes' \\
\hline \multirow[t]{2}{*}{$1625-6$} & Michaelmas 1625-Michaelmas 1626: Payments to musicians (III, 136) & 'Lutes' \\
\hline & $\begin{array}{l}\text { January } 151625 \text { [/26]: Payment to Roberte Johnson for lute strings } \\
\text { (III, 136) }\end{array}$ & 'Lute' / 'his Ma ${ }^{\text {ts }}$ Lutes' \\
\hline \multirow[t]{2}{*}{1626} & $\begin{array}{l}\text { April 16: List of the Royal Household discharged from paying subsidies } \\
\text { (III, 14-15) }\end{array}$ & 'Lutes' \\
\hline & December 29: Warrant to Exchequer to pay Ann Smith (VIII, 95) & 'a lute' \\
\hline $1626-7$ & Michaelmas 1626-Michaelmas 1627: Payments to musicians (III, 138) & 'Lutes' \\
\hline 1627 & June 25: Payment to John Cogshall for lute strings (III, 138) & 'his Ma ${ }^{\text {ts }}$ Lutes'* \\
\hline $1627-8$ & Michaelmas 1627-Michaelmas 1628: Payments to musicians (III, 139) & 'Lutes' \\
\hline \multirow[t]{6}{*}{1628} & April 13: Privy Council, a pass (= passport) for Simon de Fillier (VIII, 99) & 'the lute' \\
\hline & ?May: Petition of Robert Johnson, 'one of his Ma ${ }^{\text {ts }}$ musitions' (VIII, 99-100) & 'the Lutes' \\
\hline & $\begin{array}{l}\text { July 2: Warrant 'for a hayle for y } y^{\mathrm{e}} \text { Musitions for the Lutes and voices' } \\
\text { (III, 32) }\end{array}$ & 'the Lutes' \\
\hline & $\begin{array}{l}\text { July 15: List of musicians discharged from paying the five subsidies lately } \\
\text { granted by parliament (III, 33) }\end{array}$ & 'ye lutes' \\
\hline & September 28: Subsidy List for the Royal Household (III, 35) & 'Lutes' \\
\hline & Undated: Subsidy List for the Royal Household (III, 38) & 'Lutes' \\
\hline
\end{tabular}


Continued

\begin{tabular}{|c|c|c|}
\hline Year & Source details & Lute details \\
\hline $1628-9$ & Michaelmas 1628-Michaelmas 1629: Payments to musicians (III, 140) & 'Lutes' \\
\hline \multirow[t]{2}{*}{1629} & $\begin{array}{l}\text { October 1: Order Book of the Lord Steward (under lists of carriages to be } \\
\text { allowed) }(\mathrm{V}, 6)\end{array}$ & 'Lutes' \\
\hline & December 12: Payment to Robert Johnson for lute strings (III, 141) & 'his Ma ${ }^{\text {ts }}$ Luts' $[\text { sic }]^{\star}$ \\
\hline \multirow[t]{3}{*}{$1629-30$} & $\begin{array}{l}\text { February } 21,1629 \text { [/30]: Payment to Timothie Collins, 'one of his Ma }{ }^{\text {ts }} \\
\text { Musicōns for the Lutes' (III, 143) }\end{array}$ & 'a Lute' \\
\hline & March 7: Warrant to pay Timothy Collins (III, 50) & 'a Lute' \\
\hline & Michaelmas 1629-Michaelmas 1630: Payments to musicians (III, 142) & 'Lutes' \\
\hline \multirow[t]{2}{*}{1630} & $\begin{array}{l}\text { April } 18 \text { and May 28: Warrant (III, 54) and payment (III, 141) to John } \\
\text { Coggeshall for lute and theorbo strings }\end{array}$ & $\begin{array}{l}\text { 'his Mats Lutes' / 'the four } \\
\text { lutes'* }\end{array}$ \\
\hline & Accounts of the Receiver of the King's Revenues as Prince of Wales $(V, 6)$ & 'his Majesty's lutes' \\
\hline \multirow[t]{2}{*}{$1630-31$} & $\begin{array}{l}\text { January 10: Warrant to pay John Coggeshall for lute and theorbo strings } \\
\text { (III, 57) }\end{array}$ & 'his Majesty's four lutes'* \\
\hline & Michaelmas 1630-Michaelmas 1631: Payments to musicians (III, 144) & 'Lutes' \\
\hline \multirow[t]{2}{*}{1631} & $\begin{array}{l}\text { July 8: Warrant (III, 60) and payment (III, 144) to Robert Johnson for lute } \\
\text { strings }\end{array}$ & 'lute' / 'the Lutes”* \\
\hline & $\begin{array}{l}\text { December 21: Warrant (III, 63) and payment (III, 144) to John Coggeshall } \\
\text { for lute strings }\end{array}$ & 'the lutes”* \\
\hline \multirow[t]{3}{*}{1632} & $\begin{array}{l}\text { Wages, salaries, and liveries paid by the Treasurer of his Majesty's } \\
\text { Chamber to the King's Officers and Servants (VIII, 108) }\end{array}$ & '5 lutes' \\
\hline & June 28: Warrant to pay Robert Johnson for lute strings (III, 66) & ‘his Majesty’s lutes’* \\
\hline & August 9: Signet warrant to provide yearly livery for Henry Lawes (III, 67) & 'the lutes’* \\
\hline $1632-3$ & Michaelmas 1632-Michaelmas 1633: Payments to musicians (III, 145) & 'Lutes' \\
\hline \multirow[t]{3}{*}{1633} & $\begin{array}{l}\text { April } 3 \text { and December } 1 \text { : Warrants to pay John Cogshall for 'provyding and } \\
\text { maynteyning' the royal lutes and strings (III, 146) }\end{array}$ & 'his Ma ${ }^{\text {ts }}$ Fower Lutes' \\
\hline & $\begin{array}{l}\text { December 10: Warrant to prepare a bill for the king's signature granting a } \\
\text { patent to Nicholas Duval, wages and lute strings (III, 75) }\end{array}$ & 'lutes' / 'lute' \\
\hline & $\begin{array}{l}\text { December 10: Warrant for a signet to pay yearly livery to Lewis Evans, } \\
\text { 'musician for the lutes' (III, 75) }\end{array}$ & 'the lutes' \\
\hline \multirow[t]{2}{*}{$1633-4$} & Michaelmas 1633-Michaelmas 1634: Payments to musicians (III, 147) & 'Lutes' \\
\hline & $\begin{array}{l}\text { January } 15 \text { and 19, } 1633 \text { [/34]: Payment (III, 148) and Warrant (III, 76) to } \\
\text { John Kelly and John Lawrence, 'two of his ma }{ }^{\text {ts }} \text { Musicons for the Lutes' }\end{array}$ & $\begin{array}{l}\text { 'twoe treble Lutes' / 'two } \\
\text { treble lutes' }\end{array}$ \\
\hline \multirow[t]{3}{*}{1634} & $\begin{array}{l}\text { July 10: Warrant (III, 79) and payment (III, 148) to John Lanier, 'one of his } \\
\text { Ma }^{\text {ts }} \text { Musicōns for the Lutes and voices' }\end{array}$ & 'a Lute' / 'a new lute' \\
\hline & $\begin{array}{l}\text { November 17: Payment to Maurice Webster, 'one of his mats Musicōns for } \\
\text { the Lutes' for lute strings (III, 148) }\end{array}$ & 'his ma'ts Lutes”* \\
\hline & $\begin{array}{l}\text { November 21: Payment to John Coggesgall, 'one of his mats Musitions for } \\
\text { the Lutes' for lute strings (III, 148) }\end{array}$ & 'fower Lutes'* \\
\hline $1634-5$ & Michaelmas 1634-Michaelmas 1635: Payments to musicians (III, 149) & 'Lutes’ \\
\hline
\end{tabular}


Continued

\begin{tabular}{lll}
\hline Year & Source details & Lute details \\
\hline 1635 & $\begin{array}{l}\text { June 11: Payment to Nichās Duvall, 'another of his Ma }{ }^{\text {ts }} \text { Musicōns' for a } \\
\text { lute (III, 150) }\end{array}$ & 'a Lute' \\
\cline { 2 - 3 } & $\begin{array}{l}\text { November 5: Payment to John Cogshall 'one of his Ma }{ }^{\text {ts }} \text { Musicōns' for lute } \\
\text { strings (III, 150) }\end{array}$ & 'his Mats 4 Lutes'* $^{\text {'* }}$ \\
\hline
\end{tabular}

Note. This table aims to give a representative overview of references to lutes in court archives. It generally excludes references to lute strings and/or lute books unless these provide more information about the lute's size, number, or purpose (references marked *) or unless these are explicitly listed with a lute.

Source. The information is taken from the nine-volume collection by Andrew Ashbee, ed., Records of English Court Music; the relevant volume and page number are given in brackets in the source details column.

\section{APPENDIX 2}

\section{Descriptions of a Man Singing to a Lute in English Printed Literary Sources (1595-1625)}

The following list closely follows the date range of the printed lute song collections under consideration. The literary references from this relatively narrow spectrum may be seen as representative in type and in the vocabulary used of earlier and later sources describing a male singer with lute across the period 1550-1650. This table excludes: a) references to male singing and lute with other instruments (i.e. ensemble performance); b) descriptions of a man playing a lute that do not mention him singing to it; c) references that mention a eunuch who sings to the lute; and d) texts that relate generically to singing with lute that do not specify the singer's gender or where this is unclear.

In the book titles and subheadings, words in capital letters have been rendered with small letters, but capitals have been retained at the start of words as they appear in the original. All letters have been kept as they appear in the original (including ' $u$ ' and ' $v$ '). Additions or omissions are indicated with square brackets (i.e. []). 


\begin{tabular}{|c|c|c|c|c|}
\hline Doc. & Author / Title & Publisher / Year & Page / Folio & Passage / Comments \\
\hline 1 & $\begin{array}{l}\text { William Bullein, The } \\
\text { Gouernment of Health }\end{array}$ & Valentine Sims, London, 1595 & $6^{v}$ & $\begin{array}{l}\text { Humfrey says to lohn: 'Upon my Lute some time, to recreate my } \\
\text { selfe, I ioine with my simple harmonie, many plaine verses. } \\
\text { Among all other one small song of the foure complections: wilt } \\
\text { thou heare it? take that chaire and sit downe, and I I [sic.] will } \\
\text { teach thee my song.' }\end{array}$ \\
\hline \multirow[t]{3}{*}{2} & \multirow{3}{*}{$\begin{array}{l}\text { Robert Parry, Moderatus, The } \\
\text { most delectable \& famous } \\
\text { Historie of the Blacke } \\
\text { Knight }\end{array}$} & \multirow[t]{3}{*}{$\begin{array}{l}\text { Richard Ihones [sic], London, } \\
1595\end{array}$} & Ch. $3, \mathrm{C}^{v}-\mathrm{C}^{v}\left(\right.$ at $\left.C 3^{v}\right)$ & $\begin{array}{l}\text { Priscus ' ... tooke his Lute in his hand [...and] hauing tuned his } \\
\text { instrument, began with musicall and sweete harmonie to } \\
\text { warble foorth this ensuing Dittie ...' }\end{array}$ \\
\hline & & & Ch. 4, [D2 $]^{r}-[\mathrm{D} 3]^{\mathrm{v}}$, (at [D2] $\left.]^{r}\right)$ & $\begin{array}{l}\text { Priscus ' ... tooke his Lute in his hand, to see, if with musicke he } \\
\text { could moderate his melancholie, and mollifie some of his } \\
\text { heauie passions: aud [sic.] so, like the swanne at the point of } \\
\text { death, he verie dolefully chaunted ouer this Cansong ...' }\end{array}$ \\
\hline & & & Ch. $5, \mathrm{G} 2^{v}-H 3^{r}$ & $\begin{array}{l}\text { The assembled characters (male and female) take it in turns to } \\
\text { sing songs to the lute, like a dialogue; the first man to perform is } \\
\text { Cornelius, who '... hauing tuned his Lute, warbled out this } \\
\text { ensuing Dittie ...' (sig.G2v); the second is Moderatus, who '.... } \\
\text { hauing his Lute ready for the purpose [...] began with a slow } \\
\text { and soft voyce, to measure ouer this Cansong ...' (sig.G4'); and } \\
\text { finally, Priscus '... hauing tuned his instrument to his minde, he } \\
\text { solemnely descanted vpon this ensuing Ditty ...' (sig.H3' }{ }^{r} \text { ). } \\
\text { Although not stated explicitly, Priscus probably sings to a lute } \\
\text { as well given the references to him in chapters } 3 \text { and } 4 \text {. }\end{array}$ \\
\hline \multirow[t]{2}{*}{3} & \multirow[t]{2}{*}{$\begin{array}{l}\text { Anthony Copley, Wits Fittes } \\
\text { and Fancies }\end{array}$} & \multirow[t]{2}{*}{ Richard lohnes, London, 1595} & \multirow[t]{2}{*}{ Loves Owle, $A^{r}-D 2^{v}$. } & $\begin{array}{l}\text { Loue (who is described on sig. } A^{v} \text { as a 'wretched boy' by the 'olde } \\
\text { man') says at sig.C } 3^{v} \text { : }\end{array}$ \\
\hline & & & & $\begin{array}{l}\text { '... And now in honour of accord / Vnto this Lute I will record / A } \\
\text { hymne of ioyfull lubilie, / To rowse vp thy Senechdochie / to } \\
\text { Loues actiuitie.' }\end{array}$ \\
\hline 4 & $\begin{array}{l}\text { Francis Sabie, The Fissher- } \\
\text { mans Tale }\end{array}$ & Richard lohnes, London, 1595 & $B 3^{v}$ & $\begin{array}{l}\text { An 'aged man' (a former Earl, but now a 'Fisherman') '... tooke a } \\
\text { twinkling Lute in hand [...] The only ioy of my long-hated life'. } \\
\text { His 'kindnes' towards the unnamed male narrator (through } \\
\text { whose eyes the reader experiences the passage) is to be } \\
\text { remembered in a 'ioyfull Ditty where so ere I liue'; perhaps } \\
\text { singing with a lute is implied in light of the earlier reference to } \\
\text { this instrument. }\end{array}$ \\
\hline
\end{tabular}




\begin{tabular}{|c|c|c|c|c|}
\hline Doc. & Author / Title & Publisher / Year & Page / Folio & Passage / Comments \\
\hline 5 & $\begin{array}{l}\text { Richard Turner, The Garland } \\
\text { of a greene Vitte }\end{array}$ & $\begin{array}{l}\text { [J. Roberts for] William } \\
\quad \text { Kirkham, London, ?1595 }\end{array}$ & $B^{r}$ & $\begin{array}{l}\text { Solinar, a young gentleman infatuated with Calipolis (the wife of a } \\
\text { rich merchant), took 'his Lute, first framed out some dolefull } \\
\text { tune, and hauing fitted his purpose, he fingered his pen, and in } \\
\text { a perplexed humor he writ this ditty.' }\end{array}$ \\
\hline 6 & $\begin{array}{l}\text { Richard Linche, Diella, } \\
\text { Certaine Sonnets, adioyned } \\
\text { to the amorous Poeme of } \\
\text { Dom Diego and Gineura. }\end{array}$ & $\begin{array}{l}\text { [James Roberts for] Henry } \\
\text { Olney, London, } 1596\end{array}$ & {$[B 8]^{V}$, Sonnet XV } & $\begin{array}{l}\text { Singing to the lute may be implied here; the verse is from an } \\
\text { unknown male perspective: } \\
\text { '... I walke to thinke vpon my deere; / Vhere vnder vmbrage of } \\
\text { some aged Tree, / with Lute in hand I sit and (sighing) say, / } \\
\text { Sweete Groues tell forth with Eccho what you see: ...' }\end{array}$ \\
\hline 7 & $\begin{array}{l}\text { Richard Johnson, The second } \\
\text { Part of the famous History } \\
\text { of the seauen Champions of } \\
\text { Christendome. }\end{array}$ & $\begin{array}{l}\text { [?E. Allde for] Cuthbert Burbie, } \\
\text { London, } 1597\end{array}$ & Ch. $15, \mathrm{Aa}^{\mathrm{v}}-\mathrm{Aa}^{\mathrm{r}}\left(\right.$ at $\left.A a^{\mathrm{v}}\right)$ & $\begin{array}{l}\text { 'The prince [=Pollemus] (who sate vpon the poope of the ship) } \\
\text { asked his page [=Mercutio] for his Lute, the which straight way } \\
\text { was giuen him: and when he had it in his hands, he playde and } \\
\text { sung so swéetely, that it séemed to be a most heauenly melodie } \\
\text {...' }\end{array}$ \\
\hline \multirow[t]{2}{*}{8} & $\begin{array}{l}\text { I. T., The Haven Of Pleasvre: } \\
\text { Containing a freemans } \\
\text { felicitie, and a true } \\
\text { direction how to liue well }\end{array}$ & $\begin{array}{l}\text { P.S. [=Peter Short], London, } \\
\quad 1597\end{array}$ & Ch. 14 , pp. $22-3$ & $\begin{array}{l}\text { 'Good Orpheus th':nterpretor of all the gods did fear / The sauage } \\
\text { men from murdrous facts and liues that filthie were, / And for } \\
\text { that cause was Lyons fierce and Tygers said to tame, / And } \\
\text { Amphion that builded Thebes hath also had the name, / With } \\
\text { sound of lute and pleasing words to moue \& stir the stones / } \\
\text { And lead the[m] where so ere he wold: ...' }\end{array}$ \\
\hline & & & Ch. 44, pp. $91-2$ & $\begin{array}{l}\text { Pythagoras '.... when he vvent to bed, hee vvould quiet his minde } \\
\text { vvith his lute, and pacifie his troubled affections. We reade also } \\
\text { that Epaminondas Prince of Greece, would sweetlie sing to his } \\
\text { Lute, and all Greece, as Cicero witnesseth, did thinke the depth } \\
\text { of knowledge to consist in singing and playing on instrumentes: } \\
\text { for whosoeuer was not skilful in that art, was accounted most } \\
\text { vnlearned.' }\end{array}$ \\
\hline 9 & $\begin{array}{l}\text { Thomas Rogers, Celestiall } \\
\text { Elegies of the Goddesses } \\
\text { and the Muses }\end{array}$ & $\begin{array}{l}\text { Richard Bradocke, London, } \\
1598\end{array}$ & $\begin{array}{l}\text { [Elegies of the Muses] } \\
\text { Qvatorzain. 5. Terpsichore, } \\
\text { C3 }^{\text {r }}\end{array}$ & $\begin{array}{l}\text { Written from an unknown male perspective, this verse asks: } \\
\text { 'VWHat dolefull Diapason shall I make, / What mournfull songs } \\
\text { of sorrow shall I sing' before then mentioning 'My sacred Lyre } \\
\text { that did resound of yore' which is linked to 'Phoebus Lute'. }\end{array}$ \\
\hline
\end{tabular}




\begin{tabular}{|c|c|c|c|c|}
\hline Doc. & Author / Title & Publisher / Year & Page / Folio & Passage / Comments \\
\hline 10 & $\begin{array}{l}\text { Robert Greene, rev. John } \\
\text { Dickenson, Greene In } \\
\text { Conceipt }\end{array}$ & $\begin{array}{l}\text { Richard Bradocke, London, } \\
1598\end{array}$ & $50-1$ (at 50) & $\begin{array}{l}\text { '... when after the banquet ended and the table vncouered, } \\
\text { taking his Lute, he [=Arthemio] sang to a pleasing note this } \\
\text { following dittie, more to crosse his wife, then to content his } \\
\text { wanton Mistresse ...' }\end{array}$ \\
\hline 11 & $\begin{array}{l}\text { John Marston, The Scovrge Of } \\
\text { Villanie }\end{array}$ & $\begin{array}{l}\text { I. R. [=James Roberts], } \\
\text { London, } 1598\end{array}$ & $\begin{array}{l}\text { Bk 3, Satyre. IX, }[\mathrm{G} 7]^{\mathrm{r}}-\mathrm{H} 2^{\mathrm{v}} \text { (at } \\
\left.[\mathrm{G} 8]^{\mathrm{v}}\right)\end{array}$ & $\begin{array}{l}\text { '... What hotchpotch, giberidge, doth the Poet bring? / How } \\
\text { strangely speakes? yet sweetly doth he sing. / I once did know a } \\
\text { tinckling Pewterer, / That was the vildest stumbling stutterer / } \\
\text { That euer hack'd and hew'd our natiue tongue, / Yet to the Lute } \\
\text { if you had heard him sung, / lesu how sweet he breath'd ...' }\end{array}$ \\
\hline \multirow[t]{5}{*}{12} & \multirow{5}{*}{$\begin{array}{l}\text { Marcos Martínez, trans. } \\
\text { Robert Parry (attrib.) or } \\
\text { Robert Parke (attrib.), The } \\
\text { sixth Booke of the Myrrour } \\
\text { of Knighthood. Being The } \\
\text { first Booke of the third Part }\end{array}$} & \multirow[t]{5}{*}{ Edward Allde, London, 1598} & Ch. 4, F3 ${ }^{v}-[F 4]^{r}\left(\right.$ at F3 $\left.{ }^{v}\right)$ & $\begin{array}{l}\text { Dacian ' ... tooke his Lute, his Lute that many times had yéelded } \\
\text { sad sounds to the wofull accents of his voice: and finding his } \\
\text { musike in another key, he carroled out this ditty in Loues } \\
\text { disgrace ... }\end{array}$ \\
\hline & & & Ch. $6, N 3^{r}$ & $\begin{array}{l}\text { Three princes (Rosicleer, Meridian, and Oristides) are at sea when } \\
\text { they approach another boat heading in the same direction with } \\
\text { 'a mightie Knight' in fine armour: }\end{array}$ \\
\hline & & & & $\begin{array}{l}\text { '... he was with a Lute in his hand, as one that was intended to } \\
\text { sing and play ...' }\end{array}$ \\
\hline & & & Ch. $15,[\mathrm{Hh} 4]^{r}$ & $\begin{array}{l}\text { The Lord of Dacia '... could not forget the beautie of Roselia: yet } \\
\text { loath to entertaine loue thoughts, he tooke his Lute, and to the } \\
\text { sound thereof sung in thys manner ...' }\end{array}$ \\
\hline & & & Ch. $15, \mathrm{li}^{\mathrm{v}}$ & $\begin{array}{l}\text { 'The amorous Roselia and Arbolinda heard all ioyously, but she } \\
\text { was more delighted, when the prince tooke a Lute and thus } \\
\text { expressed his loue passions...' }\end{array}$ \\
\hline 13 & $\begin{array}{l}\text { Marcos Martínez, trans. L.A., } \\
\text { The Seuenth Booke of the } \\
\text { Myrrour of Knighthood. } \\
\text { Being The Second of the } \\
\text { third Part. }\end{array}$ & $\begin{array}{l}\text { Thomas Purfoot, London, } \\
1598\end{array}$ & Ch. 2, E2 ${ }^{v}$ & $\begin{array}{l}\text { Don Eleno of Dacia '... tooke his Lute in hand, and making it } \\
\text { sound the repetition of his ioyes, he sung the felicitie that the } \\
\text { heauens gaue him in the possession of so rare a Lady } \\
\text { [=Rosamond]: in these verses ...' }\end{array}$ \\
\hline 14 & T. Tyro, Tyros Roring Megge & $\begin{array}{l}\text { Valentine Simmes, London, } \\
1598\end{array}$ & Decad 1, Epig. 5, $\mathrm{B}^{\vee}$ & $\begin{array}{l}\text { '.. Tyro can strike the sitterns siluer string, / And to the lute full } \\
\text { many a dittie sing ...' }\end{array}$ \\
\hline
\end{tabular}




\begin{tabular}{|c|c|c|c|c|}
\hline Doc. & Author / Title & Publisher / Year & Page / Folio & Passage / Comments \\
\hline 15 & $\begin{array}{l}\text { Henry Petowe, The Second } \\
\text { Part of Hero and Leander. }\end{array}$ & $\begin{array}{l}\text { Thomas Purfoot, London, } \\
1598\end{array}$ & $\mathrm{Bij}^{v}$ & $\begin{array}{c}\text { '... Apollo's Lute bereau'd of siluer string, / Fond Mercury doth } \\
\text { harshly gin to sing. / A counterfeit vnto his honney note ...' }\end{array}$ \\
\hline 16 & $\begin{array}{l}\text { Jorge de Montemayor, trans. } \\
\text { Bartholomew Yong, Diana } \\
\text { Of George Of Montemayor }\end{array}$ & Edm. Bollifant, London, 1598 & Pt 1, Bk 3, p. 429 & $\begin{array}{l}\text { 'For in that happie time, when Marcelius was a sutor to our sister } \\
\text { Alcida, he did some nights sing to the tune of his Lute so } \\
\text { sweetely, that if Orpheus made so solemne musicke, I did not } \\
\text { maruell then if the Birdes, and Beastes did follow him, and that } \\
\text { he brought backe his deere wife Euridice from darke hell.' }\end{array}$ \\
\hline 17 & $\begin{array}{l}\text { George Peele, The Love Of } \\
\text { King Dauid And Fair } \\
\text { Bethsabe. With the } \\
\text { Tragedie of Absalon }\end{array}$ & Adam Islip, London, 1599 & 'Prologus' (B'); and Diij” & $\begin{array}{l}\text { The 'Prologus' (sig. } B^{r} \text { ) speaks of David as 'Israels sweetest singer', } \\
\text { upon whose 'bosome of his yuorie Lute, / The Cherubins and } \\
\text { Angels laid their brests ...' In the play itself, David also says of } \\
\text { himself '... Let Dauids Harpe and Lute, his hand and voice, / } \\
\text { Giue laud to him that loueth Israel, / And sing his praise, that } \\
\text { shendeth Dauids fame ...' (sig.Diij"). }\end{array}$ \\
\hline \multirow[t]{3}{*}{18} & \multirow{3}{*}{$\begin{array}{l}\text { Alexander Hume, Hymnes, Or } \\
\text { Sacred Songs, wherein the } \\
\text { right vse of Poësie may be } \\
\text { espied }\end{array}$} & \multirow[t]{3}{*}{$\begin{array}{l}\text { Robert Walde-graue, } \\
\text { Edinburgh, } 1599\end{array}$} & $\begin{array}{l}\text { His Recantation. I, pp. 2-6 } \\
\text { (at p. 6) }\end{array}$ & $\begin{array}{l}\text { '... Euen on my iolie Lute, by night, / And trimling trible string, /, } \\
\text { I sall withall my minde and might, / Thy glorie gladlie sing ... }\end{array}$ \\
\hline & & & $\begin{array}{l}\text { Of Gods benefites bestowed } \\
\text { vpon man. II, pp. } 6-13 \\
\text { (at p. 13) }\end{array}$ & $\begin{array}{l}\text { '... But now my lips, and thou my Lute ming melodie amang / } \\
\text { Againe vnto the mightie God, go sing a newar sang.' }\end{array}$ \\
\hline & & & $\begin{array}{l}\text { The triumph of the Lord, after } \\
\text { the manner of men. VII., } \\
\text { pp. } 34-41 \text { (at p. } 40 \text { ) }\end{array}$ & $\begin{array}{l}\text { '... Nor Orpheus the craftie Thracian, / Phylirides, nor skilfull Arion, } \\
\text { / Nor famous lute of cunning Amphion, / Struike neuer note so } \\
\text { pleasant to the eir, / Nor sang sa sweit as they that sall be heir.' }\end{array}$ \\
\hline 19 & $\begin{array}{l}\text { William Shakespeare, The } \\
\text { Passionate Pilgrime }\end{array}$ & $\begin{array}{l}\text { [T. Judson for] W. laggard, } \\
\text { London, } 1599\end{array}$ & Poem 8, [B2] ${ }^{r}$ & $\begin{array}{l}\text { '... Dowland to thee is deere, whose heauenly tuch / Vpon the } \\
\text { Lute, dooth rauish humane sense: / Spenser to me, whose } \\
\text { deepe Conceit is such, / As passing all conceit, needs no } \\
\text { defence. / Thou lou'st to heare the sweet melodious sound, / } \\
\text { That Phoebus Lute (the Queene of Musicke) makes: / And I in } \\
\text { deepe Delight am chiefly drownd, / When as himselfe to singing } \\
\text { he betakes...' }\end{array}$ \\
\hline 20 & $\begin{array}{l}\text { Marcos Martínez, trans. L.A., } \\
\text { The Eighth Booke of the } \\
\text { Myrror of Knighthood. } \\
\text { Being the third of the third } \\
\text { Part. }\end{array}$ & $\begin{array}{l}\text { Thomas Creede, London, } \\
1599\end{array}$ & Ch. $27, \mathrm{Kk}^{\mathrm{r}}-\mathrm{Kk}^{\mathrm{v}}$ & $\begin{array}{l}\text { Agesilao, 'famoused to be an excellent Musitian', accepts a 'Lute } \\
\text { to play thereon' from 'his Lady' (Pollinarda) and then 'began to } \\
\text { touch it with more swéeter musicke then hee that descended to } \\
\text { the infernall Vaultes to fetch his wife. Then with a cleare voice } \\
\text { he warbled forth this Dittie ...' Agesilao is here described as }\end{array}$ \\
\hline
\end{tabular}




\begin{tabular}{|c|c|c|c|c|}
\hline Doc. & Author / Title & Publisher / Year & Page / Folio & Passage / Comments \\
\hline & & & & $\begin{array}{l}\text { having 'runne vpon the treble with such heauenly melodie' (n.b. } \\
\text { this refers to his lute playing). }\end{array}$ \\
\hline & & & Ch. $27, \mathrm{Kk}^{\mathrm{r}}$ & $\begin{array}{l}\text { Agesilao went with two men ' ... vnder his Ladies [=Pollinarda's] } \\
\text { window, where, knowing what pleasure she receiued with his } \\
\text { Musicke, he played this Dittie vppon his Lute ...' }\end{array}$ \\
\hline & & & Ch. $29, \mathrm{Mm}^{\mathrm{v}}$ & $\begin{array}{l}\text { Florisiano (from whose perspective the text is written) sings and } \\
\text { plays to his love interest Pollinarda: ' } \ldots \text { I tooke my Lute and } \\
\text { went to the window, where (not thinking because it was so late } \\
\text { any had heard me) I began to sing, and openly to expresse the } \\
\text { soueraigne ioy of my heart, in this maner ...' }\end{array}$ \\
\hline \multirow[t]{3}{*}{21} & \multirow{3}{*}{$\begin{array}{l}\text { Thomas Nash, } \text { A Pleasant } \\
\text { Comedie, called Summers } \\
\text { last will and Testament }\end{array}$} & \multirow[t]{3}{*}{ Simon Stafford, London, 1600} & $\mathrm{D} 2^{\mathrm{r}}$ & $\begin{array}{l}\text { Autumne says of Sol: 'He termes himselfe the god of Poetry, / And } \\
\text { setteth wanton songs vnto the Lute'. }\end{array}$ \\
\hline & & & \multirow[t]{2}{*}{$\mathrm{H}^{r}$} & $\begin{array}{l}\text { Summer asks to be entertained (it is slightly ambiguous who } \\
\text { Summer is speaking to, but only male characters are present) }\end{array}$ \\
\hline & & & & $\begin{array}{l}\text { 'To wearie out the time vntill they come, / Sing me some dolefull } \\
\text { ditty to the Lute, / That may complaine my neere approching } \\
\text { death.' }\end{array}$ \\
\hline 22 & $\begin{array}{l}\text { Robert Kittowe, Loues Load- } \\
\text { starre }\end{array}$ & Th. Creede, London, 1600 & {$[\mathrm{~B} 4]^{\mathrm{r}}$} & $\begin{array}{l}\text { '... Hauing thus contemplated with himselfe on the foresaid } \\
\text { accidents, to driue off that encreasing melancholy passion, he } \\
\text { [=Don Andrea Alizandra] tooke in hand his Lute, and thereon } \\
\text { recorded this Dittie ...' }\end{array}$ \\
\hline 23 & $\begin{array}{l}\text { Philip Rosseter and Thomas } \\
\text { Campion, } A \text { Booke Of Ayres }\end{array}$ & $\begin{array}{l}\text { Peter Short, Lonond }[\mathrm{sic}] \\
\quad 1601\end{array}$ & Bk 2, Song 8 & $\begin{array}{l}\text { '... They set the noat then tune the Lute, / harts frame their } \\
\text { thoughts then toongs their suit ...' }\end{array}$ \\
\hline \multirow[t]{2}{*}{24} & \multirow{2}{*}{$\begin{array}{l}\text { Battista Guarini, trans. John } \\
\text { Dymock (attrib.) and } \\
\text { Charles Dymock (attrib.), Il } \\
\text { Pastor Fido: Or The faithfull } \\
\text { Shepheard }\end{array}$} & \multirow[t]{2}{*}{$\begin{array}{l}\text { [Thomas Creede for] Simon } \\
\text { Waterson, London, } 1602\end{array}$} & \multirow[t]{2}{*}{$\begin{array}{l}\text { A Sonnet of the Translator, } \\
{[A]^{v}}\end{array}$} & $\begin{array}{l}\text { The phrase 'his tunes' in this context seems to imply singing, to } \\
\text { which 'Tassoes lute' joins: }\end{array}$ \\
\hline & & & & $\begin{array}{l}\text { 'A silly hand hath fashioned vp a sute / Of English clothes vnto a } \\
\text { traueller, / A noble minde though Shepheards weeds he weare, } \\
\text { / That might consort his tunes with Tassoes lute ...' }\end{array}$ \\
\hline
\end{tabular}




\begin{tabular}{|c|c|c|c|c|}
\hline Doc. & Author / Title & Publisher / Year & Page / Folio & Passage / Comments \\
\hline \multirow[t]{4}{*}{25} & \multirow{4}{*}{$\begin{array}{l}\text { Francis Davison, } \text { A Poetical } \\
\text { Rapsody Containing, } \\
\text { Diuerse Sonnets, Odes, } \\
\text { Elegies, Madrigalls, and } \\
\text { other Poesies }\end{array}$} & \multirow[t]{4}{*}{$\begin{array}{l}\text { V. S. [Valentine Simmes], } \\
\text { London, } 1602\end{array}$} & \multirow[t]{4}{*}{$14^{r}$} & $\begin{array}{l}\text { Three Odes translated out of Anacreon, the Greeke Lyrick Poet, } \\
\text { Ode I. }\end{array}$ \\
\hline & & & & $\begin{array}{l}\text { 'OF Atreus Sonnes faine would I write, / And faine of Cadmus } \\
\text { would I sing: / My Lute is set on Loues delight, / And onely } \\
\text { Loue sounds eu'ry string. Of late my Lute I alt'red quite, / } \\
\text { Both frets and strings for tunes aboue, / I sung of fierce Alcides } \\
\text { might, / My Lute would sound no tune but Loue, / Wherefore } \\
\text { yee worthles all farewell, / No tune but Loue my Lute can tell.' }\end{array}$ \\
\hline & & & & This text was reprinted twice during the period in question: \\
\hline & & & & $\begin{array}{l}\text { i) Francis Davison, A Poetical Rapsodie (1611), 157; and ii) Francis } \\
\text { Davison, Dauisons Poems, Or, A Poeticall Rapsodie (1621), Bk 4, } \\
248 \text { (XXVI. Ode) }\end{array}$ \\
\hline 26 & $\begin{array}{l}\text { Richard Knolles, The Generall } \\
\text { Historie of the Turkes }\end{array}$ & Adam Islip, London, 1603 & $776-7$ & $\begin{array}{l}\text { This recounts an occasion in Constantinople in the summer of } \\
\text { 1559, describing the Turkish forces, their way of life and their } \\
\text { discipline. The author fleetingly contrasts the Turks' lack of } \\
\text { drunkenness and card games with 'a rough Hungarian and his } \\
\text { companions' that he met, '... a souldior, who heauie himselfe, } \\
\text { to the Lute rather houled than sung a dolefull dittie, containing } \\
\text { the last words of a fellow of his, dying of his wounds vpon the } \\
\text { greene banke of Danubius...' }\end{array}$ \\
\hline 27 & $\begin{array}{l}\text { Henoch Clapham, Three } \\
\text { Partes of Salomon his Song } \\
\text { of Songs, expounded }\end{array}$ & Valentine Sims, London, 1603 & 156 (Lect. IIII) & $\begin{array}{l}\text { 'Ezekiel saith that the people in his time, did heare the Pro[p]hets } \\
\text { Lute, as songmen of pleasant voice: that is, did delight to heare, } \\
\text { but not to doe. Here the Church is called to doe according to } \\
\text { that they heare of these Apostolicall sweete singers of Israel: as } \\
\text { before did, and hereafter againe will appeare.' }\end{array}$ \\
\hline \multirow[t]{3}{*}{28} & \multirow[t]{3}{*}{$\begin{array}{l}\text { Anon., Englands vvelcome To } \\
\text { lames by the grace of God, } \\
\text { King of England, Scotland, } \\
\text { France and Ireland, } \\
\text { defender of the faith, \&c }\end{array}$} & \multirow[t]{3}{*}{ E. W. and C. K., London, 1603} & Canto I, $B^{r}-[B 4]^{r}\left(\right.$ at $\left.B 3^{v}\right)$ & $\begin{array}{l}\text { Written from an unknown male perspective; while 'modest } \\
\text { Muses', 'Graces', and 'frisking Fayries' sang and danced 'God } \\
\text { saue the King': ‘. . . Amongst the rest, I gladdest of the rest, / } \\
\text { Tun'd vp my Lute, and sung amongst the best.' }\end{array}$ \\
\hline & & & Canto II, [B4 $]^{v}-C 2^{r}\left(\right.$ at $\left.C^{r}-C^{v}\right)$ & The writer notes how he had: \\
\hline & & & & $\begin{array}{l}\text { '... carelesly had left vndone, / Those worthy praises, which I } \\
\text { ought t'haue done. / Vnto those worthyes, which proclaim'd my } \\
\text { King: / Then tooke my Lute, and thus againe did sing.' }\end{array}$ \\
\hline
\end{tabular}




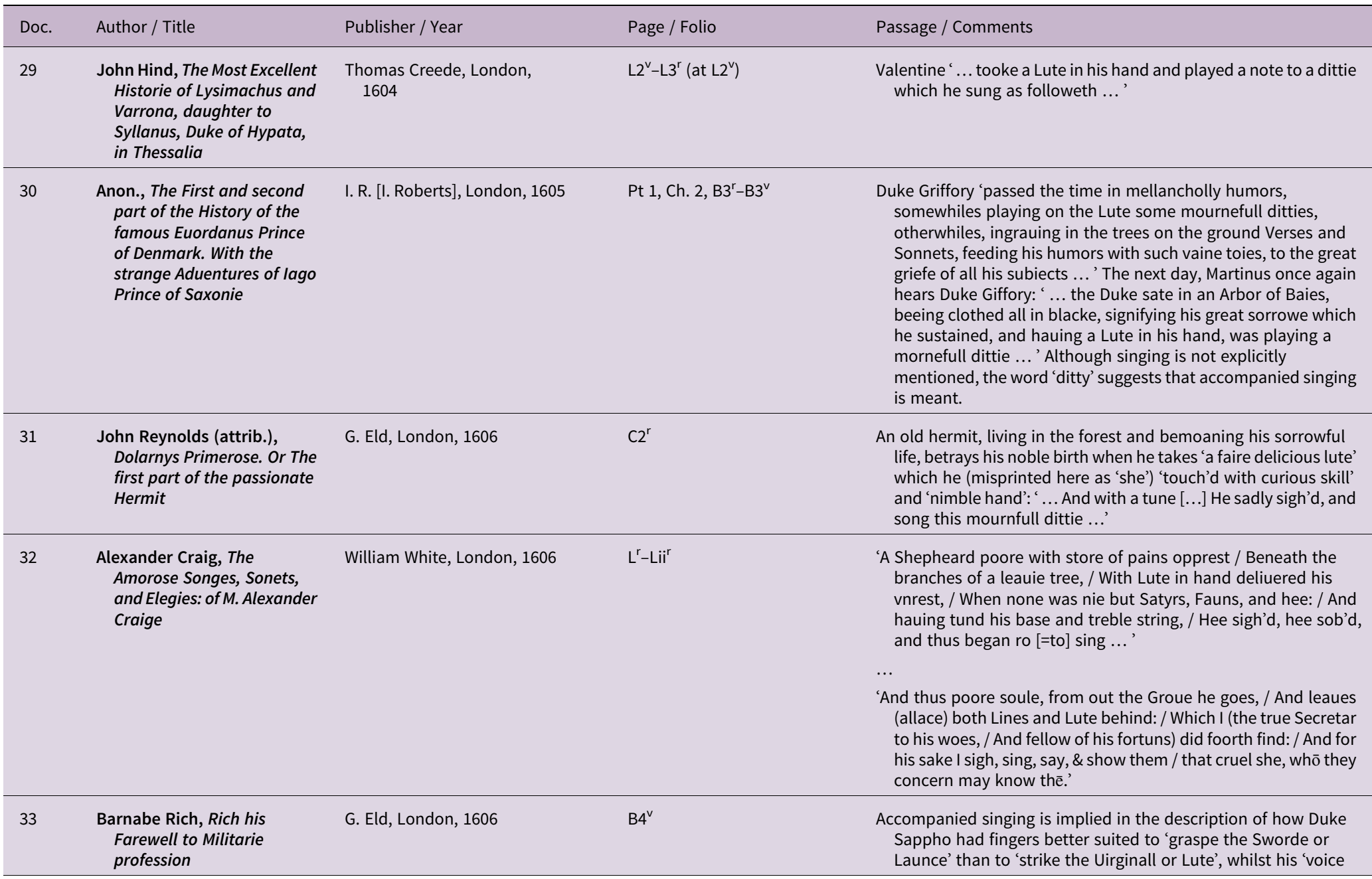




\begin{tabular}{|c|c|c|c|c|}
\hline Doc. & Author / Title & Publisher / Year & Page / Folio & Passage / Comments \\
\hline & & & & $\begin{array}{l}\text { serued him better to cheare his Souldiers in the fielde, then } \\
\text { either to faine or syng ditties in a Ladies Chamber. }\end{array}$ \\
\hline & & & D $3^{r}$ & $\begin{array}{l}\text { Sylvanus (= Duke Aurelianus in disguise, having been found in the } \\
\text { woods) writes verses in praise of his beloved Lady Valerya. He } \\
\text {... committed them to memory, and the next day, being in the } \\
\text { company of certaine Gentlemen \& Gentlewomen in the Court, } \\
\text { taking a Lute, whereon he could play very well, \& hauing } \\
\text { likewise good knowledge in his song, \& therewithall a very } \\
\text { pleasant voyce, he began to sing this ditty before mentioned ... } \\
\text { 'He stops singing when Valerya appears, but she asks him 'to } \\
\text { begin his song againe [...] and taking the Lute [Silvanus] began } \\
\text { his song ...' }\end{array}$ \\
\hline \multirow[t]{3}{*}{34} & $\begin{array}{l}\text { John Hind, Eliosto Libidinoso: } \\
\text { Described in two Bookes }\end{array}$ & $\begin{array}{l}\text { Valentine Simmes, London, } \\
\quad 1606\end{array}$ & [Bk 1], 43-6 (at 43) & $\begin{array}{l}\text { 'The Queene [...] requested him [=Eliosto], to contriue as } \\
\text { cunningly as he could, his fancie in a fiction, willing therefore to } \\
\text { shew his Mistresse (for such I must now tearme her) that he was } \\
\text { not ignorant in musicke, taking a Lute in his hand, began to } \\
\text { warble out this Roundelay ...' }\end{array}$ \\
\hline & & & Bk $2,77-8$ (at 77 ) & $\begin{array}{l}\text { Dihnohin, with 'a Lute in his hand [...] did in sad melodie sound } \\
\text { foorth his sorrowes' under the window of his beloved, } \\
\text { Gatesinea. Her nurse advises against offering her love too } \\
\text { easily, so Dihnohin comes oft to win her affections; he waits } \\
\text { until she appears '... then fingring his Lute, and framing his } \\
\text { voice, he vtter'd this passionate Dittie, making euery rest, a } \\
\text { deepe-fetched sigh ... }\end{array}$ \\
\hline & & & Bk 2, 91-3 (at 91) & $\begin{array}{l}\text { Eliosto '... taking a Lute in his hand, vpon a deep consideration of } \\
\text { his former follies, and present fortunes, hee sung this } \\
\text { Roundelay, which it seemes his dignitie had borrowed of a } \\
\text { worthy writer ...' }\end{array}$ \\
\hline 35 & $\begin{array}{l}\text { Henri Estienne, trans. } \\
\text { Richard Carew (attrib.), } \\
\text { A World of Wonders }\end{array}$ & $\begin{array}{l}\text { [Richard Field for] lohn } \\
\quad \text { Norton, London, } 1607\end{array}$ & $\begin{array}{l}\text { Pt 2, Bk 1, Ch. 37, pp. 291-301 } \\
\text { (at 298) }\end{array}$ & $\begin{array}{l}\text { Here, Estienne provides commentary on a French work entitled } \\
\text { Quadragesimale spirituale (printed in Paris, 1565), 'Chap. 19' } \\
\text { and 'Chap. 20' of which condemn those who turn to profane } \\
\text { pleasures instead of saying grace after eating; these include } \\
\text { one who 'takes a lute and playes wanton \& lasciuious songs, } \\
\text { toūds [=rounds], and horne pypes ...' }\end{array}$ \\
\hline
\end{tabular}




\begin{tabular}{|c|c|c|c|c|}
\hline Doc. & Author / Title & Publisher / Year & Page / Folio & Passage / Comments \\
\hline 36 & $\begin{array}{l}\text { Simon Goulart, trans. } \\
\text { Edward Grimeston, } \\
\text { Admirable and Memorable } \\
\text { Histories Containing the } \\
\text { wonders of our time }\end{array}$ & George Eld, London, 1607 & Resemblance, $527-30$ (at 529) & $\begin{array}{l}\text { Goulart here describes the remarkable similarities between a pair } \\
\text { of identical twins ('two Gentlemen Brethren') born in Avignon. } \\
\text { Amongst other things, they 'playde both of the Lute, Song their } \\
\text { parts' and the 'sound of their voyce' and 'actions were so like, as } \\
\text { their Father, Mother, and Brethren were deceiued to shewe the } \\
\text { difference'. }\end{array}$ \\
\hline 37 & John Marston, What Yov VVill & G. Eld, London, 1607 & $\begin{array}{l}\text { Act } 1 \text {, scene } i,[A 4]^{r}-B 3^{v} \text { (at } B^{r}- \\
\left.B^{v}\right)\end{array}$ & $\begin{array}{l}\text { lacomo says to Phylus (who earlier entered holding a lute, sig. } \\
{[\mathrm{A} 4]^{\mathrm{r}} \text { ): ' } . . . \text { And thou chanst bring Celias head out of the window }} \\
\text { with thy Lute, well hazard thy breath: looke Sir heares a ditty ... } \\
\text { 'The song follows along with the stage direction: 'Hee Singes } \\
\text { and is answered, from aboue a Willow garland is floung downe } \\
\text { and the songe ceaseth.' }\end{array}$ \\
\hline 38 & $\begin{array}{l}\text { John Day, Lavv-Trickes Or, } \\
\text { Who Wovld Have Thovght It }\end{array}$ & $\begin{array}{l}\text { [E. Allde for] Richard More, } \\
\text { London, } 1608\end{array}$ & Act $5,[G 4]^{r}-[14]^{r}\left(I^{r}-I^{v}\right)$ & $\begin{array}{l}\text { loculo (a page) proclaims 'I was taught to sing, / Vnto the Lute, and } \\
\text { Court each amorous string / With a soft finger' and then } \\
\text { confesses his age to be 'Eighteene' (he had thus presumably } \\
\text { gone through puberty by this age). }\end{array}$ \\
\hline 39 & $\begin{array}{l}\text { George Benson, } \text { A Sermon } \\
\text { Preached At Pavles Crosse } \\
\text { The Seaventh OfMay, M.DC. } \\
\text { IX. }\end{array}$ & $\begin{array}{l}\text { H. L. [Humfrey Lownes], } \\
\text { London, } 1609\end{array}$ & 76 & $\begin{array}{l}\text { Benson fleetingly refers to various cruel deeds of Roman Emperor } \\
\text { Nero, who 'plaied vpon his Lute and song verses of Homer, } \\
\text { concerning the burning of Troy, comparing the two Cities } \\
\text { together ... }\end{array}$ \\
\hline 40 & $\begin{array}{l}\text { Thomas Dekker, Foure Birds } \\
\text { Of Noahs Arke }\end{array}$ & $\begin{array}{l}\text { H. B. [H. Ballard], London, } \\
1609\end{array}$ & $\begin{array}{l}\text { Sec. } 1 \text {, no. } 8 \text { (A Prayer for a } \\
\text { Marriner at Sea in a } \\
\text { storme), 28-31 (at 31) }\end{array}$ & $\begin{array}{l}\text { '... Saue vs, O saue vs, for thine owne sake, for thy Sonnes Sake, } \\
\text { for thy glories sake, and wee shall sing Psalmes in thy praises } \\
\text { vpon the lute, and vpon an instrument of ten strings.' }\end{array}$ \\
\hline \multirow[t]{2}{*}{41} & \multirow[t]{2}{*}{$\begin{array}{l}\text { Nicolas de Montreux, trans. } \\
\text { Robert Tofte, Honovrs } \\
\text { Academie. Or The Famovs } \\
\text { Pastorall, of the faire } \\
\text { Shepheardesse, Ivlietta. }\end{array}$} & \multirow[t]{2}{*}{$\begin{array}{l}\text { Thomas Creede, London, } \\
1610\end{array}$} & $72-3$ (at 72) & $\begin{array}{l}\text { Alfonso '... called his sad Page vnto him, who, being commanded } \\
\text { by him, tooke his Lute in his hand, and with an excellent sweet } \\
\text { voyce, vnto a most dolefull tune, sung these verses following, } \\
\text { before his weeping Mistris [=lustina] ...' }\end{array}$ \\
\hline & & & $161-2$ (at 161) & $\begin{array}{l}\text { Don lohn ' ... called for pen and Inke, and thereupon composed } \\
\text { these sad verses following, which he would oftentimes sing } \\
\text { vnto his Lute.' }\end{array}$ \\
\hline 42 & $\begin{array}{l}\text { Joannes Boemus, trans. } \\
\text { Edward Aston, The } \\
\text { Manners, Lauues, And } \\
\text { Cvstomes Of All Nations. }\end{array}$ & G. Eld, London, 1611 & Bk 3, Ch.21, p. 357 & $\begin{array}{l}\text { The Galatians ' ... haue a certaine manner of Poets or Musitions } \\
\text { which they call (Bardi) that sing vnto Organs and winde } \\
\text { Instruments, as others doe to the Harp or Lute, praysing some } \\
\text { in their songs and sonnets and dispraysing others ...' Although } \\
\text { this describes musicians in Anatolia (in modern Turkey), }\end{array}$ \\
\hline
\end{tabular}




\begin{tabular}{|c|c|c|c|c|}
\hline Doc. & Author / Title & Publisher / Year & Page / Folio & Passage / Comments \\
\hline & & & & $\begin{array}{l}\text { Edward Aston has clearly used terminology from contemporary } \\
\text { English music-making in his translation. }\end{array}$ \\
\hline 43 & $\begin{array}{l}\text { Richard Brathwaite, The } \\
\text { Golden Fleece. Whereto } \\
\text { bee annexed two Elegies }\end{array}$ & $\begin{array}{l}\text { W. S. [William Stansby], } \\
\text { London, } 1611\end{array}$ & $\begin{array}{l}\text { Sonnets or Madrigals; } \\
\text { The Epistle Dedicatorie, } E 4^{r}- \\
{[E 7]^{r}\left(\text { at }[E 6]^{v}\right)}\end{array}$ & $\begin{array}{l}\text { '... Terpnus, who was Neroes musitian, was out of his element } \\
\text { when he had not a Lute in his hand, and a wanton song before } \\
\text { him ...' }\end{array}$ \\
\hline \multirow[t]{9}{*}{44} & \multirow[t]{9}{*}{$\begin{array}{l}\text { Guillaume de Salluste Du } \\
\text { Bartas, trans. Josuah } \\
\text { Sylvester, Du Bartas His } \\
\text { Deuine Weekes and Workes } \\
\text { Translated }\end{array}$} & \multirow[t]{9}{*}{$\begin{array}{l}\text { Humfrey Lounes, London, } \\
1611\end{array}$} & $290-1$ & $\begin{array}{l}\text { This tells the story of how lubal creates a 'melodious Lute' out of } \\
\text { an 'open Tortoise lying on the ground' that makes 'woods } \\
\text { harken' and 'windes be mute', amongst other things. lubal is } \\
\text { then described singing to it: }\end{array}$ \\
\hline & & & & $\begin{array}{l}\text { '... His Art, still waxing, sweetly marrieth / His quavering fingers to } \\
\text { his warbling breath: / More little tongues to's charm-care Lute } \\
\text { he brings ...' }\end{array}$ \\
\hline & & & 399 & $\begin{array}{l}\text { The words 'lays' and 'song' suggest that the soldier sings and plays } \\
\text { at the same time, hence why it is included here; accompanied } \\
\text { song is not explicitly described, however, and the passage may } \\
\text { instead relate simply to instrumental music: }\end{array}$ \\
\hline & & & & $\begin{array}{l}\text { '... Another [=one of the Hebrew soldiers], while ingeniously he } \\
\text { plays / Vpon his Lute som passing-pleasing Lays, / Sleep sieles } \\
\text { his eyes vp with a gloomy clowd; / And yet his hand still quauers } \\
\text { light and lowd: / But, at the last it sinks; and, offring fair / To } \\
\text { strike the Base, strikes but the empty ayr: / His soule, } \\
\text { descending to th' Infernall Coasts, / Goes to conclude his Song } \\
\text { vnto the Ghosts...' }\end{array}$ \\
\hline & & & $811-12$ & $\begin{array}{l}\text { It is not clear if the singing is just to the virginals, or also to the } \\
\text { lute, hence why it is included here; the passage as a whole is } \\
\text { clearly written from a male perspective. }\end{array}$ \\
\hline & & & & '... One while vpon the Lute, my nimbleioints I plie, \\
\hline & & & & Then on the Virginalls: to whose sweet harmonie \\
\hline & & & & Marrying my simple voice, in solemne Tunes I sing \\
\hline & & & & Some Psalme or holy Song, vnto the heauenly King ...' \\
\hline 45 & $\begin{array}{l}\text { Richard Hooker, } \text { A Learned } \\
\text { And Comfortable Sermon }\end{array}$ & loseph Barnes, Oxford, 1612 & 14 & $\begin{array}{l}\text { On people comparing themselves to others and thus judging God } \\
\text { and his works erroneously through man's actions (it is implicit }\end{array}$ \\
\hline
\end{tabular}




\begin{tabular}{|c|c|c|c|c|}
\hline Doc. & Author / Title & Publisher / Year & Page / Folio & Passage / Comments \\
\hline & $\begin{array}{l}\text { Of The certaintie and } \\
\text { perpetuitie of faith in the } \\
\text { Elect }\end{array}$ & & & $\begin{array}{l}\text { that 'they' includes men): ' } \ldots \text { they sing to the lute, and they see } \\
\text { their children dance before them ...' This reference is also cited } \\
\text { in Bartholomew Robertson, Spiritvall Encrease (1621), } 166 .\end{array}$ \\
\hline 46 & $\begin{array}{c}\text { Francis Rollenson, Twelve } \\
\text { Prophetical Legacies }\end{array}$ & $\begin{array}{l}\text { T. C. [Thomas Creede], } \\
\text { London, } 1612\end{array}$ & $92-113$ (at 109) & $\begin{array}{l}\text { '... Many that are Rich, wil not call vpon their Lutes \& Harps, as } \\
\text { Dauid did, saying, Awake Lute and Harpe, singing vnto them this } \\
\text { Ditie, (Psal.30.I) I will magnifie thee O Lorde, for thou hast } \\
\text { exalted me; but they attribute the increase of their wealth to } \\
\text { their owne pollicie and indeuour...' }\end{array}$ \\
\hline 47 & $\begin{array}{l}\text { Jean Bertaut, trans. Josuah } \\
\text { Sylvester, The Parliament } \\
\text { of Vertues Royal }\end{array}$ & $\begin{array}{l}\text { Humphrey Lownes, London, } \\
1614\end{array}$ & $\mathrm{Bk} 3,120$ & $\begin{array}{l}\text { This describes the appearance and characteristics of a wealthy } \\
\text { 'Persian... proud of th'Imperiall state', whose 'too sumptuous } \\
\text { Suits; / His painted Cheeks, his Phrygik Layes \& Lutes' (amongst } \\
\text { other things) did not 'smock' his 'Manly mind'. Although a } \\
\text { description of foreign music-making, the terminology used } \\
\text { clearly reflects that used in contemporary English. }\end{array}$ \\
\hline \multirow[t]{2}{*}{48} & \multirow{2}{*}{$\begin{array}{l}\text { Luis Hurtado (attrib.), trans. } \\
\text { Anthony Munday, The } \\
\text { [First-] Second Part Of The } \\
\text { No Lesse Rare, Then } \\
\text { Excellent And stately } \\
\text { Historie, of the famous, and } \\
\text { fortunate Prince Palmerin } \\
\text { of England and Florian de } \\
\text { Desart his brother }\end{array}$} & \multirow[t]{2}{*}{$\begin{array}{l}\text { Thomas Creede and Bernard } \\
\text { Alsop, London, } 1616\end{array}$} & Pt 1 , ch. $18,[\mathrm{~F} 6]^{v}$ & $\begin{array}{l}\text { Palmerin enters the castle and is enticed to enter by doleful music } \\
\text { he hears, which is played by 'one sitting all in blacke, with a fair } \\
\text { long Beard, and a very graue countenance'. Palmerin stops and } \\
\text { listens to the man '... singing many sadde Dittyes to his Lute, } \\
\text { that himselfe had framed, in the prayse of his Ladie ...' }\end{array}$ \\
\hline & & & Pt 1 , ch. $19,[\mathrm{~F} 8]^{\mathrm{v}}$ & $\begin{array}{l}\text { Floraman, having joined the Turks against his own father (the } \\
\text { King of Sardinia) due to the poisoning of his beloved Altea, } \\
\text { regularly sings 'her praise, and his owne paine' to her portrait in } \\
\text { 'sundry Lamentable Sonnets [...] which to his Lute hee often } \\
\text { recorded'. }\end{array}$ \\
\hline 49 & $\begin{array}{l}\text { Robert Greene, Alcida } \\
\quad \text { Greenes Metamorphosis }\end{array}$ & $\begin{array}{l}\text { George Purslowe, London, } \\
1617\end{array}$ & $12^{v}-13^{r}\left(\right.$ at $\left.12^{v}\right)$ & $\begin{array}{l}\text { Marpesia and one of her gentlewomen hears Eurymachus with } \\
\text { 'his Lute in his hand, playing certaine melancholy dumpes... } \\
\text { sing to his Lute this mornefull madrigall ...' }\end{array}$ \\
\hline 50 & $\begin{array}{l}\text { Robert Greene, rev. Dunstan } \\
\text { Gale, The History Of } \\
\text { Arbasto King of Denmarke }\end{array}$ & I. B [I. Beale], London, 1617 & Ch. 1 , pp. 3-4 (at 3) & $\begin{array}{l}\text { An old priest took 'his Lute, plaied a dumpe, whereto he warbled } \\
\text { out these words: ...' This is a reprint of Robert Greene, Arbasto } \\
\text { (1589), sig.A.iii' -sig.A.iiiir. }\end{array}$ \\
\hline 51 & $\begin{array}{l}\text { William Drummond, Forth } \\
\text { Feasting. A Panegyricke To }\end{array}$ & Andro Hart, Edinburgh, 1617 & $\mathrm{~A} 4^{\mathrm{v}}$ & This poem is addressed to James I of England and VI of Scotland: \\
\hline
\end{tabular}




\section{Continued}

\begin{tabular}{|c|c|c|c|c|}
\hline Doc. & Author / Title & Publisher / Year & Page / Folio & Passage / Comments \\
\hline & $\begin{array}{l}\text { The Kings Most Excellent } \\
\text { Maiestie }\end{array}$ & & & 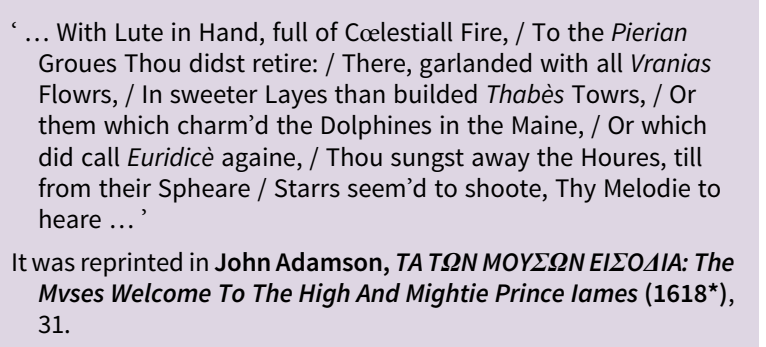 \\
\hline 52 & $\begin{array}{l}\text { John Moore, A Mappe Of Mans } \\
\text { Mortalitie }\end{array}$ & $\begin{array}{l}\text { T. S. [Thomas Snodham], } \\
\text { London, } 1617\end{array}$ & Bk 2, Ch. 7, p. 145 , no. 6 & $\begin{array}{l}\text { Accompanied singing may be implied here in relation to the lute } \\
\text { and harp: } \\
\text { '... let vs learne of the Musitian, who (according to the songs that } \\
\text { he singeth, or playeth, vpon the Lute, Harpe or Recorder) hath } \\
\text { his countenance and passions accordingly framed and affected } \\
\text {...' }\end{array}$ \\
\hline 53 & $\begin{array}{l}\text { Thomas Campion, The Third } \\
\text { And Fovrth Booke Of Ayres }\end{array}$ & $\begin{array}{l}\text { Thomas Snodham, London, } c \text {. } \\
1618\end{array}$ & $\begin{array}{l}\text { Bk } 4 \text { (=“The Second Booke”), } \\
\text { song } 8, \mathrm{H} 2^{\mathrm{v}}\end{array}$ & 'To his sweet Lute Apollo sung the motions of the Spheares ...' \\
\hline 54 & $\begin{array}{l}\text { George Chapman, Tvvo VVise } \\
\text { Men And All The Rest Fooles }\end{array}$ & S. n., London, 1619 & Act 6 , sc. i, $\mathrm{K} 2^{r}$ & $\begin{array}{l}\text { Furioso (a soldier): } \\
\text { '... It is not long since you were teaching the lute to a pretie wench } \\
\text { and wittie, and were fingring her frets vnfit for your dittie ...' }\end{array}$ \\
\hline 55 & $\begin{array}{l}\text { Henry Hutton, Follie's } \\
\text { Anatomie }\end{array}$ & $\begin{array}{l}\text { [Nicholas Okes for] Mathew } \\
\text { Walbanke, London, } 1619\end{array}$ & $\mathrm{D} 3^{\mathrm{r}}-\mathrm{E} 3^{\mathrm{v}}$ (at $[\mathrm{D} 5]^{\mathrm{r}}$ ) & $\begin{array}{l}\text { '... mi[g]hty loue, with Orpheus sweetest hymns, / Aptly } \\
\text { concording to Arions Lute ...' }\end{array}$ \\
\hline 56 & $\begin{array}{l}\text { Virgil, trans. John Brinsley, } \\
\text { Virgils Eclogues, With His } \\
\text { Booke De Apibus }\end{array}$ & Richard Field, London, 1620 & Georgicks: Bk 4, p. 154, Col. 1 & $\begin{array}{l}\text { 'But yet how Orpheus / himselfe though excee- / dingly bewailing his } \\
\text { / deare wife, yet labored / to asswage his sorowful / loue with } \\
\text { doleful songs / \& with his hollow lute.' } \\
\text { (Column } 3 \text { on the same page has a slightly embellished variant of } \\
\text { the same passage.) }\end{array}$ \\
\hline
\end{tabular}




\begin{tabular}{|c|c|c|c|c|}
\hline Doc. & Author / Title & Publisher / Year & Page / Folio & Passage / Comments \\
\hline \multirow[t]{2}{*}{57} & \multirow[t]{2}{*}{$\begin{array}{l}\text { Giovanni Boccaccio, trans. } \\
\text { John Florio (attrib.), The } \\
\text { Decameron Containing An } \\
\text { hundred pleasant Nouels }\end{array}$} & \multirow[t]{2}{*}{ Isaac lagard, London, 1620} & \multirow[t]{2}{*}{$\begin{array}{l}\text { The Tenth and last Day: The } \\
\text { Seuenth Nouell, } 158^{v}-163^{r} \\
\left(\text { at } 159^{v}-161^{r} \text { ) }\right.\end{array}$} & $\begin{array}{l}\text { Bernardo Puccino (a Florentine apothecary) sends for Manutio, } \\
\text { 'a most excellent Musitian, both for his voyce in singing, } \\
\text { and exquisite skill in playing on Instruments', to comfort } \\
\text { his daughter Lisana. He '... played dexteriously on his Lute, } \\
\text { which purposely hee had brought with him, and likewise he } \\
\text { sung diuers excellent Ditties ...' }\end{array}$ \\
\hline & & & & $\begin{array}{l}\text { Manutio subsequently sings a song in honour of the lovesick } \\
\text { Lisana to King Piero, with a 'dittie' written by 'one of the best } \\
\text { Poets in the composing of verses'. King Piero commands } \\
\text { Manutio, who has matched the text 'with noates so moouing } \\
\text { and singularly musicall', to 'vse both his Lute and voyce'. After } \\
\text { this, Manutio returns to Lisana, 'taking his Lute also with him', } \\
\text { where he 'sung the song to her, in as excellent manner as he } \\
\text { had done before', thus helping to cure Lisana of her } \\
\text { lovesickness. }\end{array}$ \\
\hline \multirow[t]{2}{*}{58} & \multirow[t]{2}{*}{$\begin{array}{l}\text { Francis Beaumont and John } \\
\text { Fletcher, Phylaster. Or, } \\
\text { Loue lyes a Bleeding }\end{array}$} & \multirow[t]{2}{*}{$\begin{array}{l}\text { Thomas Walkley, London, } \\
\qquad 1620\end{array}$} & \multirow[t]{2}{*}{$\begin{array}{l}\text { Act } 3 \text {, sc. i, pp. 27-39, } \\
\quad \text { (at 35-37) }\end{array}$} & $\begin{array}{l}\text { The 'Princesse' is dismayed when the King instructs her to } \\
\text { remove from service ('put away') her page boy Bellario, who } \\
\text { 'sings, and plaies' and is assumed to be 'about eighteene'. } \\
\text { When Philaster, her love interest, advises her to follow the } \\
\text { King's instruction, she replies: }\end{array}$ \\
\hline & & & & $\begin{array}{l}\text { 'O cruell, are you hard hearted too? / Who shall now tell you how } \\
\text { much I loued you? / Who shall sweare it to you, and weepe the } \\
\text { teares I send? / Who shall now bring you letters, rings, braslets, / } \\
\text { Loose his health in seruice, make tedious nights, / In stories of } \\
\text { your praise? Who shall now sing / Your crying Elegies, and strike } \\
\text { a sad soule / Into senselesse pictures, and make them warme? / } \\
\text { Who shall take vp his lute, and touch it, / Till he crowne a silent } \\
\text { sleepe vpon my eye-lids, Make me dreame and crie: / O my } \\
\text { deere, deere Phylaster.' }\end{array}$ \\
\hline \multirow[t]{3}{*}{59} & \multirow{3}{*}{$\begin{array}{l}\text { Miguel de Cervantes } \\
\text { Saavedra, trans. Thomas } \\
\text { Shelton, The Second Part } \\
\text { Of The History Of The } \\
\text { Valorous and witty Knight- } \\
\text { Errant, Don Quixote of the } \\
\text { Mançha }\end{array}$} & \multirow{3}{*}{$\begin{array}{l}\text { [Eliot's Court Press for] } \\
\text { Edward Blount, London, } \\
1620\end{array}$} & \multirow[t]{2}{*}{ Ch. 12 , pp. $69-74$ (at $72-3$ ) } & $\begin{array}{l}\text { A lovesick 'Knight of the Wood' is overheard by Don Quixote and } \\
\text { Sancho: }\end{array}$ \\
\hline & & & & $\begin{array}{l}\text { 'But harke, it seemes he [=the 'Knight of the Wood'] is tuning a } \\
\text { Lute, or Viall, and by his spitting and cleering his brest, he } \\
\text { prepares himselfe to sing [...] and whil'st the two [=Sancho and } \\
\text { Don Quixote] were astonisht, he sung as followeth ...' }\end{array}$ \\
\hline & & & Ch. 46 , pp. $300-5$ (at $301-3$ ) & $\begin{array}{l}\text { Don Quixote requests 'a Lute into my Chamber soone at night' to } \\
\text { comfort Altisidora, an 'afflicted Damozell'. His request is }\end{array}$ \\
\hline
\end{tabular}




\begin{tabular}{|c|c|c|c|c|}
\hline Doc. & Author / Title & Publisher / Year & Page / Folio & Passage / Comments \\
\hline & & & & $\begin{array}{l}\text { fulfilled, although the instrument is then described as 'a Vyoll', } \\
\text { which after 'ordering it as well as he could, he spit and cleared } \\
\text { his brest, and straight vvith a voyce somewhat hoarceish, } \\
\text { though tuneable, he sung the ensuing Romant, which the same } \\
\text { day he had composed...' The confusion regarding what } \\
\text { instrument is used reflects the original text, which first refers to } \\
\text { a 'laúd', then a 'vihuela'. Although 'vihuela' initially indicated all } \\
\text { figure-of-eight shaped string instruments (bowed and } \\
\text { plucked), it generally means the popular guitar-like instrument; } \\
\text { Shelton may have been unfamiliar with it, hence his (mis) } \\
\text { translation 'Vyoll'. This also surely explains the passage in } \\
\text { Chapter XII ('a Lute, or Viall'). }\end{array}$ \\
\hline \multirow[t]{2}{*}{60} & \multirow[t]{2}{*}{$\begin{array}{l}\text { Richard Brathwaite, Natvres } \\
\text { Embassie: Or, The Wilde- } \\
\text { Mans Measvres }\end{array}$} & \multirow[t]{2}{*}{$\begin{array}{l}\text { Richard Whitaker, London, } \\
\quad 1621\end{array}$} & \multirow[t]{2}{*}{$\begin{array}{l}\text { Sec. 2, The Eighth Satyre, } \\
119-27 \text { (at 119) }\end{array}$} & $\begin{array}{l}\text { 'Terpnus Musician to a tyrant Prince, / Nero by name, did in } \\
\text { the funeralls / Which were solemniz'd on his mothers hearse, / } \\
\text { Sing on his Lute these wofull tragicalls: ...' }\end{array}$ \\
\hline & & & & $\begin{array}{l}\text { Later on (page 122), Nero requests Terpnus to 'Sing to thy Lute... } \\
\text { straines of delight.' Incidentally, a few strophes later, Terpnus is } \\
\text { then described as playing a 'lyre' (page 123). }\end{array}$ \\
\hline 61 & $\begin{array}{l}\text { Lope de Vega, trans. William } \\
\text { Dutton (attrib.), The } \\
\text { Pilgrime Of Casteele }\end{array}$ & $\begin{array}{l}\text { [E. Allde for] John Norton, } \\
\text { London, } 1621\end{array}$ & Bk 4, pp. $100-50$ (at 134) & $\begin{array}{l}\text { Thesander' . . taking the Lute from Nisa, answered her with these } \\
\text { Verses, which hee had conceiued in his minde the night before } \\
\text {... }\end{array}$ \\
\hline \multirow[t]{2}{*}{62} & \multirow{2}{*}{$\begin{array}{l}\text { William Slatyer, The History } \\
\text { Of Great Britanie from the } \\
\text { first peopling of this I[s] } \\
\text { land to this present Raigne }\end{array}$} & \multirow[t]{2}{*}{ W. Stansby, London, [1621] } & $\begin{array}{l}\text { Palae Albion, Ode 1: Canz.4, } \\
\text { pp. } 10-11 \text { (at 11) }\end{array}$ & '... faire Sol, at my sute, / Shalt sing them to thy Ebon Lute.' \\
\hline & & & $\begin{array}{l}\text { Palae Albion, Ode 1: Canz.10, } \\
\text { pp. 16-19 (at 19) }\end{array}$ & $\begin{array}{l}\text { '... Like Orpheus with his daintie Lute, / The Woods, Fields, } \\
\text { Flouds, and Fishes mute, / He held attentiue, and among, / The } \\
\text { sauage Beasts with his sweet song ...' }\end{array}$ \\
\hline 63 & $\begin{array}{l}\text { Lady Mary Wroth, The } \\
\text { Countesse of } \\
\text { Mountgomeries Urania }\end{array}$ & $\begin{array}{l}\text { [?Augustine Mathews for] } \\
\text { loh[n] Marriott and lohn } \\
\text { Grismand, London, } 1621\end{array}$ & Bk 1 , at $53-5$ & $\begin{array}{l}\text { Amphilanthus, leaving behind his beloved Antissia, journeys to } \\
\text { Italy and alights in a virtually uninhabited place where he takes } \\
\text { refuge in a wood; whilst reflecting on his situation, he hears 'a } \\
\text { delicate (yet dolefull) voyce, a Lute finely plaid vpon, giuing } \\
\text { musicke to his Song ...' The unnamed voice acts as a mirror of } \\
\text { Amphilanthus's thoughts and is 'perceiued' by Amphilanthus to } \\
\text { be that of a 'young man'. This young man then passes } \\
\text { Amphilanthus towards the river and 'his Lute he held in his }\end{array}$ \\
\hline
\end{tabular}




\begin{tabular}{|c|c|c|c|c|}
\hline Doc. & Author / Title & Publisher / Year & Page / Folio & Passage / Comments \\
\hline & & & & $\begin{array}{l}\text { hand, till againe hauing some more Verses fram'd in his minde } \\
\text { (perfect louers neuer wanting inuention) he againe played, and } \\
\text { sung ... }\end{array}$ \\
\hline & & & Bk 4 , at $510-11$ & $\begin{array}{l}\text { The 'Duke of Wertenberg' (=Wartenberg) 'admirably [...] played } \\
\text { on the Lute' and hid himself under his lover's window 'going, } \\
\text { playing, and singing' and 'spake in great passion these words ... }\end{array}$ \\
\hline 64 & $\begin{array}{l}\text { Robert Burton, The Anatomy } \\
\text { Of Melancholy, What it Is }\end{array}$ & $\begin{array}{l}\text { Iohn Lichfield and lames } \\
\text { Short, Oxford, } 1621\end{array}$ & $\begin{array}{l}\text { Part } 1 \text {, Sec. 2, Memb. } 4 \text {, } \\
\quad \text { Svbsect. } 4, N 3^{v}-[N 5]^{r} \text {, at } N 4^{r}\end{array}$ & $\begin{array}{l}\text { Citing lovius, Burton discusses 'silly fellowes' via the example of } \\
\text { the 'musitian' Tarascomus of Parma: because '... he thought } \\
\text { himself to be a man of most excellent skill, (who was indeed a } \\
\text { ninny) they [=Leo Decimus and Bibiena] made him set foolish } \\
\text { songs, and invent new ridiculous precepts, which they did highly } \\
\text { commend, as to tye his arme that plaid on the lute, to make him } \\
\text { strike a sweeter stroke, and to pull downe the Arras hangings, } \\
\text { because the voice would be clearer, by reason of the } \\
\text { reverberation of the wall.' }\end{array}$ \\
\hline 65 & $\begin{array}{l}\text { Horace, trans. John } \\
\text { Ashmore, Certain Selected } \\
\text { Odes Of Horace, Englished }\end{array}$ & $\begin{array}{l}\text { H. L. [Humfrey Lownes], } \\
\text { London, } 1621\end{array}$ & Lib. 3. Ode 30 , p. 28 & $\begin{array}{l}\text { '... And poor in water where old Daunus forth doth showe / His } \\
\text { sun-burnt face to people rude, that I (from lowe / Estate } \\
\text { advanc't) was he that first of all did suit / Aeolian Songs and } \\
\text { Sonnets to a Roman Lute ...' }\end{array}$ \\
\hline 66 & $\begin{array}{l}\text { Gonzalo de Céspedes y } \\
\text { Meneses, trans. Leonard } \\
\text { Digges, Gerardo The } \\
\text { Vnfortunate Spaniard. Or A } \\
\text { Patterne For Lasciviovs } \\
\text { Lovers }\end{array}$ & $\begin{array}{l}\text { [George Purslowe for] Ed. } \\
\text { Blount, London, } 1622\end{array}$ & Pt 1, Disc. 1, pp. 9-11 (at 9) & $\begin{array}{l}\text { Gerardo '... falling into his sad Dumpes, and willing to beguile his } \\
\text { fancy, he called for a Lute, (which cunningly tuned) with a } \\
\text { cleere Voice and pleasing Dittie he mustered vp his lifes former } \\
\text { passages, in the insuing Verses ...' }\end{array}$ \\
\hline \multirow[t]{3}{*}{67} & $\begin{array}{l}\text { George Wither, Faire-Virtve, } \\
\text { The Mistresse Of Phil'arete }\end{array}$ & $\begin{array}{l}\text { [Augustine Mathews for] John } \\
\text { Grismand, London, } 1622\end{array}$ & $K 3^{r}-[K 6]^{r}\left(\right.$ at $\left.K 3^{r}\right)$ & $\begin{array}{l}\text { The nymphs secretly listen to Philarete (described on sig.B3r as 'a } \\
\text { Shepheards lad...obscure and young', i.e. a mature youth) } \\
\text { singing to his 'Lute', who comes 'day by day, / In these Groues to } \\
\text { sing, and play'. They are careful not to disturb him, for 'mute / } \\
\text { Will his Tougne be, and his Lute' if he notices 'vnlookt for } \\
\text { Company'. }\end{array}$ \\
\hline & & & $M 3^{v}-[M 8]^{r}\left(\right.$ at $\left.M 3^{v}\right)$ & $\begin{array}{l}\text { Philarete '... taking downe a Lute, that neere him hung, / He } \\
\text { gaue't his Boy, who plaid; whilst this, he sung ... }\end{array}$ \\
\hline & & & & $\begin{array}{l}\text { Afterwards, on sig.[M5] }]^{\mathrm{v}} \text {, the shepherd is subsequently asked to } \\
\text { sing one more song, 'which request, he instantly obaid; / And, } \\
\text { this ensuing Song, both sung and plaid ...' }\end{array}$ \\
\hline
\end{tabular}




\begin{tabular}{|c|c|c|c|c|}
\hline Doc. & Author / Title & Publisher / Year & Page / Folio & Passage / Comments \\
\hline \multirow[t]{2}{*}{68} & $\begin{array}{l}\text { Henry Peacham, The } \\
\text { Compleat Gentleman }\end{array}$ & $\begin{array}{l}\text { [John Legat for] Francis } \\
\text { Constable, London, } 1622\end{array}$ & Ch. 11 , pp. $96-104$ (at 100) & $\begin{array}{l}\text { This passage-clearly addressed to a courtly male reader-may } \\
\text { imply accompanied singing to lute or viol: }\end{array}$ \\
\hline & & & & $\begin{array}{l}\text { 'I desire no more in you then to sing your part sure, and at the first } \\
\text { sight, withall, to play the same vpon your Violl, or the exercise of } \\
\text { the Lute, priuately to your selfe.' }\end{array}$ \\
\hline \multirow[t]{2}{*}{69} & $\begin{array}{l}\text { William Shakespeare, ed. } \\
\text { John Heminge and Henry }\end{array}$ & $\begin{array}{l}\text { Isaac laggard and Ed. Blount, } \\
\text { London, } 1623\end{array}$ & $\begin{array}{l}\text { The Famous History of the Life } \\
\text { of King Henry the Eight, Act }\end{array}$ & $\begin{array}{l}\text { The scene opens with Queen Katherine asking one of her women } \\
\text { to sing to her lute; her song begins: }\end{array}$ \\
\hline & $\begin{array}{l}\text { Condell, } M^{r} \text {. VVilliam } \\
\text { Shakespeares Comedies, } \\
\text { Histories, \& Tragedies. }\end{array}$ & & 3, sc. i, pp. 218-19 (at 218) & $\begin{array}{l}\text { 'ORpheus with his Lute made Trees, / And the Mountaine tops that } \\
\text { freeze, / Bow themselues when he did sing ...' }\end{array}$ \\
\hline \multirow[t]{7}{*}{70} & $\begin{array}{l}\text { Homer, trans. George } \\
\text { Chapman, the Crowne of } \\
\text { all Homers Workes }\end{array}$ & Iohn Bill, London, ?1624 & $\begin{array}{l}\text { A Hymne to Hermes, } 51-87 \text { (at } \\
53-5 \text { and } 77-83 \text { ) }\end{array}$ & $\begin{array}{l}\text { This lengthy hymn to Hermes tells the story of the god's birth } \\
\text { and childhood. It tells how Hermes makes a lute out of a } \\
\text { 'Tortois' with 'Seuen strings, of seuerall tunes [...] Made of the } \\
\text { Entrailes of a sheepe well dried'; when it was finished, he } \\
\text { accompanied himself on it (p. 55): }\end{array}$ \\
\hline & & & & $\begin{array}{l}\text { '... He toucht it; and did euery string extend / (With an exploratorie } \\
\text { spirit assaid) / To all the parts, that could on it be plaid. / It } \\
\text { sounded dreadfully; to which he sung, / As if from thence, the } \\
\text { first, and true force sprung / That fashions Virtue. God, in him did } \\
\text { sing ...' }\end{array}$ \\
\hline & & & & $\begin{array}{l}\text { Later (pp. } 77-8 \text { ), Hermes ' } . . . \text { his Lute tooke; and assaid / A song' } \\
\text { to Phoebus (also called Apollo in the text) with 'Tunes so } \\
\text { artfull clere': }\end{array}$ \\
\hline & & & & $\begin{array}{l}\text { '... O then, his voice would runn / Such points vpon his play; and } \\
\text { did so moue, / They tooke Apollo Prisoner to his loue...' }\end{array}$ \\
\hline & & & & $\begin{array}{l}\text { So 'heauenly' is his song that Hermes seems to have a 'new } \\
\text { voice; such as neuer yet came nere / }\end{array}$ \\
\hline & & & & $\begin{array}{l}\text { The brest of any; either Man, or God ... ' (page 79). He later tells } \\
\text { Phoebus (=Apollo) to 'Take thou my Lute' and 'Sing; and } \\
\text { perfection in thy song command' (pages } 80-81 \text { ). Apollo (page } \\
82 \text { ) then 'tooke / Into his left hand' his lute and 'shooke / } \\
\text { Delightsome sounds vp, to which God did sing'. }\end{array}$ \\
\hline & & & To Phoebus, 134 & $\begin{array}{l}\text { '... Thee, that thy Lute; mak'st sound so to thy Beames. / Thee, first } \\
\text { and last, the sweete-voic't singer, still / Sings; for thy songs-all- } \\
\text { songs-transcending skill ...' }\end{array}$ \\
\hline
\end{tabular}




\begin{tabular}{|c|c|c|c|c|}
\hline Doc. & Author / Title & Publisher / Year & Page / Folio & Passage / Comments \\
\hline \multirow[t]{2}{*}{71} & \multirow{2}{*}{$\begin{array}{l}\text { Anon., The Tragedy of Nero, } \\
\text { Newly Written }\end{array}$} & \multirow{2}{*}{$\begin{array}{l}\text { Augustine Mathewes and lohn } \\
\text { Norton, London, } 1624\end{array}$} & \multirow[t]{2}{*}{ Act $3,[D 4]^{r}$} & Nero: \\
\hline & & & & $\begin{array}{l}\text { 'They tell of Orpheus, when he tooke his Lute, / And moou'd the } \\
\text { noble luory with his touch: / Hebrus stood still, Pangea bow'd } \\
\text { his head, / Ossa then first shooke off his snowe, and came / To } \\
\text { listen to the moouings of his song ...' }\end{array}$ \\
\hline 72 & $\begin{array}{l}\text { John Penkethman, The } \\
\text { Epigrams Of } P \text {. Virgilivs } \\
\text { Maro, and others }\end{array}$ & $\begin{array}{l}\text { G. P. [George Purslowe], } \\
\text { London, } 1624\end{array}$ & $\begin{array}{l}\text { 9. Vpon Virgil and his workes. } \\
\text { By Sextus Propertius in his } \\
\text { 2. Booke, Elegy 24, D2 }{ }^{\mathrm{r}}-\mathrm{D} 2^{\mathrm{v}} \\
\text { (at D2 }^{\mathrm{r}} \text { ) }\end{array}$ & $\begin{array}{l}\text { Singing to the lute is implied in the description of Phoebus, who } \\
\text { 'could sing' and '... if the learned Lute he take / And play } \\
\text { thereon, such Musicke thou dost make.' }\end{array}$ \\
\hline 73 & $\begin{array}{l}\text { William Jones, } A \text { Treatise of } \\
\text { Patience in Tribulation }\end{array}$ & William Jones, London, 1625 & no. 7, pp. $41-2$ (at 42 ) & $\begin{array}{l}\text { '... It did not with thine actiue spirit suite / To wast thy time in } \\
\text { fingring of a Lute, / Or sing mong'st Cupids spirits a puling Dittie } \\
\text { / To moue some femall Saint to loue or pittie ... }\end{array}$ \\
\hline 74 & $\begin{array}{l}\text { Anon., The wofull complaint, } \\
\text { and lamentable death of } a \\
\text { forsaken Louer }\end{array}$ & $\begin{array}{l}\text { printed for Henry Gosson, } \\
\text { London, c. } 1625\end{array}$ & Broadside ballad, pt 2, v. 5 & $\begin{array}{l}\text { '... When he had bewail'd his sorrowes long, / hée tooke a Lute } \\
\text { that by him hnng, [=hung] / And on the lute he sweetly plaid, / } \\
\text { and vnto it these words he said: / O death, when will the houre } \\
\text { come, / that I haue waited on so long?' }\end{array}$ \\
\hline 75 & $\begin{array}{l}\text { George Marcelline, Vox } \\
\text { Militis: Foreshewing What } \\
\text { Perils Are Procvred Where } \\
\text { The people of this, or any } \\
\text { other kingdome liue } \\
\text { without regard of Marshall } \\
\text { discipline }\end{array}$ & $\begin{array}{l}\text { B. A. [Bernard Alsop], London, } \\
1625\end{array}$ & Pt 2, pp. 28-58 (at 31-2) & $\begin{array}{l}\text { 'And Xerxes being offended with the Babylonians, because they } \\
\text { trayterously had shrunke from him: when he had againe } \\
\text { brought them vnder, he forbad them to beare any more } \\
\text { weapons, \& further commaunded them, that they should sing } \\
\text { to the Lute, and other Instruments, learne to keepe harlots, and } \\
\text { haunt Tauernes, which policy he of purpose prepared, to } \\
\text { weaken their courages, whereby he might the better keep them } \\
\text { vnder awe.' }\end{array}$ \\
\hline
\end{tabular}

